\title{
Avaliação dos Parâmetros de Halitose Bucal e Nasal em Pacientes Com e Sem Fissura de Lábio e/ou Palato
}

\section{Flávio Monteiro Amado}

Dissertação apresentada à Faculdade de Odontologia de Bauru, da Universidade de São Paulo, como parte dos requisitos para obtenção do título de Mestre em Odontologia, área de Estomatologia. 


\title{
AVALIAÇÃO DOS PARÂMETROS DE HALITOSE \\ BUCAL E NASAL EM PACIENTES COM E SEM \\ FISSURA DE LÁBIO E/OU PALATO
}

\section{Flávio Monteiro Amado}

\author{
Dissertação apresentada à Faculdade \\ de Odontologia de Bauru, como parte \\ dos requisitos para obtenção do título \\ de Mestre em Odontologia, área de \\ Estomatologia.
}

Prof. Dr. Luiz Eduardo Montenegro Chinellato

BAURU 


\begin{tabular}{|l} 
Amado, Flávio Monteiro \\
Avaliação dos parâmetros de halitose bucal e nasal em pacientes \\
com e sem fissura de lábio e/ou palato / Flávio Monteiro Amado. \\
- Bauru, 2003. \\
xviii, 84 p. : il. ; $30 \mathrm{~cm}$. \\
Dissertação (Mestrado) - Faculdade de Odontologia de Bauru. \\
Universidade de São Paulo. \\
Orientador: Prof. Dr. Luiz Eduardo Montenegro Chinellato
\end{tabular}

Autorizo, exclusivamente para fins acadêmicos e científicos, a reprodução total ou parcial desta dissertação, por processos fotocopiadores e outros meios eletrônicos.

Bauru, 22 de maio de 2003.

Projeto de Pesquisa aprovado pelo Comitê de Ética em Pesquisa da Faculdade de Odontologia de Bauru, Universidade de São Paulo. Of.n CEP/06 2003/FOB 


\section{Flávio Monteiro Amado}

09 de novembro de 1976

Santos - SP

1994-1997

1998-2000

2001-2003

2002-
Nascimento

Filho de Carlos Roberto Passos

Amado e Julieta Vanda Monteiro

Amado

Curso de Graduação em Odontologia pela Faculdade de Odontologia de Bauru - Universidade de São Paulo

Residência em Implantodontia no Hospital de Reabilitação de Anomalias Craniofaciais - Universidade de São Paulo

Curso de Pós-Graduação em Estomatologia, ao nível de Mestrado, pela Faculdade de Odontologia de Bauru - Universidade de São Paulo Associação Brasileira de Radiologia Odontológica (ABRO) 
"Quantas pessoas já se beneficiaram do desenvolvimento da ciência?" Ismail Serageldin Abril, 5ª edição da Revista Science, 2002.

“Apesar do genoma do arroz ter sido totalmente seqüenciado, ainda existem mais de 800 milhões de pessoas sofrendo de fome". World Poverty, Hunger and Science, Yuqun Li.

"Ciência e tecnologia dominam nossas vidas. Mas muito pouca atenção é dada a como elas podem ser utilizadas para beneficiar toda a humanidade. Muito freqüentemente elas são utilizadas para enriquecer os ricos, empobrecer os pobres e comprometer o meio ambiente. Contudo, mais atenção precisa ser dada a como a ciência e tecnologia podem servir a humanidade - particularmente ciência para os pobres". Conferência do Clube de Roma, Novembro 25 - 27, 1999 Hofburg Redoutensäle Vienna, Áustria.

"Se sabiamente empregada, a ciência pode melhorar não apenas o padrão de vida, mas também melhorar a qualidade de vida". The Temper of Science, Prof. T. V. Pillai, Chairman, Peace University Committee, Padicherry.

“A prática da pesquisa científica e o uso do conhecimento desta deveriam sempre objetivar o bem-estar da humanidade, incluindo a redução da pobreza, ser respeitoso à dignidade e direitos dos seres humanos e do ambiente global, e levar completamente em consideração nossa responsabilidade frente às presentes e futuras gerações. O currículo científico deveria incluir ética em ciência". Declaração sobre ciência e o uso do conhecimento científico. UNESCO, versão adaptada adotada pela Conferência, $1^{\text {o }}$ Julho, 1999. 
"Que o valor deste trabalho não se encerre no mesmo, com a apresentação de seus resultados. Que seu mérito seja sentido no aspecto formativo, refletido em projetos relevantes". 


\section{Dedico este trabalho}

À minha mãe e mew pai, Julieta e Beto, admiradores, estimuladores, instigadores e criticos. Mais do que isso, e mais importante, são a alma de mew crescimento e de mens irmãos. $E$ esperando fazer jus a todos os sens esforços que guio os mens caminhos, e minha maior satisfação será, um dia, perceber em seus othos que correspondi às suas expectativas e me tornei uma pessoa melhor. A vocês, todo o mew amor.

Ao mew irmão, ṫnio, pelo estimulo, apoí, orientações, compreensão. Você é mew exemplo de vida, bom humor e serenidade.

Ao Júlio, mew irmão e mew advogado, um grande homem, um grande coração, pela nossa crescente amizade e muitas risadas.

Muitas saudades de vocês, e uma ponta de tristeza por não participar mais intensamente de suas vidas. 


\section{Dedico também}

À Thais, por tamanha paciência, tanta ajuda, companheirismo e amor dispensados a mim nestes dois anos. Pelas correçöes e sugestões aos mens trabalhos, principalmente este - lido e relido. Sua presença foi indispensável para mim - transformow os dias, alegrow o mew caminho e mudou mitos dos mens conceitos. A vocêtambém, o mew amor.

Ao Valter, Edna, Dona Cídinha, Seu José, Daniela e Gustavo, que sempre me trataram como parte da famítia. Obrigado pela acolhida, cuidados egrande torcida. 


\section{Agradeço}

Ao mew orientador, Prof. Luiz Eduardo Montenegro Chinellato, pela total disponibilidade nos momentos necessários, pelos esclarecimentos, peta confiança e tranqüitidade com que conduziu mens primeiros passos no campo da Estomatologia.

Ao Prof. José Humberto Damante, coordenador do curso de mestrado em Estomatologia. Um homem de grande conhecimento e ainda interessado em aprender, que com seriedade e honestidade nos guiou durante o curso.

Aos professores do curso de mestrado, Profa. Ana Lúcia Alvarez Capelloza, Profa. Izabel Regina Fischer Rubira de Bullen, e aos professores de círurgia, Prof. Eduardo SantAna, Prof. Júlio de AraújoGurgel eProf. Osny Ferreira Júnior.

A Dra. Olinda, pelos conhecimentos transmitidos com tanto desprendimento, simplicidade e humildade, e que foram indispensáveis para o inicio da realização deste trabatho.

Ao Projeto SAUDBUCAL, na pessoa do Sr. Henrique Couto, pela cessão do Halimeter ${ }^{\top M}$. 


\section{Agradeço}

À Professora e amiga Dra. Maria Lúcía Rubo de Rezende, Malu, muitas vezes uma irmã, por tudo: incentivo, conselhos, confíança, amizade e paciência. Seus ensinamentos não vêm apenas através das palavras, mas dos inúmeros exemplos de honestidade, caráter e seriedade. Sua contribuição na minha formação é muito maior do que possa imaginar.

Ao Professor Dr. João Adolfo Caldas Navarro, quem primeiro me orientou no caminho cientifico, meus agradecimentos, respeito e admiração. Seus exemplos e lições permanecem entre nós.

Ao mew amigo do peito, Rodrigo-Hermont Cançado, pela enorme ajuda na reatização deste trabalho e, principalmente, pela grande amizade, em todos os momentos.

Aos colegas do curso de mestrado, Cláudio, Fernando, Josiane, Luiz Fernando e Nicole, por toda a colaboração nos momentos importantes, e às meninas do doutorado, Flavinha, Luciana e Mariela. Alguns dos maiores aprendizados vieram de nossa convivência. A vocês, men "Muito Obrigado". 


\section{Agradeço}

À tia Dulce, pela contríbuição na correção deste trabatho e pelo incentivo. À Evelise, por participar, ajudar, aconselhar. À tia Sueli, Víctor, Guitherme, avó-Zuleica, tia Ieda, tio-Waldemar, Fabricio, Fábio, Fabiano, Fredericoe tioToni.

A Luciana, ao Edilsons e ao Matheus, grandes amigos, que acompanharam esta trajetóría desde $\sigma$ inicio, sempre com uma palaura de carinho e um sorriso.

Aos amigos Celso, Érica, Marlon (e Pedro), Nilo, Nilton e Rodrigo, companheiros em Bauru por muito tempo, e que estã presentes em muitas e boas lembranças.

Aos colegas de mestrado, pelo convívio agradável no inicio deste curso, em especial ao Anderson Pinheiro de Freitas, que se tornow um grande amigo.

À Janaina e Lucyene, peto convívio e amizade.

À Andréia, Carla, Juliana, Lu, Márío, Patrícia, Silvía, Valería e Lidiane, com quem, através da Thais, pude conviver. Obrigado pelo carinho.

À Gisele Dalben que com amizade sempre me acode quando preciso de seus conthecimentos sobre a lingua inglesa.

Ao amigo Marcus Vinicius Anselmo, pelos anos de amizade. 


\section{Agradeço}

A todos os amigos.

A Bete, do setor de Implantodontoía do HRAC, por sua amizade.

Aos funcionários, Camila Medina, Cristina Aparecida Vendimiatti dos Santos, Fernanda Aparecida Daniel, José Messias de Oliveira Fütho, Josieli Aparecida Tripodi Farinha, Ligia Ramos de Oliveira Campos, Marilia Gíão e Walderez Pereira Alves, por toda a ajuda durante estes anos de trabatho.

Aos técnicos do laboratório de bioquímica, Ovidio dos Santos Sobrinho e Thelma Lopes da Silva, pela grande ajuda.

À Dra. Lúcia Helena L. Andreattas por seus conselhos e grande contribuição ao inicio da minha profissão.

À Jutiana Ferreira e Priscila Paditha Moura, que sempre me ajudam com tanta boa vontade e profissionatismo.

Ao Sílvano Sebastião Miano, da Central de Agendamentos do HRAC, pela ajuda indispensável e emboa hora.

A todos of pacientes que participaram deste estudo, por atenderem prontamente aos mens pedidos, muitos mens amigos e colegas, muitos desconhecidos, mas sempre disponiveis e atenciosos. 


\section{Agradeço}

Aos funcionários da Biblioteca e da Póg-Graduação, em especial ao Aurélio, Gíane, Jane, Mônica, Valéría e Vera, por toda a atenção e disponibitidade com que atendem a todos.

À Díretoría da Faculdade de Odontologia de Bauru, da Universidade de SãoPauto.

À Comissão dePós-Graduação da Faculdade de Odontología de Bauru, da Universidade de SãoPauto.

Ao Centrinho, meu lar por dois anos, e que ainda hoje me emociona.

Ao Prof. José Roberto Lauris, pelas orientações quanto à análise estatistica

Aos pacientes da Clínica de Estomatologia desta Faculdade, sem os quais o aprendizado seria impensável.

A todos que colaboraram direta ou indiretamente na realização deste trabatho.

À CAPES (Coordenação de Aperfeiçoamento de Pessoal de Nivel Superior) pela concessão da bolsa de estudos. 


\section{SUMÁRIO}

LISTADE FIGURAS Xiii

LISTA DE TABELAS $\quad$ XV

LISTA DE ABREVIATURAS E SÍMBOLOS Xvi

RESUMO Xvii

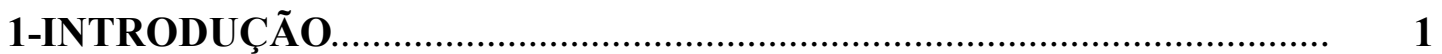

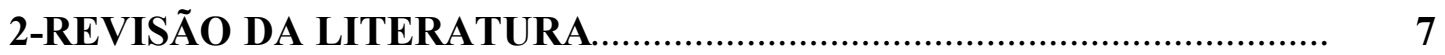

2.1-Hálito - considerações iniciais................................................................ 7

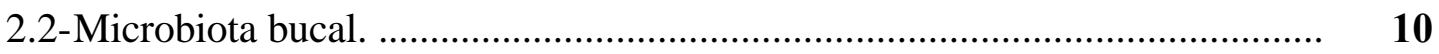

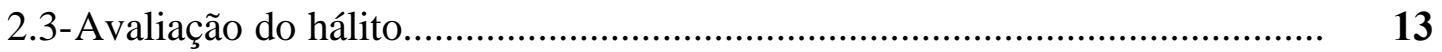

2.3.1-Avaliação organoléptica.......................................................................... 13

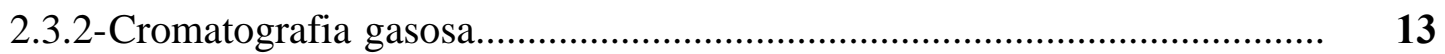

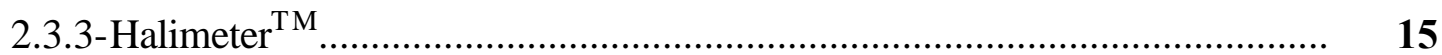

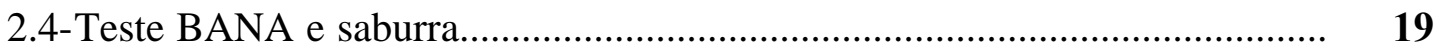

2.5-Saliva e fluxo salivar................................................................................. 23

2.6-Auto-percepção do hálito.......................................................................... 25

2.7-A fissura lábio-palatina............................................................................... 27

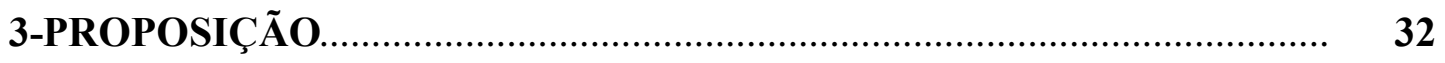

4-MATERIAL E MÉTODOS ................................................................ 34

4.1-Seleção da amostra..................................................................................... $\quad 34$

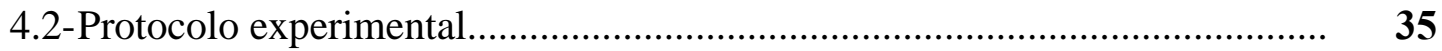

4.2.1-Orientações prévias e início da consulta...................................................... 35

4.2.2-Coleta dos valores de halimetria........................................................... 37

4.2.3-Avaliação da saburra e novas medidas de halimetria................................. 39

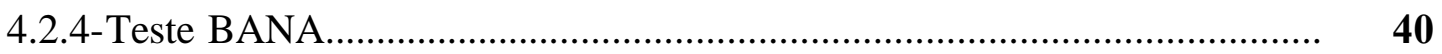

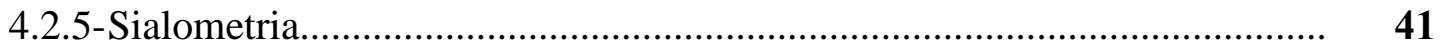

4.2.6-Questionário médico-odontológico........................................................ 42

5. RESULTADOS

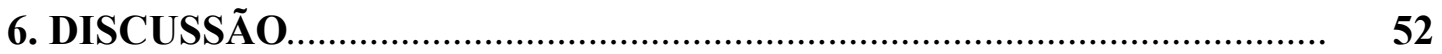

6.1-Delineamento do estudo......................................................................... 54

6.2-Seleção da amostra................................................................................... 55 


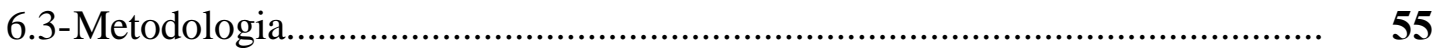

6.4-Discussão dos resultados.......................................................................... 5

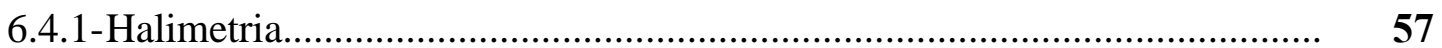

6.4.1.1-Halimetria bucal.............................................................................. $\quad 58$

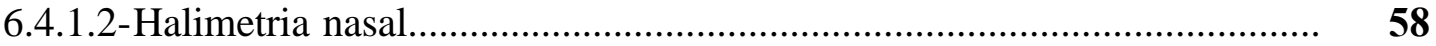

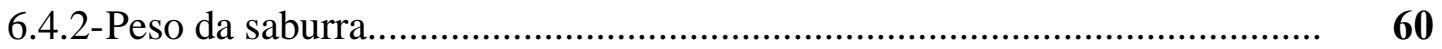

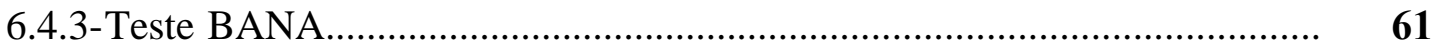

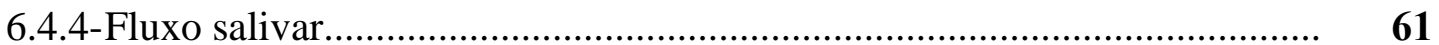

6.4.5-Auto-percepção do hálito......................................................................... $\quad \mathbf{6 2}$

6.5-Considerações finais.................................................................................. $\quad 63$

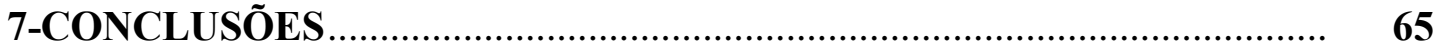

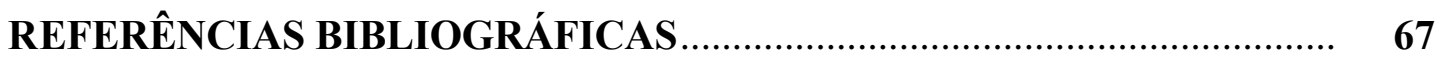

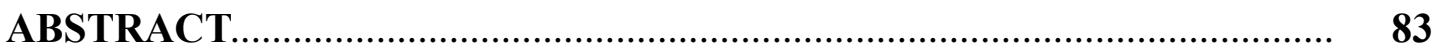

APÊNDICES 


\section{LISTA DE FIGURAS}

FIGURA 1 Diferentes tipos de fissuras de lábio e/ou palato: A) fissura de palato primário - fissura unilateral préforame incisivo incompleta; B) fissura de palato primário - fissura bilateral pré-forame incisivo completa; C) fissura de palato primário e secundário fissura unilateral transforame incisivo; D) fissura de palato primário e secundário - fissura bilateral transforame incisivo; E) fissura de palato secundário fissura pós-forame incisivo completa; F) fissura de palato secundário - úvula bífida.

FIGURA 2 Mesa de atendimento do paciente: 1) guardanapo; 2) gaze; 3 ) limpador de língua; 4) canudos; 5) papel filtro; 6) colher de dentina; 7) água destilada; 8) fita teste BANA; 9) hiperbolóide; 10) seringa para sialometria; 11) vidros para coleta de saliva.

FIGURA 3 Halimeter ${ }^{\mathrm{TM}}$

FIGURA 4 Canudo na boca do paciente para leitura da concentração dos CSVs

FIGURA 5 Registro do valor máximo no monitor do aparelho 38

FIGURA 6 Medição do valor de halimetria nasal

FIGURA 7 a) remoção do excesso de umidade da língua; b) remoção da saburra; c) colocação da saburra sobre o papel filtro; d) pesagem da saburra em balança

FIGURA 8 a) colocação da saburra na fita teste com colher de dentina;

b) colocação de água destilada na fita teste; c) dobragem da fita; d) fita presa com clipe de papel

FIGURA 9 Sialometria em repouso

FIGURA 10 a)hiperbolóide sendo colocado na boca; b) obtenção da saliva, c) medição do volume salivar 
FIGURA 11 Gráfico da correlação de Pearson entre H1 e SAB, grupo II.

FIGURA 12 Gráfico da correlação de Pearson entre H1 e SREP, grupo II.

FIGURA 13 Gráfico da correlação de Pearson entre H1 e SEST, grupo II.

FIGURA 14 Gráfico da correlação de Pearson entre SREP e $\mathrm{SAB}$, grupo II.

FIGURA 15 Gráfico da correlação de Pearson entre SEST e $\mathrm{SAB}$, grupo II

FIGURA 16 Gráfico da correlação de Pearson entre SREP e SEST, grupo II.

FIGURA 17 Gráfico da correlação de Pearson entre H1 e SAB, de todos os pacientes agrupados.

FIGURA 18 Gráfico da correlação de Pearson entre SEST e SAB, de todos os pacientes agrupados.

FIGURA 19 Gráfico da correlação de Pearson entre SEST e SREP, de todos os pacientes agrupados 


\section{LISTA DE TABELAS}

TABELA 1 Modificação da classificação das fissuras labiopalatinas $^{95}$.

TABELA 2 Resultados do teste $\mathrm{t}$ pareado para a relação entre as variáveis $\mathrm{H} 1$ e H2, e H1 e H3, do grupo I.

TABELA 3 Resultados do teste t pareado para a relação entre as variáveis $\mathrm{H} 1$ e H2, e H1 e H3, do grupo II.

TABELA 4 Resultados do teste t pareado para a relação entre as variáveis $\mathrm{H} 1$ e $\mathrm{H} 2$, e $\mathrm{H} 1$ e $\mathrm{H} 3$, de todos os pacientes agrupados.

TABELA 5 Resultados do teste t independente entre as variáveis dos grupos I e II.

TABELA 6 Resultados do teste de correlação de Pearson entre as variáveis com possíveis relações causais com a halitose, no grupo I.

TABELA 7 Resultados do teste de correlação de Pearson entre as variáveis com possíveis relações causais com a halitose, no grupo II.

TABELA 8 Resultados do teste de correlação de Pearson entre as variáveis com possíveis relações causais com a halitose, de todos os pacientes agrupados.

TABELA 9 Resultados do teste de correlação de Spearman entre H1 e BANA e $\mathrm{H} 1$ e AP, de todos os pacientes agrupados. 


\section{LISTA DE ABREVIATURAS E SÍMBOLOS}

$\%$

$\left(\mathrm{CH}_{3}\right)_{2} \mathrm{~S}$

(CH3SH)

AP

BANA

cm

$\mathrm{CO}_{2}$

CSVs

DNA

ELISA

FOB

H1

H2

$\mathrm{H}_{2} \mathrm{~S}$

H3

HB

HN

HRAC

mg

mL

pH

ppb

SAB

SEST

SREP

USP porcentagem

dimetil sulfeto

metil mercaptana

auto-percepção do hálito

benzoyl - DL - arginine - 2 napthylamide

centímetros

dióxido de carbono

compostos sulfurados voláteis

ácido desoxirribonucleico

enzyme-linked immunosorbent assay

Faculdade de Odontologia de Bauru

halimetria bucal inicial

halimetria bucal após remoção da saburra

sulfeto de hidrogênio

halimetria bucal com expiração forçada

halimetria bucal

halimetria nasal

Hospital de Reabilitação de Anomalias Craniofaciais

miligrama

mililitro

potencial de hidrogênio

partes por bilhão

peso seco da saburra

fluxo salivar estimulado

fluxo salivar em repouso

Universidade de São Paulo 


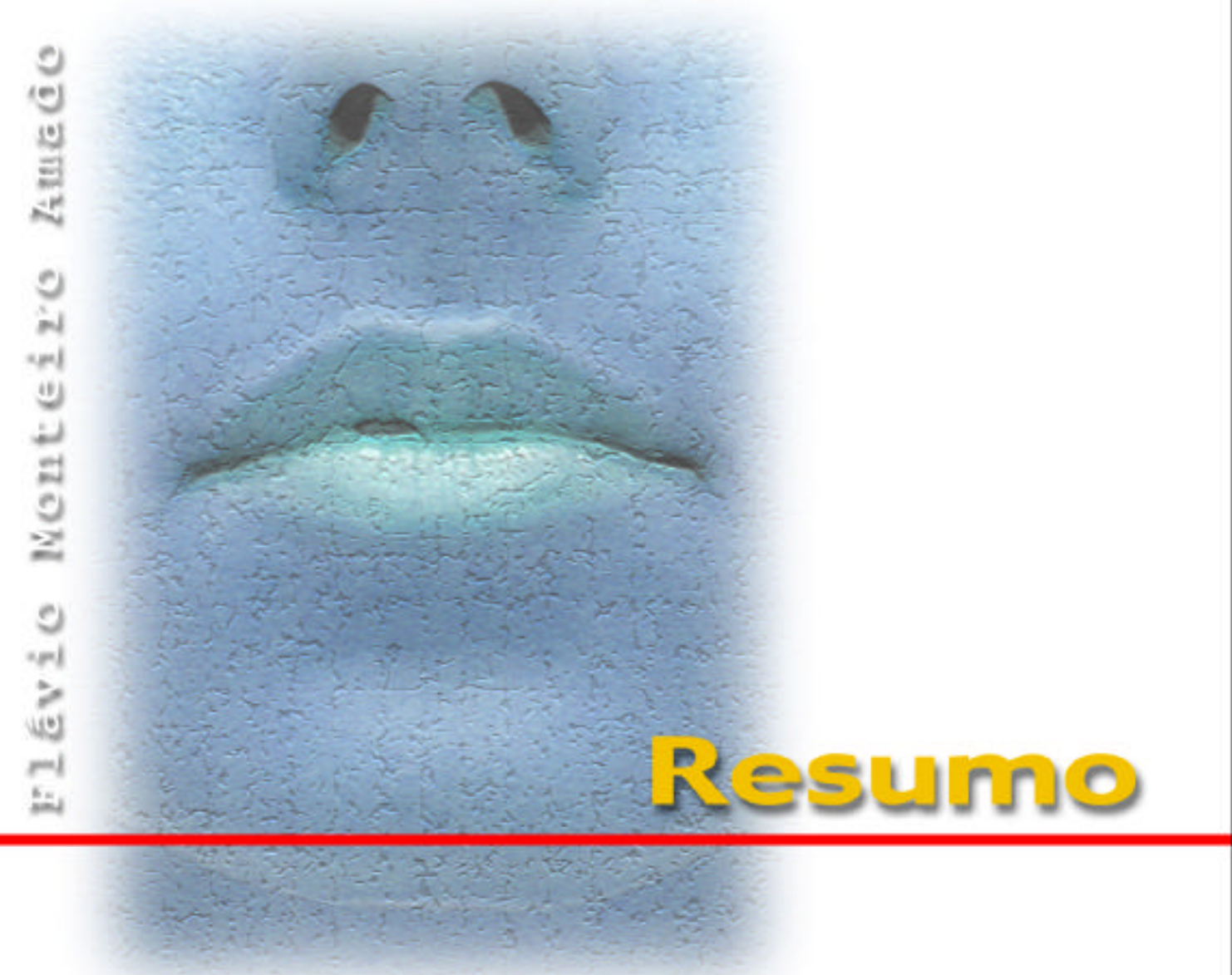




\section{RESUMO}

O objetivo deste estudo foi investigar as relações entre os parâmetros de halitose em pacientes portadores de fissura de lábio e/ou palato e alunos de pósgraduação da FOB-USP, levando-se em consideração a presença de saburra, classificada em termos de peso seco, fluxo salivar, teste BANA e halimetria nasal e bucal, e comparar os resultados entre os grupos. Foram examinados 42 pacientes divididos em dois grupos. O grupo 1 ficou constituído por alunos de pós-graduação em odontologia da FOB, sem queixa de halitose, e o grupo 2 por portadores de fissura de lábio e/ou palato já reparada, moradores da cidade de Bauru. Foram avaliadas as concentrações bucal e nasal de Compostos Sulfurados Voláteis (CSVs) através do monitor portátil de sulfetos Halimeter ${ }^{\mathrm{TM}}$, os valores relacionados à taxa de fluxo salivar em repouso e estimulado, teste BANA com material proveniente da saburra lingual e peso seco da mesma. Os resultados foram analisados utilizando-se o teste $\mathrm{t}$ dependente e independente, nas variáveis quantitativas escalares da halitose, fluxo salivar e peso da saburra; correlação de Spearman foi utilizada para avaliar a correlação entre as variáveis estudadas. Os resultados mostraram que houve relação entre a presença de saburra e os níveis de CSVs, assim como entre fluxo salivar, tanto em repouso como estimulado, com os níveis de CSVs; no grupo 2 pôde-se ainda observar relação significante entre o peso da saburra e o fluxo salivar em repouso e estimulado, e a mesma relação entre fluxo salivar estimulado e peso da saburra após o agrupamento dos pacientes em um único grupo; não houve diferença significante entre os grupos em relação à halimetria bucal; o grupo 1 apresentou maiores valores de halimetria nasal do que o grupo 2; não houve relação entre os níveis de CSVs e a percepção do paciente sobre seu hálito. Conclusão: os pacientes com fissura de lábio e/ou palato operados não mostraram diferenças significantes em relação aos parâmetros estudados, quando comparados com pacientes sem fissura. 
"Oientida humano de cheiro épobremente desenualuido comparada a maiovia das mamiferos e insedos.

- Oppesar disto, ainda émuito sensiúd no humano e é quase

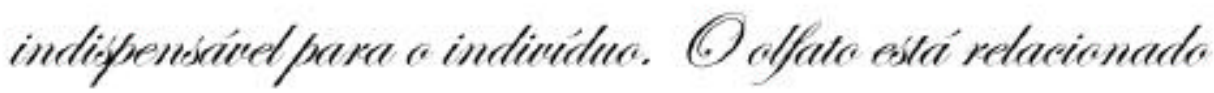
a protesna da pessoa, interfere no estado psicoligica do

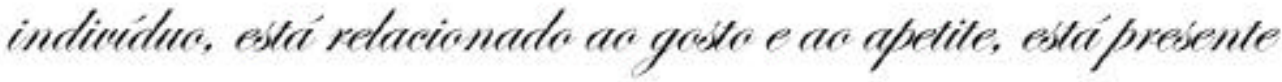
em alyumas canpascies e interage com extimulas seanais".

\section{Stryung Ofhill OSthe}

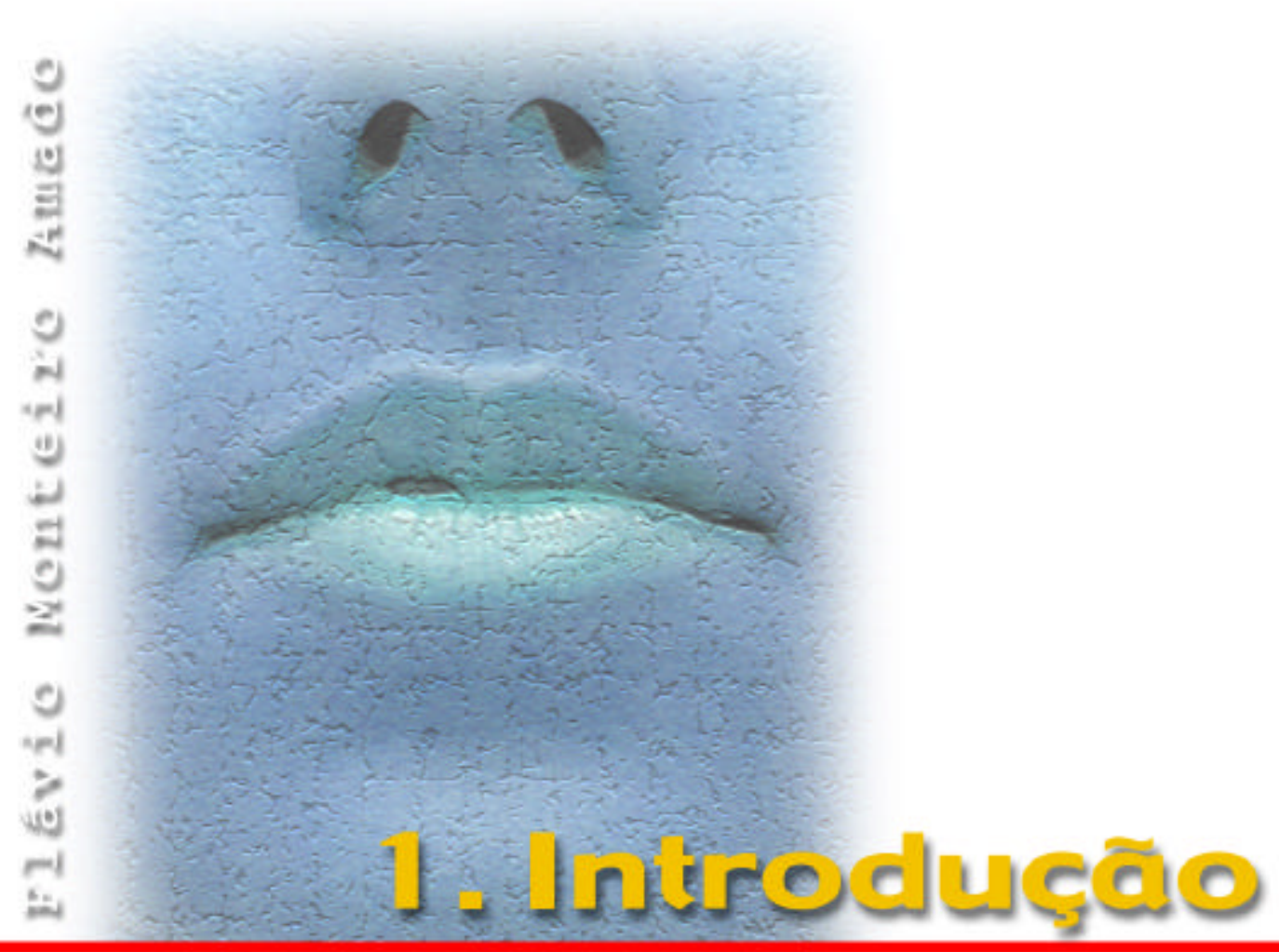




\section{1-INTRODUÇÃO}

A relação da boca com doenças sistêmicas é um fato, e vem sendo abordada cada vez com mais frequiência na literatura mundial. Há relatos de que a microbiota presente na boca influencie a instalação e progressão de doença gástrica ${ }^{113}$ e periodontal. Esta, ocasionalmente, pode ser o fator causal de certas patologias vasculares, com possíveis conseqüências cardíacas e cerebrais ${ }^{107}$, parto prematuro e pneumonia 96 .

Em culturas primitivas, a limpeza bucal freqüentemente possuía significado religioso. O budismo, o hinduismo e o islamismo pregam a limpeza meticulosa da boca e língua. Contudo, a limpeza da língua é uma prática ainda pouco difundida no ocidente e pouco apreciada pelo público, a despeito de ser instruída há séculos 24 .

A língua é um dos maiores sítios de acúmulo bacteriano na boca 112 , visto que sua grande área e estrutura papilar retém muita saburra, que é constituída de matéria orgânica depositada sobre a língua, incluindo células descamadas, leucócitos mortos e restos alimentares, onde há uma extensa população microbiana ${ }^{57}$ que, dependendo de sua composição, pode levar a alterações no hálito5, 12, 31, 42, 61, 69, 72, 91,103

Halitose é uma palavra proveniente do latim halitus, onde halitos significa "ar expirado" e osis se refere a uma alteração patológica ${ }^{28}$. Pode trazer prejuízos à saúde física e psicológica dos indivíduos, podendo limitar contatos sociais ${ }^{13}$. $\mathrm{O}$ fato de as pessoas possuírem ou imaginarem possuir halitose fez surgir uma variedade de produtos para oferecer tratamento ao problema.

A etiologia da halitose é variada, e inclui situações fisiológicas e patológicas, podendo ser dividida nas seguintes categorias: (1) devida a fatores locais de origem patológica, (2) devida a fatores locais de origem não patológica, (3) devida a fatores sistêmicos de origem patológica, (4) devida a fatores sistêmicos de origem não- 
patológica, (5) devida à administração sistêmica de drogas, (6) devida a xerostomia 34.

Os gases responsáveis pelo odor fétido expirado são, na grande maioria dos casos, os Compostos Sulfurados Voláteis (CSVs), como sulfeto de hidrogênio $\left(\mathrm{H}_{2} \mathrm{~S}\right)$, dimetil sulfeto $\left(\mathrm{CH}_{3}\right)_{2} \mathrm{~S}$ e metil mercaptana $\left(\mathrm{CH}_{3} \mathrm{SH}\right)$, que contém enxofre em sua composição, e são resultado da degradação de aminoácidos sulfurados, como metionina e cisteína, componentes estruturais de membranas celulares, ou presentes em alguns alimentos $82,83,86,114$.

Embora diversos sejam os microorganismos capazes de realizar o processo de produção dos CSVs, os maiores produtores destes gases são o Treponema denticola, Porphyromonas gingivalis, Prevotella intermédia, Bacteróides forsythus e Fusobacterium. Destes, três em especial - T. denticola, P. gingivalis e B. forsythus produzem uma enzima "trypsinlike" que pode ser detectada pela hidrólise do peptídeo sintético benzoyl-DL-arginin-2-napthylamide, chamado de BANA, que pode ser monitorada por um kit disponível no comércio denominado teste BANA $^{\mathrm{TM}_{31}}$. Utilizando como substrato material estagnado em diversas regiões da boca, este teste pode verificar a presença ou não de microorganismos BANA positivos, isto é, que degradam o composto sintético.

No caso da halitose, o interesse especial é a avaliação da saburra, visto que o epitélio descamado depositado sobre a língua oferece um ambiente ideal para a deposição de pequenas partículas alimentares, células descamadas e bactérias capazes de degradar estes componentes e emitir odor fétido ${ }^{12}$.

Diversos são os fatores que podem levar a uma maior descamação do epitélio bucal, como alterações no ciclo menstrual ${ }^{51}$, irritação causada por detergentes

\footnotetext{
* Konwell Therapeutic Tecnologies, Inc.
} 
presentes nos dentifrícios $50,52,88$, respiração bucal, trauma na mucosa jugal e utilização de aparelhos protéticos e ortodônticos*.

A higiene bucal deficiente é provavelmente o fator mais comum que leva ao mau-hálito, e tende a exacerbar outras causas ${ }^{130}$. Aproximadamente $90 \%$ dos casos de halitose têm origem na boca ${ }^{112}$, sendo que a saburra lingual possui uma correlação direta com os níveis de $\mathrm{CSVs}^{23}, 25,31,61,70,72,91$, podendo ser responsável por aproximadamente 50\% dos CSVs produzidos na boca, quer em indivíduos saudáveis ou que apresentem doença periodontal ${ }^{129}$. O monitoramento da presença de microorganismos na saburra pelo teste BANA pode ser um importante aliado de diagnóstico e controle da halitose.

Três são os principais métodos para avaliação do odor exalado: organoléptico, na qual, resumidamente, avaliadores de odor cheiram o ar expirado pelo paciente e o caracterizam em escala de 0 a 4 ou 0 a 5; cromatografia gasosa, onde se utiliza o cromatógrafo gasoso para identificar e quantificar os gases constituintes do ar expirado; e também monitor portátil de sulfetos, que puxa o ar da boca do paciente através de um canudo e avalia a presença de CSVs em partes por bilhão (ppb) ${ }^{86}$. Apesar de oferecer o método mais preciso na detecção dos gases responsáveis pelo mau-hálito, o acesso difícil ao cromatógrafo gasoso e a inviabilidade de sua utilização clínica levam à necessidade do uso de métodos diagnósticos mais simples, como é o caso do monitor de sulfetos Halimeter ${ }^{\mathrm{TM} * *}$, que por ser portátil e de fácil manuseio está gradualmente sendo introduzido em clínicas odontológicas.

Muita ênfase é dada na literatura para o hálito desagradável gerado na boca, mas poucos são os relatos sobre o mau cheiro gerado por alterações nasais 8,12 , ainda mais quando cirurgiões-dentistas 26,112 e médicos 112 ignoram muitas vezes a etiologia e tratamento da halitose.

\footnotetext{
* TARZIA, O. Comunicação pessoal.

** Interscan Corp., Chatsworth, CA, USA.
} 
As vias aéreas são a $2^{a}$ maior causa de halitose ${ }^{32}$. Tonsilite, rinite e sinusite podem contribuir para a halitose ${ }^{53}$, além de pólipos e corpos estranhos nas vias aéreas ${ }^{14}$. CROHN; DROSD29, em 1941, afirmaram que “A menos que existam condições patológicas bucais ou nasofaringeanas, a boca, os dentes, a faringe ou o estômago exercem um pequeno ou nenhum papel na produção da halitose essencial'.

As vias nasais predominam entre as etiologias não bucais do mau-hálito. $\mathrm{O}$ odor nasal pode ser indicativo de infecção nasal, como sinusite, ou de problemas que afetam o fluxo aéreo ou secreção de muco ${ }^{84}$, e a remoção de adenóides e amídalas já foi inclusive proposta para o tratamento da halitose $\mathrm{e}^{30}$.

A fissura lábio-palatal é uma malformação congênita que ocorre em aproximadamente 1 a cada 650 nascimentos (Bauru-São Paulo) ${ }^{21}$. É uma doença multifatorial que tem como principais causas a radiação ionizante, o tabagismo, alcoolismo, idade avançada dos pais, drogas, deficiências nutricionais e mutações genéticas $^{22}$.

FILKENSTEIN ${ }^{41}$, em 1995, descreveu diversos fatores que podem levar à alta incidência de sinusite em pacientes fissurados, e, por conseguinte, o aumento da freqüência de halitose nestes pacientes. Tais fatores podem ser: desvio de septo nasal; atresia ou estenose de coanas; atresia das narinas; incompetência velofaríngea, entre outros. Pode ocorrer ainda a contaminação da cavidade nasal por saliva e comida que passa da cavidade bucal para a nasal através de fístula oro-nasal.

Em estudo prévio*, contudo, observamos que alguns pacientes portadores de fissura lábio-palatal possuiam alterações nos valores de halimetria nasal em pelo menos uma das narinas, o que não foi observado em pacientes não-fissurados, levando-nos ao desenvolvimento desta investigação. Nosso intuito será avaliar os parâmetros de halitose bucal e nasal em pacientes portadores e não portadores de

\footnotetext{
* AMADO, F. M. et al. Faculdade de Odontologia de Bauru/Departamento de Estomatologia - USP. /Trabalho em andamento/
} 
fissura de lábio e/ou palato, para que possamos ter condições de prevenir e tratar a halitose nestes pacientes. 


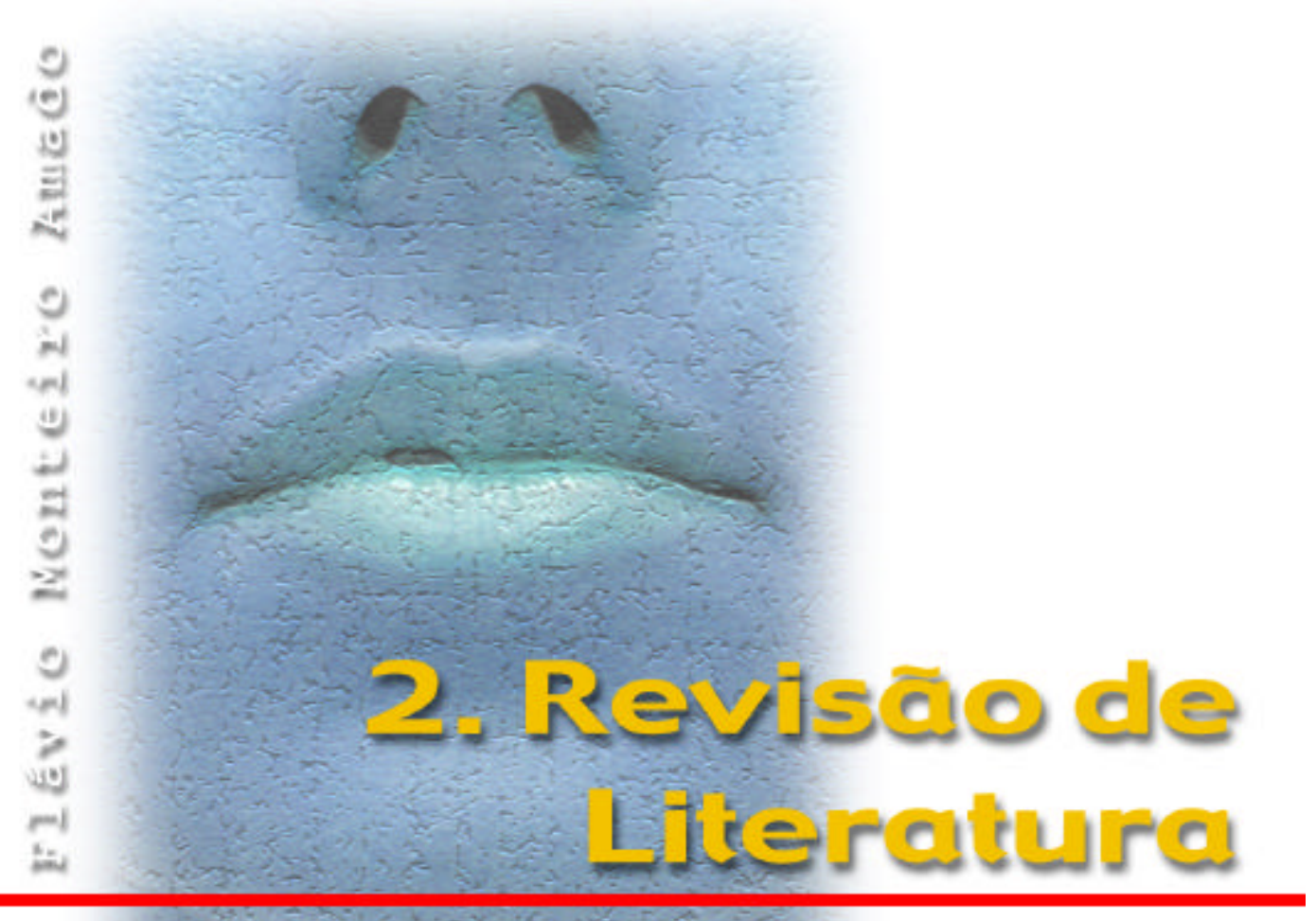




\section{REVISÃO DE LITERATURA}

A halitose é uma condição afetada por vários fatores interdependentes, como fluxo salivar, flora bucal gram-negativa, $\mathrm{pH}$ bucal alcalino, presença de detritos celulares e alimentares 12,114 . É improvável, então, a apresentação deste tema apenas de forma cronológica ou separada, simplesmente, pelos assuntos que o compõe. Muitas vezes os assuntos serão abordados simultaneamente, ainda que tenha sido realizada uma divisão didática do assunto, e determinados pontos voltarão à discussão conforme se dá a evolução desta revisão da literatura. Se determinado assunto for abordado, mas não totalmente elucidado, certamente o será posteriormente, no tópico adequado.

\subsection{Hálito - considerações iniciais}

Halitose é um termo genérico que denota mauthálito proveniente de causas fisiológicas e patológicas, tanto bucais como sistêmicas, e apesar de afligir a humanidade desde gerações ancestrais ${ }^{110}$, somente quando foi estudada e descrita por HOWE108, em 1874, é que passou a ser considerada uma entidade clínica.

Como geralmente o hálito é emitido pela boca, ele é misturado e contaminado por compostos voláteis mau cheirosos que emanam da cavidade bucal. Então, o mau cheiro bucal se torna um componente contribuinte ou freqüentemente dominante do hálito ofensivo. ${ }^{114}$.

Entretanto existem muitos relatos na literatura associando a halitose às mais variadas causas como, estenose pilórica ${ }^{120}$, fibroma ${ }^{11}$, corpo estranho na cavidade nasal $^{8}$, gengivite, saburra $25,31,45,72,91,114,129$, doença periodontal, diabetes, falência hepática, infecção ou neoplasia no trato respiratório ${ }^{35}$, ou abscesso subfrênico ${ }^{15}$.

TYDD \& DYER ${ }^{120}$, em 1974, apresentaram dois casos de pacientes com halitose devida à estenose pilórica: uma mulher de 47 anos com história de doença de 
Crohn com envolvimento difuso jejunoileal, e um homen, 67 anos, se apresentou com história de 18 meses de halitose e flatulência desagradável com sintomas de flatulência acompanhada de ruídos epigástricos e queixa de que seu hálito cheirava a ovos podres.

BLOCK; HOUSTON ${ }^{11}$ apresentaram em 1987 um caso de um paciente de 33 anos, gênero feminino, que se apresentou para um exame odontológico rotineiro, com a única queixa de halitose persistente e gosto ruim, e o exame intrabucal revelou a presença de um fibroma.

BENNET $^{8}$ relatou, em 1988, um caso de halitose devida à presença de um corpo estranho na cavidade nasal de uma menina de 6 anos que havia se submetido a adenotonsilectomia; 18 meses antes foi admitida rotineiramente para a inserção de tubos de timpanostomia devido a otite média secretora persistente. Ao questionamento, contudo, seu maior problema era halitose de 5 anos de duração. Exame radiográfico para seios maxilares mostrou, contudo, a presença de um grande corpo redondo radiopaco, que na cirurgia demonstrou ser um irrigador de $1.5 \mathrm{~cm}$ severamente corroído, firmemente impactado no lado esquerdo do nariz. A paciente passou por cirurgia, e o pós-operatório se deu sem intercorrências, com resolução da halitose.

DURHAM; MALLOY; HODGES ${ }^{35}$, em 1993, relataram as fontes mais comuns, bucais e não-bucais, de halitose, para melhor compreensão diagnóstica. Observaram que a halitose pode refletir condições locais ou sistêmicas sérias como gengivite, doença periodontal, diabetes, falência hepática, infecção ou neoplasia no trato respiratório, e que é importante determinar principalmente se a fonte de odor é bucal ou não, e que a qualidade do odor pode ajudar nesta determinação.

Em 1998, BOYCE; COBB ${ }^{15}$ mostram um caso de um homen de 48 anos que se apresentou 4 anos antes com halitose e desconforto subcostal, que tinha como causa um abscesso subfrênico que se comunicava com o estômago. $\mathrm{O}$ paciente havia 
passado por uma esplenectomia 10 anos antes por púrpura trombocitopênica idiopática, e em uma gastroscopia foi encontrado pus em seu estômago.

IWAKURA et al. ${ }^{55}$, em 1994, descreveram a diversidade de características clínicas da halitose, demonstradas em dois grupos de pacientes com queixas primárias (onde halitose era a principal queixa do paciente) e secundárias (quando o paciente procurou tratamento devido a outros problemas bucais) de halitose. Sessenta e oito pacientes da Clínica de Halitose do Departamento de Odontologia Preventiva, da Tohoku University, Faculdade de Odontologia, Sendai, Japão, formaram o grupo de pacientes com halitose primária (grupo 1), e 19 pacientes encaminhados à Clínica Geral pelo Departamento de Diagnóstico Bucal e Radiologia Bucal, para vários tratamentos formaram o grupo com halitose secundária (grupo 2). Foi realizado questionário sobre queixa de halitose e exame organoléptico. Todos os pacientes foram tratados até que o mau hálito, se presente, se tornasse indetectável ao exame organoléptico. Vinte e cinco por cento dos pacientes do grupo 1 realmente possuíam halitose, contra 52,6\% do grupo 2. A principal motivação dos pacientes do grupo 1 para a visita profissional foi a consciência do hálito baseada na atitude de outras pessoas $(48,5 \%)$. No grupo 2 foi a indicação da halitose por outros $(52,6 \%)$. Aproximadamente metade dos pacientes do grupo 1 (52,9\%) já havia visitado outras clínicas para tentar solucionar o problema, contra nenhum paciente do grupo 2. Os pacientes mais propensos a não se satisfazerem com o tratamento foram os do grupo 1, mas que não apresentavam halitose.

\subsection{Microbiota bucal}

Oitenta a noventa por cento de todos os odores do mau-hálito se originam da boca e são causados por bactérias ${ }^{60}$. Alguns requisitos para que ocorra o mau-hálito são a presença de bactérias anaeróbias, baixo nível de oxigênio, $\mathrm{pH}$ alcalino salivar e substratos que contenham enxofre 12,114 .

Mc NAMARA et al. ${ }^{69}$, em 1972, investigaram o papel de microorganismos bucais na produção do hálito. Realizaram experimentos in vitro com saliva incubada, 
caldo de microorganismos incubado com saliva, e culturas de microorganismos selecionados, e avaliadores de odor caracterizaram a presença ou não de odor putrefeito. Os autores puderam observar uma relação positiva de causa e efeito entre a presença de microorganismos salivares e produção de mau cheiro, sendo que amostras livres de bactérias não produziram cheiro. Das 14 espécies de microorganismos utilizados, nenhum gram-positivo gerou odor fétido, sendo que as espécies que originaram odor desagradável foram as espécies gram-negativas Leptotrichia sp., Fusobacterium polimorphum, Veillonellafundiliformis, Bacteróides fundiliformis e Klebsiella pneumoniae. Foi observado ainda que em amostras com o $\mathrm{pH}$ mais alto, o odor gerado foi mais desagradável, e que a adição de glicose à saliva incubada suprimiu a formação de odor.

Tonzetich foi um dos pioneiros na pesquisa da halitose, a quem se atribui o crédito pelos primeiros estudos científicos buscando as causas da halitose. Foi ele quem descreveu os vários fatores clínicos relacionados com o mau odor bucal, e iniciou pesquisas sobre os compostos sulfurados voláteis CSVs ${ }^{121}$. Em um de seus estudos 116 relatou que os CSVs não são apenas um produto da doença periodontal, mas que $\mathrm{o}_{2} \mathrm{~S}$ (sulfeto de hidrogênio) reage com o colágeno do periodonto, podendo alterar a estrutura protéica, tornando o ligamento periodontal e tecido ósseo mais susceptíveis à destruição por proteases, evidenciando que os CSVs podem ser fatores agravantes da doença periodontal.

O mesmo autor 115, em 1978, relatou que substâncias celulares oferecem o substrato protéico requerido para a degradação em CSVs por microorganismos, e afirmou também que a intensidade do odor e a quantidade de CSVs são aumentadas no ar da boca de indivíduos com condições inflamatórias bucais, sendo que os odores fisiológicos normais são menos intensos, transitórios e geralmente respondem às práticas tradicionais de higiene bucal.

Tentou-se estabelecer uma relação entre halitose e infecção por Helicobacter pylori quando TYOMNI et al. ${ }^{113}$, em 1992, acompanharam 3 casais nos quais um dos membros, ou ambos, tinha halitose, onde esta era evidente para os membros da 
família, médicos clínicos e gastroenterologistas. Cinco dos seis pacientes foram submetidos a endoscopia devido a queixas de estufamento, náusea e inchaço no trato superior gastrointestinal, sendo que os cinco pacientes possuíam gastrite e evidências histológicas de infecção por Helicobacter pylori. Os indivíduos receberam tratamento de 4 semanas composto por 1 tablete de De-Nol (subcitrato de bismuto coloidal) 4 vezes por dia e $250 \mathrm{mg}$ de metronidazol três vezes ao dia. Três dos pacientes relataram que houve desaparecimento da halitose juntamente com grande melhora das queixas gastrointestinais. Também os mesmos observadores da família e grupo médico observaram desaparecimento da halitose em todos os pacientes exceto em um. Um curso terapêutico adicional erradicou a bactéria e halitose. Os autores relatam que a possível conexão entre halitose e infecção por $H$. pylori é uma observação preliminar deste estudo piloto, mas que é improvável que halitose e $H$. pylori sempre coexistam.

GOLDBERG et al. ${ }^{47}$, em 1997, mostraram relação entre a presença de Enterobacteriaceae e a produção de mau hálito. Os autores isolaram espécies de enterobactérias na saliva, bolsas periodontais e língua, e após crescimento in vitro, houve produção de mau cheiro. As bactérias estudadas demonstraram ainda grande capacidade de aderência ao polímero de dentaduras, demonstrando a produção de mau cheiro característico.

SCULLY \& PORTER ${ }^{89}$, em 1999, relataram que sepsia bucal é a causa mais freqüente de halitose. Grandes causas de halitose e gosto ruim incluem fumo e ingestão de diversos alimentos. Infecção sinusal ou de outras partes do sistema respiratório também podem ser responsáveis. Algumas doenças sistêmicas como diabetes podem dar cheiro ao hálito. A detecção da halitose geralmente é subjetiva, e a condução do problema se dá com: tratamento das causas, alimentação freqüente, evitar fumar ou comer determinados alimentos, melhoria da higiene bucal, uso de bochechos com clorexidina e cloreto de cetilpiridíneo, mastigação de chicletes e uso de preparações. 


\subsection{Avaliação do hálito}

\subsubsection{Avaliação organoléptica}

A aspiração direta do ar bucal é tida como a forma mais simples e comumente utilizada para medir o mau hálito. É geralmente referida como avaliação "hedônica" ou "organoléptica", e pode ser considerada um tipo de padrão referencial na medida da halitose, visto que esta abordagem simula de maneira bem aproximada as situações diárias nas quais o mau-hálito é detectado ${ }^{85}$.Contudo, apesar de ser considerada o meio mais simples e confiável para avaliar a halitose ${ }^{14}$, é de difícil reprodução, já que indivíduos respondem de forma diferente aos vários componentes do mauthálito. Além disso, se as pessoas se adaptam ao seu próprio odor, juízes com odor acima de um patamar determinado talvez devessem ser excluídos de estudo sobre halitose 85 .

\subsubsection{Cromatografia gasosa}

Pesquisadores em um variado número de campos científicos têm usado a cromatografia gasosa como meio de identificação dos gases encontrados nas amostras estudadas. Igualmente, cromatografia gasosa tem sido utilizada por dentistas e em estudos sobre o mauthálito, e tem oferecido um meio pelo qual o pesquisador pode definitivamente quantificar os níveis precisos de compostos específicos presentes no hálito de um indivíduo. Enquanto que a cromatografia gasosa é provavelmente o melhor meio para testar os compostos associados com a halitose, ela não tem sido largamente utilizada em estudos por diversas razões. Cromatógrafos gasosos são relativamente caros e precisam de treinamento especial para operá-los. O equipamento não é portátil e um tempo significante é necessário para fazer cada medição do hálito ${ }^{122}$. 
Embora não seja objeto deste estudo, considerou-se adequada a inclusão de alguns relatos sobre o uso da cromatografia gasosa na avaliação do hálito, pois tal metodologia é frequientemente comparada ao uso do Halimeter ${ }^{\mathrm{TM}}$.

SUAREZ et al. ${ }^{103}$ estudaram a variaçăo na concentraçăo de gases sulfurados em individuos após acordarem, e determinaram os efeitos de diferentes intervenções na concentraçấo destes gases. Através da análise pela cromatografia gasosa observaram os efeitos de tratamento a longo prazo (até 8 horas), medindo de hora em hora a concentração dos gases $\mathrm{H}_{2} \mathrm{~S}, \mathrm{CH}_{3} \mathrm{SH}, \mathrm{CH}_{3} \mathrm{SCH}_{3}$, quando as intervençōes cram: nenhuma, escovação dental por 2 minutos, escovaçẫo da lingua por 1 minuto com água, bochecho por 1 minuto com $\mathrm{H}_{2} \mathrm{O}_{2} 3 \%$, consumo de café-da-manhä habitual do paciente, ingestäo de 2 Breath $\Lambda$ sure ${ }^{\mathrm{TM}}$ (BreathAsure é uma cápsula que contèm óleos naturais, como oleo de girassoly $)^{44}$. Para a avaliação em curto prazo, com amostras do hálito obtidas com 5 minutos e 1 hora após a intervençấo, os tratamentos foram: nenhum, beber $120 \mathrm{ml}$ de água, bochecho com $5 \mathrm{ml}$ de suco de limão, ingestâo de pẳ consistente com aproximadamente 40 gramas. Os resultados mostraram que as melhores respostas foram obtidas com bochecho com $\mathrm{H}_{2} \mathrm{O}_{2}$ e escovação da lingua para reduçâo dos gases sullurados $\mathrm{cm}$ longo prazo (o que evidenciou o papel da saburra na formaçâo do mau-hálito) e através do consumo de pão na avaliação por curto periodo. Os piores resultados foram com a escovação dental e consumo de BreathAsure ${ }^{\mathrm{TM}}$, em longo prazo, e com ingestão de água ou bochecho com suco de limão, a curto prazo.

OHO et al, ${ }^{76}$, em 2001 , determinaram o nivel de mau-hálito em pacientes com queixa de halitose através do uso de diversos métodos, incluindo cromatografia gasosa, monitor portátil de sulfetos e método organoléptico. Foram examinados 155 pacientes, com idade média de 46 anos, que reclamavam de halitose que persistia por meses ou anos, sendo que alguns deles tinham seus problemas relatados por terceiros, e outros acreditavam possuir halitose devido a atitude de outras pessoas. $O$ grau de halitose foi avaliado pelo método organoléptico. O nivel de CSVs foi quantificado com cromatografia gasosa e monitor de sulfetos Halimeter ${ }^{\mathrm{TM}}$. $\mathrm{O}$ exame do hálito foi 2 a 3 horas após o café da manhã, conduzido por três juízes e avaliado de 0 a 3. A porcentagem de acerto entre os três juizes foi de $83 \%$. Foi utilizado o cromatógrafo por gás Shimadzu GC-14B (Shimadzu, Kyoto, Japão) com sistema de 
cromatógrafo por gás Shimadzu GC-14B (Shimadzu, Kyoto, Japão) com sistema de detector fotométrico. Foi também avaliada a área e espessura da saburra por inspeção, com escore de 0 a 3 para área e 0 a 2 para espessura. O fluxo salivar não estimulado foi avaliado através da expectoração da saliva por 5 minutos, expresso em volume por minuto. Houve correlação significante entre os três métodos de avaliação utilizados. Uma correlação ainda maior foi verificada entre a cromatografia gasosa e o monitor de sulfetos. Concluíram os autores que houve significantemente mais saburra nos indivíduos com alto grau de halitose, enquanto que o fluxo salivar não demonstrou ser significativo para a determinação da halitose.

SPRINGFIELD et al. ${ }^{98}$, em 2001, demonstraram que a variabilidade na concentração de CSVs obtida de indivíduos em condições controladas se deve a mudanças biológicas na boca, e não a produto de artefato na coleta ou análise dos dados. Doze voluntários saudáveis tiveram o ar bucal coletado de forma padronizada; as variações minuto a minuto nas concentrações de metil mercaptana, dimetil sulfeto e sulfeto de hidrogênio foram avaliadas e comparadas com as variações nas concentrações de dióxido de carbono $\left(\mathrm{CO}_{2}\right)$, visto que esta deveria ser constante por representar níveis sanguíneos da pressão parcial de $\mathrm{CO}_{2}$. Enquanto que as concentrações de CSVs variaram enormemente entre indivíduos e entre as coletas do mesmo indivíduo, as concentrações de $\mathrm{CO}_{2}$ mantiveram-se próximas mesmo entre diferentes indivíduos.

\subsubsection{Halimeter ${ }^{\mathrm{TM}}$}

O Halimeter ${ }^{\mathrm{TM}}$ é um monitor de sulfidretos que vem sendo utilizado para medir a quantidade de compostos sulfurados voláteis na avaliação do hálito. É um aparelho portátil, com fácil utilização clínica e se tem mostrado confiável em suas análises ${ }^{61,126 .}$

De acordo com o fabricante, níveis normais de hálito estão em torno de 150 ppb, sendo aceitável como nível normal medições entre 50 e 170 ppb. O "zero" no aparelho deve ser ajustado em ambiente livre de substâncias voláteis, e painel de 
leitura deve indicar " 0 "; caso contrário, deve ser ajustado manualmente. É aceito que o "zero" se encontre na faixa de -10 a +10 . Lê-se também no manual que mesmo com procedimento de coleta correto, podem existir grandes diferenças nas leituras de um mesmo indivíduo em um mesmo período, e também em momentos diferentes do dia. Devem ser tomadas 3 leituras e realizada a média, e que aproximadamente $90 \%$ das leituras são reproduzíveis com +/- 15 ppb, e aproximadamente 75\% das leituras são reproduzíveis com +/- 10 ppb.

ROSENBERG et al.86, em 1991, compararam a reprodutibilidade e sensibilidade de métodos organolépticos para a avaliação do mauthálito e avaliação com um monitor de sulfidretos pelo Halimeter ${ }^{\mathrm{TM}}$. Foram avaliadas 42 pessoas com queixa de mau-hálito, sem critérios de exclusão. Os indivíduos abstiveram-se de comer, beber, mastigar, chupar e bochechar por pelo menos duas horas antes da consulta. Para medir a sensibilidade do método quanto a mudanças no hálito, os pacientes foram instruídos a bochechar duas vezes por dia gluconato de clorexidina 0,2\%. Cada tratamento consistia de 2 bochechos consecutivos de 30 segundos, evitando beber ou comer por pelo menos 30 minutos depois. A avaliação do hálito foi feita através de dois métodos distintos. No primeiro foi utilizado o Halimeter ${ }^{\mathrm{TM}}$, e no segundo foi utilizada a avaliação organoléptica feita por dois juizes, que deram valores de 0 a 5. Foram feitas medidas do índice de placa e índice gengival em cada consulta, após a avaliação do hálito, e também fi feita a medida das bolsas. Os autores chegaram à conclusão que houve confiabilidade de valores entre a primeira e segunda consultas, assim como sensibilidade do aparelho quanto aos valores reduzidos de CSVs resultantes do tratamento com clorexidina.

KOZLOVSKY et al. ${ }^{61}$, em 1994, examinaram a relação entre a presença de microorganismos periodontopatogênicos na placa dental, material proveniente do dorso lingual e saliva, medidos através do teste $\mathrm{BANA}^{\mathrm{TM}}$, e avaliações organoléptica e instrumental do hálito, através do monitor portátil de sulfidretos Halimeter $^{\mathrm{TM}}$. Estudaram 52 pacientes, com idades entre 11 e 63 anos. Os participantes receberam escores quanto ao acúmulo de placa e saúde gengival para todas as superfícies dentais. Foram anotados ainda as profundidades de sondagem no segundo e terceiro 
dias do estudo com uma sonda Michigan $\mathrm{O}$, em seis pontos de referência das superfícies vestibulares e linguais de cada dente. Os resultados mostraram associação entre o teste $\mathrm{BANA}^{\mathrm{TM}}$ e parâmetros periodontais. Contudo, os valores do $\mathrm{BANA}^{\mathrm{TM}}$, em muitos casos, demonstraram associação com os valores organolépticos, mas uma fraca relação com os valores de CSVs. Possivelmente, de acordo com os autores, micro-organismos associados com o BANA ${ }^{\mathrm{TM}}$ contribuam para a formação de outras substâncias odoríferas, que não os sulfidretos (CSVs).

GOLDBERG et al. ${ }^{47}$ estudaram a produção de odor pela Klebsiella e espécies relacionadas, utilizando para isto 4 populações de indivíduos (portadores de próteses totais, pacientes ortodônticos, indivíduos dentados em atendimento em clínica de mau hálito e população jovem saudável), que foram testados para prevalência de enterobactérias bucais e níveis de mau hálito. Os autores obtiveram resultados, mostrando que espécies de enterobactérias foram isoladas de amostras obtidas de saliva, bolsas periodontais e dorso da língua, incubadas para investigação da halitose. Observaram também que as amostras de enterobactérias produziram odores desagradáveis após crescimento in vitro, sendo que várias foram as espécies que produziram altos níveis de CSVs. Observou-se in vitro que houve produção de mau cheiro característico de dentadura na presença de Klebsiela e Enterobacter e saliva. Foi observado ainda que isolados de enterobactérias foram capazes de aderir ao polímero da dentadura e se agregar na presença de sulfato de amônia. Contudo, não foi encontrada associação entre a presença de espécies de enterobactérias e os níveis de mau hálito, avaliado através do Halimeter ${ }^{\mathrm{TM}}$.

WALER ${ }^{126}$, em 1997, estudou 6 homens e 6 mulheres, todos estudantes de odontologia, com boa condição de higiene oral e boa condição periodontal. Possuíam boa saúde geral e periodontal, e não faziam uso de medicamentos. Os indivíduos eram instruídos a escovar os dentes na noite anterior ao teste, mas na manhã do teste não o faziam, e não podiam comer, beber ou fumar. As avaliações do hálito foram feitas através do Halimeter ${ }^{\mathrm{TM}}$, tomando-se três medidas para cada indivíduo e realizada a média. Após a obtenção das medidas iniciais, os indivíduos bochecharam por 30 segs $5 \mathrm{ml}$ de soluções com enxofre e medidas subseqüentes foram feitas. Os 
bochechos consistiam de solução aquosa de L-cisteína, L-metionina, glutathione oxidada e reduzida, e cistina* . Todas as soluções foram preparadas em 6 mM, pH 7.2, e todos os indivíduos usaram todas as soluções de teste, em dias separados. Os experimentos demonstraram que a cisteína foi rapidamente metabolizada em CSVs na cavidade bucal, e também que os valores mais altos foram obtidos com a cisteína. Observou-se, também, que a região de maior produção de CSVs foi o dorso da língua.

WILLIS et al. ${ }^{128}$, em 1999, observaram a relação entre intensidade do mauhálito, crescimento de bactérias redutoras de sulfetos e taxas de redução de sulfetos na boca humana. Avaliaram 30 voluntários adultos saudáveis com mauthálito. Os voluntários se abstiveram de higiene bucal por 24 horas antes da coleta das amostras, e não beberam ou comeram na manhã da coleta. A severidade do mauthálito foi determinada pela utilização do Halimeter ${ }^{\mathrm{TM}}$ e método organoléptico. Foi coletada saliva estimulada de cada indivíduo, assim como amostras de placa bacteriana das porções anterior e posterior da língua, mucosa do vestíbulo, mucosa alveolar vestibular, placa sub e supragengival, para determinação da contagem de microorganismos viáveis, número de bactérias redutoras de sulfeto e atividade sulfeto-redutora. A incidência de bactérias redutoras de sulfeto foi de $97 \%$ nos 30 voluntários, com base na contagem viável, e foram encontradas em todos os sete sítios examinados, sendo que o maior número médio encontrado destas bactérias foi na saliva e o menor número foi na mucosa alveolar vestibular. Em cada indivíduo e em cada sítio testado foi encontrada correlação altamente positiva $(p=0,0004)$ entre atividade sulfeto-redutora e proporção de bactérias redutoras de sulfeto. Encontrouse fraca relação entre os valores organoléptico e do Halimeter ${ }^{\mathrm{TM}}$ para o mauthálito, sem relação significante observada entre contagem viável total e intensidade do hálito. Tanto os números populacionais de bactérias redutoras de sulfeto como a atividade sulfeto-redutora foram negativamente relacionados com o mau-hálito pelo método organoléptico. Também foi negativa a relação entre crescimento e atividade de bactérias sulfeto-redutoras e valores halimétricos para cada indivíduo, porém, sem significância estatística. Concluiu-se que a fraca relação entre o método

\footnotetext{
* Sigma Chemical Co, St. Louis, MO, USA.
} 
organoléptico e halimétrico indicou que sulfetos voláteis não foram os principais determinantes de mauthálito na população estudada.

Com o objetivo de examinar a associação entre o hálito bucal total e níveis de sulfetos e fatores demográficos, e também de observar o mauthálito bucal total e níveis de sulfetos e parâmetros clínicos em todo a boca, MORITA; WANG73 examinaram 81 pacientes, que foram avaliados quanto ao mau-hálito pelo método organoléptico e por um monitor de sulfetos (Halimetro ${ }^{\mathrm{TM}}$ ). A saburra foi avaliada visualmente e classificada em graus de 0 a 3 (não visível até mais de dois terços da língua). Também foram avaliados os tecidos moles, cáries, profundidade de sondagem e sangramento à mesma. Um monitor de sulfetos sulculares foi utilizado e feito o escore do teste BANA ${ }^{\mathrm{TM}}$. Foi observado que o volume de saburra e o índice de sangramento foram os fatores mais fortemente relacionados tanto ao valor organoléptico quanto ao valor da halimetria. $\mathrm{O}$ gênero feminino e hábito de fumar foram negativamente associados com os valores organolépticos, e o escore do teste $\mathrm{BANA}^{\mathrm{TM}}$ da saburra foi significantemente relacionado com os valores da halimetria.

\subsection{Teste BANA ${ }^{\mathrm{TM}}$ e saburra}

$\mathrm{O}$ teste $\mathrm{BANA}^{\mathrm{TM}}$ constitui um método enzimático, empregado como indicador da presença de microorganismos responsáveis por doenças periodontais. Enzimas comuns a bactérias periodontopatogênicas podem ser identificadas a partir deste teste ${ }^{38}$.

Treponema denticola, Porphyromonas gingivalis e Bacteróides forsyhtus são espécies de organismos gram-negativos assacarolíticos (que não utilizam a quebra da sacarose para obtenção de energia) anaeróbicos, que aparentemente são únicas entre as bactérias que residem na superfície dental, pelo fato de produzirem uma enzima (arginina hidrolase) que hidrolisa o peptídeo sintético benzoil-DL-arginia-naftilamida (BANA), sendo este o mais acurado substrato dentre os substratos de naftilamida sintética para refletir a doença clínica em pacientes não tratados de periodontite ${ }^{106} \mathrm{e}$ gengivite ${ }^{39}$. Pode ser utilizado com segurança na clínica, uma vez que a acurácia do 
teste na detecção de Treponema denticola, Porphyromonas gingivalis e Bacteróides forsyhtus já se revelou comparável à sonda de DNA e ELISA66, 67.

O teste consiste de um cartão onde em uma parte um papel filtro é impregnado com BANA, e papel de nitrocelulose é impregnado com o corante "fast black K”. A tira de papel com BANA, na porção inferior do cartão, onde é colocado o material coletado para análise (placa dental, saburra, por exemplo), pode ser dobrada superiormente para que entre em contato com o corante, onde é colocada uma gota de água destilada. Este contato é mantido e a fita pode ser posicionada em um incubador específico ou à temperatura ambiente, por 30 minutos. Havendo bactérias que hidrolizam o BANA no substrato analisado, desenvolve-se uma cor no cartão, que pode ser azul claro ou escuro, lendo-se, desta forma: negativo - ausência de cor azul; fracamente positivo - cor azul pálido; positivo - discreto azul escuro. A cor desenvolvida é permanente e pode ser utilizada como forma de arquivo. ${ }^{66}$.

De acordo com BRETZ; LOESCHE, o teste BANA $^{\mathrm{TM}}$ é simples de ser realizado, de baixo custo, e útil para o monitoramento dos níveis bacterianos específicos ${ }^{19}$.

O dorso da língua apresenta cobertura de milhões de microorganismos. $\mathrm{Na}$ putrefação dos restos alimentares e células descamadas que ficam na língua, sulfeto de hidrogênio e metil mercaptana são produzidos, e ambos possuem relação direta com o mau hálito ${ }^{114}$, mas apesar de a limpeza da língua ser recomendável, muitas pessoas não gostam de colocar objetos para dentro da garganta, pois podem causar reflexo de vômito ${ }^{25}$. Além disso, a simples limpeza da língua pode não ser eficiente na eliminação do mau-hálito, pois isto não elimina o motivo pelo qual a saburra se forma ${ }^{110}$. 
Dispositivos antigos, os quais se acredita que sejam implementos para remover detritos da língua, foram encontrados. Eles provém da África, América do Sul, Índia e Arábia 24.

GILMORE; BHASKAR ${ }^{45}$, em 1972, já haviam relatado que a escovação da língua não apenas melhora a aparência clínica deste órgão, mas também reduz a população bacteriana relacionada.

YAEGAKI; SANADA ${ }^{129}$, em 1992, realizaram estudo em que relacionaram o peso da saburra e a análise dos CSVs. Trinta e um indivíduos participaram do estudo, divididos em indivíduos com e sem doença periodontal, e a análise do CSVs foi feita através de cromatografia gasosa. A saburra de cada indivíduo foi removida, e seu peso úmido avaliado (mg), e novas análises de CSVs foram realizadas. O grupo com doença periodontal possuía muito mais saburra do que o grupo controle, e a produção de CSVs pela saburra do grupo com doença periodontal foi 4 vezes maior do que nos grupos controle, e, após a remoção da saburra, a produção de CSVs em ambos os grupos caiu praticamente pela metade.

GOLDBERG et al. ${ }^{46}$, em 1994, examinaram a possibilidade de que a cadaverina e putrescina estivessem associadas com o mauthálito. Examinaram 52 indivíduos não-fumantes, sem doença sistêmica, que não estivessem utilizando medicamentos, e que não usavam próteses totais. Foi realizada avaliação da concentração de CSVs através de monitor portátil de sulfetos $\left(\right.$ Halímetro $^{\mathrm{TM}}$ ), avaliação com juízes de odor e análise do teste $\mathrm{BANA}^{\mathrm{TM}}$ com material proveniente de bolsa periodontal, dorso da língua e saliva. Os autores afirmaram haver evidência da participação de cadaverina como componente do mau-hálito. Houve relação entre o nível de cadaverina e medida de CSVs, mas não entre o nível de cadaverina e o teste BANA $^{\mathrm{TM}}$.

Em um estudo em 1995, DE BOEVER; LOESCHE 31 assumiram a hipótese de que se a flora anaeróbica na superfície da língua é a principal fonte de CSVs na boca, então o mau hálito deveria diminuir com mudanças na composição bacteriana 
da saburra. Para testar esta hipótese, 14 indivíduos com queixas subjetivas de halitose foram tratados com antimicrobianos depois da tomada dos valores basais dos CSVs, através do aparelho Halimeter ${ }^{\mathrm{TM}}$. Três leituras separadas foram tomadas para cada indivíduo, e o valor médio foi usado na análise estatística. Medidas do odor foram estabelecidas através de avaliação pelos examinadores. Os participantes ficavam com a boca fechada por 1 minuto e então sopravam suavemente a $10 \mathrm{~cm}$ do nariz do examinador, e a intensidade do hálito era anotada em uma escala de 0 a 4 . $\mathrm{O}$ mesmo foi feito com o paciente exalando pelo nariz. A quantidade de saburra foi avaliada visualmente. Foram tomadas as medidas de sondagem periodontal de todos os dentes, seis sítios por dente. O teste $\mathrm{BANA}^{\mathrm{TM}}$ foi usado com material removido da superfície mesial dos primeiros molares, 2 sítios dentais arbitrários e da saburra. Os pacientes bochecharam gluconato de clorexidina $0.12 \%$ por 7 dias. Duas vezes ao dia os participantes escovavam os dentes com o dentifrício de sua preferência, escovavam suas línguas com escova umedecida em clorexidina e bochechavam a clorexidina por 60 segundos. No fim deste período todos os parâmetros eram reavaliados. Foi observada correlação estatística entre os valores de CSVs e odor bucal e da língua, sendo que o odor da boca estava relacionado com o odor da língua e a quantidade de saburra. O estudo sugeriu ainda uma relação inversa entre a profundidade de sondagem e odor da boca, havendo diminuição do odor conforme aumentava a profundidade de sondagem. Houve relação entre o odor bucal e os valores do teste BANA ${ }^{\mathrm{TM}}$. Houve forte correlação entre a flora anaeróbica cultivável e odor da língua e boca, aumentando o odor conforme aumentava a quantidade de microorganismos assacarolíticos. O tratamento realizado diminuiu significantemente os níveis médios de CSVs. Todos os pacientes possuíam odor reconhecível antes do tratamento e ficaram sem odor após o período de tratamento, e as mudanças bacteriológicas acompanharam as mudanças observadas quanto ao odor, diminuindo também os valores do teste $\mathrm{BANA}^{\mathrm{TM}}$. Após o tratamento, houve diminuição da prevalência ou contagem total de P. intermedia, P. gingivalis e Fusobacterium, e houve aumento na proporção das espécies que produzem pouco ou nenhum odor, como Streptococcus, Lactobacillus, Rothia, Capnocytophaga e Actinomyces. 
SEEMANN et al. ${ }^{91}$, em 2001, compararam a efetividade de um limpador lingual, um raspador lingual e uma escova de dentes na capacidade de redução dos níveis de CSVs. Foram incluídos no estudo 28 indivíduos, divididos em três grupos, avaliados em três consultas distintas, utilizando em cada uma delas um diferente dispositivo de limpeza, sendo que cada indivíduo serviu como seu próprio controle. Pôde-se constatar ao final do estudo que o limpador lingual mostrou uma maior percentagem de redução dos CSVs do que a escova dental até 25 minutos após a limpeza da língua, e maior redução do que observada com o uso de raspador lingual até 15 minutos após a limpeza. Não foi constatada redução nos níveis de CSVs por períodos maiores do que 30 minutos após a limpeza, em nenhum dos indivíduos, o que levou os autores a questionarem o efeito clínico da limpeza da língua de forma isolada objetivando a redução do mau-hálito.

\subsection{Saliva e Fluxo Salivar}

A saliva é um componente vital para a manutenção da saúde e função bucais, sendo o principal protetor dos tecidos bucais, duros e moles 99 . Produzida em sua maior parte pelas glândulas salivares maiores (apenas $7 \%$ da saliva é produzida pelas glândulas salivares menores) ${ }^{99}$, ela tem função antimicrobiana, mantém a integridade e lubrifica a mucosa bucal, participa da limpeza e da digestão ${ }^{37}$. A saliva também oferece substratos que são oxidados nos processos de geração de odor, e sua acidez ou alcalinidade pode inibir ou favorecer, respectivamente, o desenvolvimento do mau odor ${ }^{121}$. Além disso, a saliva possui funções antimicrobianas, o que se deve à presença de constituintes de defesa orgânica na mesma, como lizosimas, leucotaxinas, opsoninas, lactoperoxidase, lactoferrina e imunoglobulinas, entre outros 109 .

Xerostomia é uma queixa subjetiva, que pode não estar relacionada aos achados físicos de boca seca e hipossalivação. Sua prevalência aumenta com a idade, devido à terapia com drogas, doenças sistêmicas, radioterapia, e pode estar relacionada à depressão, disfagia, problemas digestivos e desordens de fala ${ }^{4}$. A taxa de fluxo salivar pode ainda variar com o clima, idade, gênero, saúde geral e status da 
dentição ${ }^{18}$. Contudo, alguns medicamentos, como a pilocarpina, têm sido estudados para o alívio da xerostomia $49,64,75,111,123$.

Aproximadamente $0,3 \mathrm{ml}$ de saliva são produzidos por minuto em descanso e de 2 a $3 \mathrm{ml}$ durante estimulação. Uma taxa de saliva de menos de 0,1 a $0,2 \mathrm{ml}$ por minuto é anormal, assim como uma taxa estimulada menor do que 0,5 a $0,7 \mathrm{ml}$ por minuto $99,100$.

Uma forma simples de coletar a saliva envolve a expectoração da mesma em um tubo de boca larga marcados em mililitros. A coleta pode ser feita por um período de 5 minutos em condições de repouso, sem estímulo ou mastigação, pedindo-se ao paciente para não mover a língua ou lábios. A saliva estimulada pode ser depois coletada usando cera ou goma de mascar, ou ácido cítrico a 10\%, com coleta por mais 5 minutos 37 .

KLEINBERG; WESTBAY59 afirmaram que a saliva possui propriedades inibidoras, oriundas de um alto fluxo salivar, grande disponibilidade de oxigênio e menor oportunidade para degradação bacteriana de peptídeos e proteínas.

SOHN et al. ${ }^{97}$ estudaram a relação entre halitose e função das glândulas salivares. Analisaram 100 pacientes com queixa de halitose, através de exame salivar e obtiveram seus valores de CSVs medidos pelo Halimeter ${ }^{\mathrm{TM}}$. Os resultados mostraram 58 pacientes com salivação normal e 42 com salivação anormal. Os maiores valores de CSVs foram encontrados no grupo com salivação anormal ( $\mathrm{p}<0,01)$. Em 51 pacientes (36 com salivação normal e 15 com salivação anormal) obtiveram valores de CSVs abaixo de 100, e em 38 pacientes (21 com salivação normal e 17 com salivação anormal) obtiveram valores entre 100 e 200, e 11 pacientes ( 1 com salivação normal e 10 com salivação anormal) tiveram valores de CSVs acima de 200. Os resultados, de acordo com os autores, mostraram relação entre halitose e função de glândula salivar. 
TORRES; VIANNA ${ }^{118}$, entretanto, não encontraram diferenças nos níveis de conhecimento sobre halitose entre grupos com idades diferentes. Os autores compararam a avaliação da halitose entre dois grupos com idades diferentes. $\mathrm{O}$ grupo 1 (G1) foi composto de pacientes com idades variando de 19 a 54 anos, e o grupo 2 (G2) foi composto de pacientes com idade igual ou superior a 55 anos. Foram aplicados 80 que stionários com questões relativas à idade, o que entendem sobre halitose e sua origem, se a possuem, se a sentem quando acordam, se algum profissional da saúde foi procurado para resolver o problema, hábitos alimentares, rotina de higiene bucal, como escovação e uso do fio dental, uso de enxaguatório e limpeza da língua, sensação de boca seca, problemas de saúde, fumo, uso de medicamentos e próteses. Não houve diferença significante entre os grupos, embora houvesse maior conhecimento sobre higiene bucal em G1 e G2 mostrasse menor incidência do hábito de fumar. Os autores concluíram que não houve diferença entre os grupos e que há um relativo conhecimento sobre o assunto, e que o tratamento deve ser responsabilidade do cirurgião-dentista.

BRETZ et al. 17 e colaboradores, em 2000, realizaram um estudo para determinar o fluxo salivar de glândulas salivares menores (MSGO) de idosos com diferentes condições médicas e determinar a relação do MSGO com fatores demográficos, médicos, dentais, ingestão de medicamentos e reclamações subjetivas de boca seca. Dados foram obtidos de 653 indivíduos de várias clínicas, todos eles com mais de 60 anos. Os dados mostraram que indivíduos com alto MSGO tendem a usar mais medicamentos que os com baixo MSGO, sem diferença com relação à ingestão de medicamentos xerogênicos. Pessoas com baixo MSGO eram significantes mais velhas, e na maioria mulheres. Condição dental não mostrou relação com MSGO. No contexto geral, apresentar idade mais avançada, gênero feminino, o vício do fumo e queixa de boca seca foram associados a um baixo MSGO. 


\subsection{Auto-percepção do hálito}

Parece que as pessoas são incapazes de dizer se possuem mau-hálito ${ }^{36}$. Então, pessoas que possuem hálito podem desconhecer o fato, enquanto que indivíduos sem hálito perceptível podem imaginar que o possuem.

ROSENBERG et al. ${ }^{87}$, em 1995, determinaram se a auto-avaliação de odor, através de vários métodos, era capaz de oferecer uma maior compreensão da extensão do próprio mauthálito. Cinquienta e dois indivíduos participaram do estudo, e registraram seu nível de mauthálito em uma escala análoga visual (VAS) contínua de $10 \mathrm{~cm}$, tendo como extremidades "ausência de odor" e "odor extremamente fétido", de acordo com 5 metodologias: 1) avaliação pré-concebida; 2) odor sentido após exalar o ar pela boca com as mãos cobrindo boca e nariz; 3) odor no pulso 5 segundos após lamber o pulso perpendicularmente; 4) cheiro da saliva após 5 minutos fechada em placa de Petri a 37C; 5) avaliação final, após todos os outros métodos. Observourse que os indivíduos estudados foram incapazes, na maioria das vezes, de pontuar seus próprios níveis de mau-hálito, quando comparados a métodos objetivos (concentração de CSVs, obtida com monitor portátil de sulfetos; nível de cadaverina; índice de placa; índice gengival; profundidade de sondagem; teste $\mathrm{BANA}^{\mathrm{TM}}$ ), ao passo que houve relação entre estes parâmetros e a avaliação feita por juízes de odor.

AYESH, MITCHELL \& SMITH ${ }^{6}$, em 1995, afirmaram que problemas de mau cheiro corporal, reais ou não, podem ser clinicamente importantes, e que tal fenômeno não é bem compreendido, e pode gerar angústia no indivíduo afetado.

HAM et al. ${ }^{48}$ revelaram, em 1999, a relação entre halitose e o perfil psicológico. Foram avaliados através de Cheklist - 90 - revision (SCL-9-R) 135 pacientes com halitose, 118 pacientes com desordem temporomandibular (grupo denominado pelo autor como controle 1) e 90 pessoas normais (grupo controle 2). Em todos os grupos foram encontrados valores normais na escala SCL-90-R. Comparado com o grupo normal, o grupo controle 1 teve valores maiores na escala 
de somatização, obsessão-compulsão, depressão, ansiedade e hostilidade. Comparado ao grupo normal, o grupo com halitose teve maiores valores para somatização, obsessão-compulsão, sensibilidade interpessoal e psicose. Segundo os autores, os valores sugerem que tendências psicopatológicas podem estar associadas com halitose e podem ser estimadas pelo questionário SCL-90.

A sensação errônea de possuir mau hálito está associado a alterações psicológicas. DIOS et al. ${ }^{33}$, em 2000, relataram a relação entre esquizofrenia e halitose, onde o gradiente alveolar de alguns compostos orgânicos voláteis, como pentano e carbono dissulfeto, são maiores em pacientes com esquizofrenia. Além disso, pacientes com "síndrome de referência olfatória", quando reclamam que podem notar cheiro ruim que outras pessoas não podem, têm como uma de suas principais variantes "Halitose Ilusória".

\subsection{A fissura lábio-palatina}

Fissura de lábio e palato é uma deformidade que afeta todo o complexo facial médio se não for corrigida ou for tratada incorretamente ${ }^{2}$. É um defeito estrutural que geralmente afeta outras áreas func ionais - fala, audição, mastigação - dependendo da extensão da fissura. Complicações podem surgir com respeito à alimentação, aparência facial, fala, audição, função dental e desenvolvimento psicossocial ${ }^{10}$.

As fissuras de lábio e palato são deformidades congênitas classificadas entre o grupo das displasias, caracterizadas por erros de fusão dos processos faciais embrionários. Em seu mecanismo de formação observa-se uma alteração da velocidade migratória das células da crista neural encarregadas de comandar o fenômeno da fusão dos processos faciais, entre a sexta e a oitava semana de vida embrionária. Ocorre um atraso da migração das células do neuroectoderma em uma área específica de fusão. Quando tais células alcançarem o ponto determinado para fusão, não mais encontrarão uma membrana ectodérmica favorável à lise necessária à fusão, estabelecendo-se assim a fissura ${ }^{94}$. A falta de coalescência dos processos nasais mediais resultará em fissura mediana, cuja extensão varia de acordo com a 
época de atuação do agente teratogênico. A não coalescência dos processos nasais mediais com os processos maxilares resulta na fissura labial. A ausência de fusão dos processos palatinos resulta nas fissuras palatinas 22 .

Acredita-se que as fissuras de lábio e palato possuem etiologia multifatorial, isto é, fatores genéticos e não genéticos, e aparecem em decorrência de desvios ou falhas na sequiência de formação daquelas estruturas durante o desenvolvimento embrionário $^{22}$. O fator hereditário pode ser identificado em $35 \%$ dos portadores da deformidade, e os fatores ambientais respondem pelos $65 \%$ restantes e, dentre estes, podem ser citados aspectos maternos, estresse, infecções, fatores alimentares, medicamentos, irradiações, tabagismo e alcoolismo. $22,94$.

Grande parte dos pacientes portadores de fissura labiopalatina realizam a faringoplastia para eliminar a hipernasalidade em pacientes com fala hipernasal. Tal procedimento sugere acarretar complicações aéreas que podem ser temporárias (período pós-operatório), de curta duração ou longa duração. Geralmente as complicações aéreas estão relacionadas a algum tipo de obstrução, parcial ou completa 94 .

No mundo desenvolvido, a prevalência de fissuras de lábio e/ou palato é de 1:700 nascimentos, sendo $20 \%$ de lábio, $20 \%$ de palato e $60 \%$ de lábio e palato ${ }^{54}$.

Um levantamento realizado em escolares na cidade de Bauru - SP mostrou que a prevalência foi de 1:650 nascimentos, sendo que as lesões de maior gravidade foram mais freqüentes no gênero feminino ${ }^{21}$.

Pacientes fissurados podem ter passagem nasal reduzida como resultado de obstrução osteal, desvio de septo, hipertrofia de concha inferior, colapso valvar e fluxo de ar reduzido 2,127 . Tais condições patológicas que afetam o nariz, faringe ou árvore traqueobrônquica podem resultar na produção de odores desagradáveis, pois levam à proliferação de bactérias gram- negativas 12 . 
Basicamente são três os tipos de fissuras, que podem envolver o palato primário (anterior ao forame incisivo) e palato secundário (posterior ao forame incisivo) 95 :

1. Fissura no palato primário - lábio e alvéolo. Pode ser unilateral, mediano ou bilateral;

2. Fissura no palato secundário - palato duro e mole;

3. Fissura no palato primário e secundário.

As fissuras Pré-Forame são aquelas que atingem o lábio, uni ou bilateralmente, e vão desde o vermelhão deste, podendo chegar até o forame incisivo. Elas podem comprometer apenas o vermelhão do lábio, portanto não comprometendo a parte cutânea do lábio, ou subir em direção ao assoalho do nariz, nos mais variados graus, até chegar ao forame incisivo, sendo então classificada como uma Fenda Completa. O comprometimento ósseo pode ocorrer, embora de forma mais leve, nas fissuras incompletas, mas é normalmente maior nas fissuras completas. O palato divide-se em Anterior ou Duro e Posterior ou Mole. As fissuras Pós-Forame são aquelas que atingem o palato, e vão desde a úvula, até o forame incisivo. Elas podem acometer apenas a úvula, que pode estar apenas sulcada, ou caminhar de trás para frente, nos mais variados graus, até atingir o forame incisivo, e aí se tornar uma fissura Pós-Forame Completa ${ }^{3}$. As fissuras Trans-Forame são aquelas que atingem tanto o palato primário como o secundário.

A figura 1 mostra os diferentes tipos de fissuras de lábio e/ou palato. 

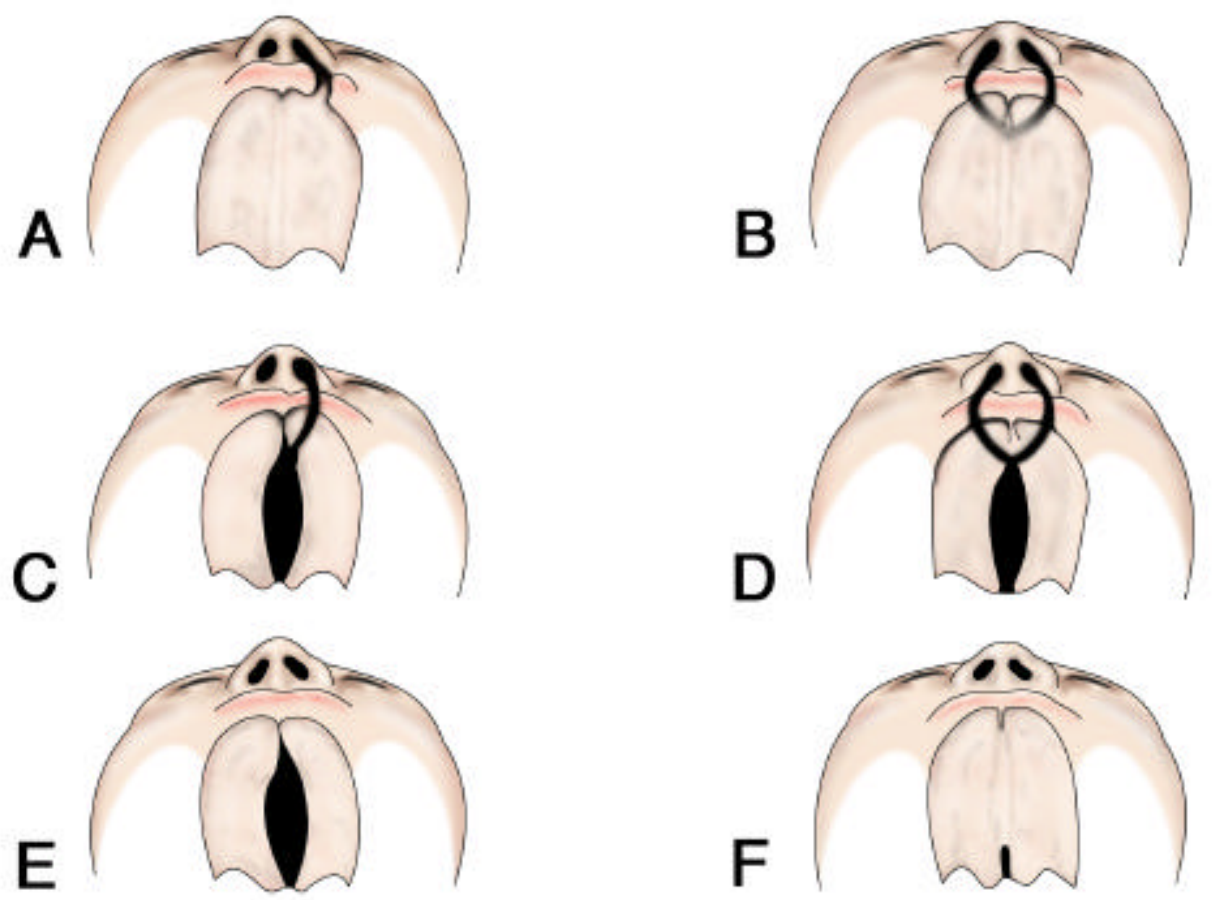

FIGURA 1 - Diferentes tipos de fissuras de lábio e/ou palato: A) fissura de palato primário - fissura unilateral pré-forame incisivo incompleta; B) fissura de palato primário - fissura bilateral pré-forame incisivo completa; C) fissura de palato primário e secundário - fissura unilateral transforame incisivo; D) fissura de palato primário e secundário - fissura bilateral transforame incisivo; E) fissura de palato secundário - fissura pósforame incisivo completa; F) fissura de palato secundário - úvula bífida

De acordo com a modificação proposta por SILVA FILHO et al ${ }^{95}$ da classificação das fissuras labiopalatinas anteriormente proposta por Spina et al., pode-se classificá-las de acordo com a tabela 1 . 
TABELA 1 - Modificação da classificação das fissuras labiopalatinas 95

\begin{tabular}{|c|c|c|c|}
\hline \multirow[t]{2}{*}{ GRUPO I } & \multirow[b]{2}{*}{ - unilateral } & \multirow[t]{2}{*}{ direita } & completa \\
\hline & & & \begin{tabular}{|l} 
incompleta \\
\end{tabular} \\
\hline \multirow[t]{2}{*}{ Pré-forame incisivo } & & \multirow[t]{2}{*}{ esquerda } & completa \\
\hline & & & incompleta \\
\hline \multirow{3}{*}{$\begin{array}{l}\text { GRUPO II } \\
\text { Trans-forame incisivo }\end{array}$} & \multirow[t]{2}{*}{ - unilateral } & \multicolumn{2}{|l|}{ direita } \\
\hline & & \multicolumn{2}{|l|}{\begin{tabular}{|l|} 
esque rda \\
\end{tabular}} \\
\hline & \multicolumn{3}{|l|}{$\begin{array}{l}\text { - bilateral } \\
\text { - mediana }\end{array}$} \\
\hline GRUPO III & \multirow{2}{*}{\multicolumn{3}{|c|}{$\begin{array}{ll}\text { - } & \text { completa } \\
\text { - } & \text { incompleta }\end{array}$}} \\
\hline Pós-forame incisivo & & & \\
\hline
\end{tabular}

\section{GRUPO IV}

Fissuras raras da face

Observando a escassez de informações sobre halitose em pacientes portadores de fissura de lábio e/ou palato, e para melhor compreensão da dinâmica da halitose, é que resolvemos realizar este estudo. Trata-se de uma pesquisa inédita nesta área, uma vez que não encontramos na literatura um único relato que demonstre tal preocupação. 


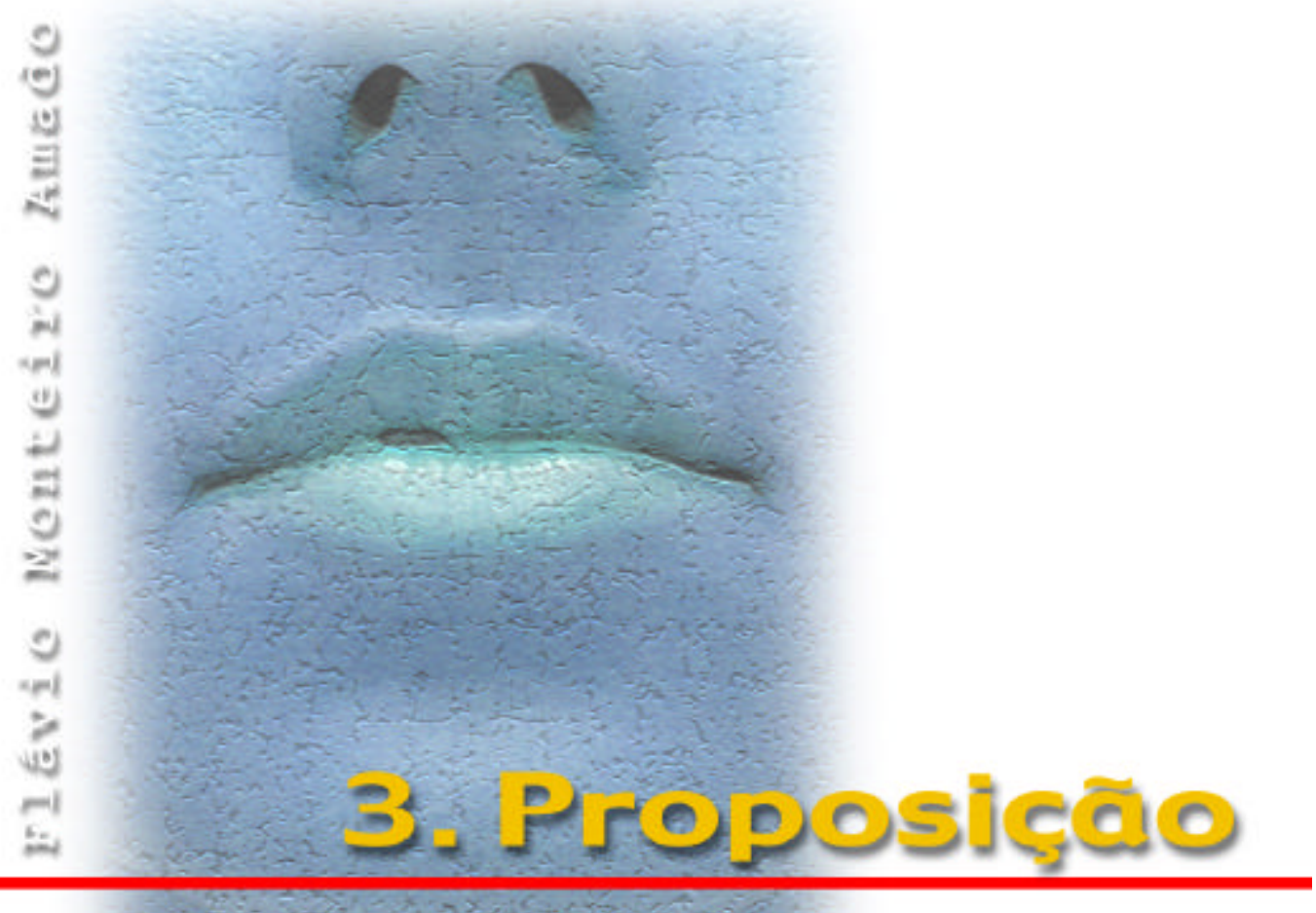




\section{3-PROPOSIÇÃO}

O propósito deste trabalho consistiu-se em:

- Avaliar o hálito bucal e nasal em pacientes sem fissura de lábio e/ou

palato (grupo 1), e com fissura (grupo 2), comparando os resultados entre os grupos;

- Investigar as relações entre os parâmetros estudados (peso seco da saburra lingual, fluxo salivar com e sem estimulo, teste BANA) e a halitose bucal;

- Verificar se há relação entre a percepção do individuo de seu hálito e os valores de halimetria bucal. 


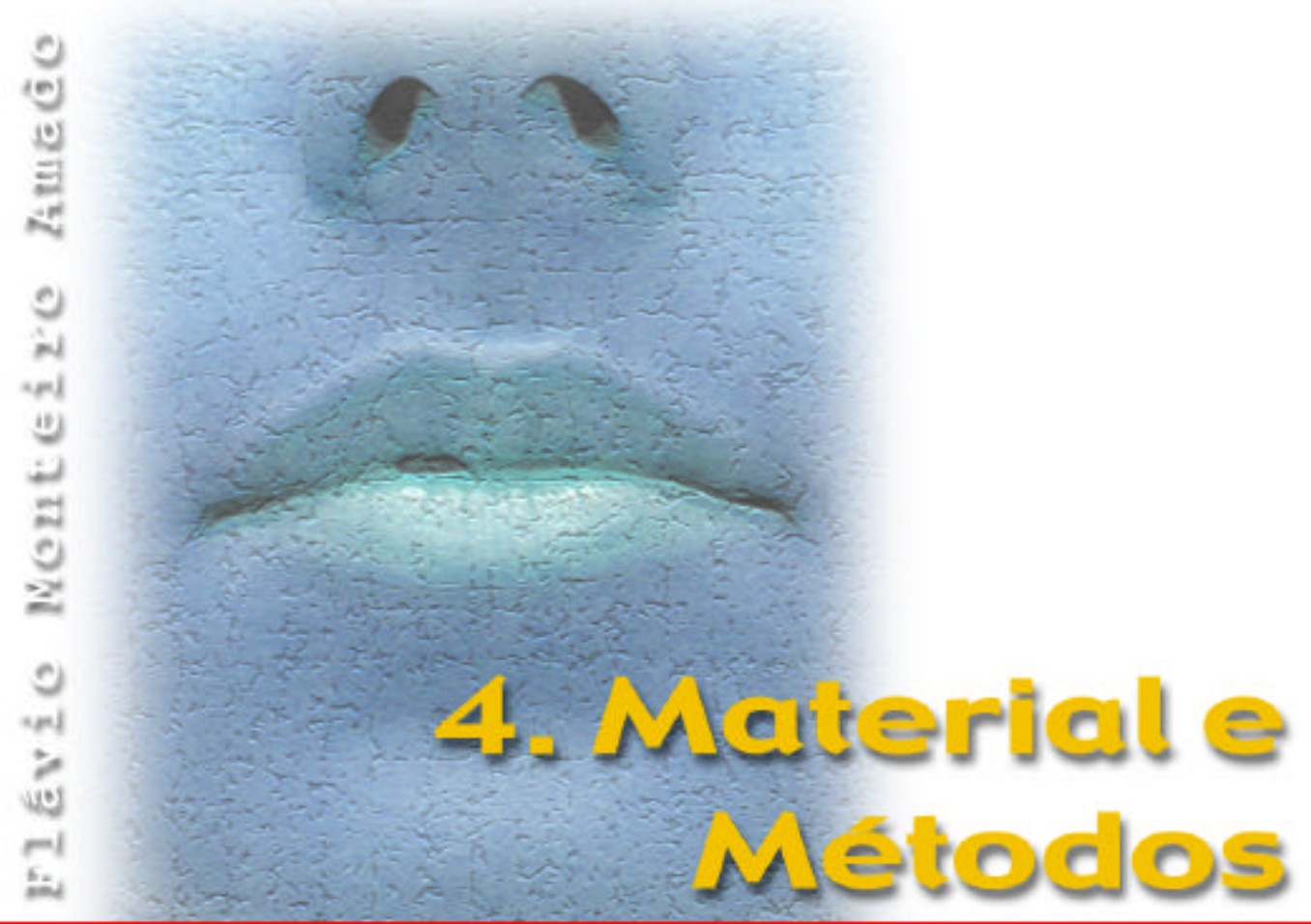




\section{MATERIAL E MÉTODOS}

O projeto de pesquisa foi enviado ao Comitê de Ética em Pesquisa da Faculdade de Odontologia de Bauru, da Universidade de São Paulo, e aprovado.

\subsection{Seleção da amostra}

A amostra foi constituída de 42 indivíduos, divididos em dois grupos distintos:

- Grupo 1 - constituído de 21 indivíduos sem fissura, saudáveis, sem doenças sistêmicas importantes relatadas;

- Grupo 2 - constituído por 21 indivíduos com fissura lábio-palatal que já haviam realizado cirurgia reparadora, e sem alterações sistêmicas importantes relatadas.

As idades dos indivíduos variaram de 21 a 30 anos para o grupo 1, com media de 26,19 anos; o grupo 2 teve media de idade de 24,23 anos, variando de 19 a 33 anos.

Os pacientes do grupo 1 foram escolhidos entre alunos de Odontologia da Faculdade de Odontologia de Bauru - Universidade de São Paulo. Os pacientes que constituíram o grupo 2 foram selecionados entre pacientes do Hospital de Reabilitação de Anomalias Craniofaciais - HRAC-USP (Centrinho).

Todos os indivíduos responderam a um questionário (apêndices 4 e 5) relativo a dados pessoais e à saúde geral e bucal, hábitos de vida e alimentares, onde também foram anotados os dados relativos aos parâmetros de halitose, que foi preenchido pelo cirurgião-dentista encarregado do exame clínico do paciente. Após responderem ao questionário, os pacientes foram submetidos a um exame para avaliação de sua saúde bucal e observação de qualquer fator que pudesse interferir no hálito. 


\subsection{Protocolo experimental}

\subsubsection{Orientações prévias e início da consulta}

Previamente aos exames os pacientes receberam orientações (apêndice 3) para uma maior padronização em relação à coleta dos dados. As orientações foram:

1. Evitar, 24 horas antes da consulta, comida muito condimentada.

2. Evitar, 3 horas antes da consulta:
a. Escovar os dentes;
b. Usar fio dental;
c. Usar enxaguatório bucal;
d. Usar pastilhas ou chiclete;
e. Bebidas alcoólicas;
f. Fumar.

3. No momento da consulta não estar usando perfumes ou outras substâncias aromatizantes.

Com a mesa preparada para o atendimento do paciente (Figura 2), e o mesmo sentado na cadeira, cada paciente foi questionado quanto à auto-percepção do hálito, antes do início da coleta dos dados. Foram apresentadas a cada paciente duas escalas de zero a dez, para que fosse circulado o valor correspondente ao hálito no momento da consulta e em um dia qualquer, considerando "0" o melhor hálito possível, e "10" o pior, conforme abaixo:

\section{HOJE}

$\begin{array}{lllllllllll}\mathbf{0} & 1 & 2 & 3 & 4 & 5 & 6 & 7 & 8 & 9 & 10\end{array}$

\section{EM UM DIA COMUM}

$\begin{array}{lllllllllll}\mathbf{0} & 1 & 2 & 3 & 4 & 5 & 6 & 7 & 8 & 9 & 10\end{array}$

Após este procedimento deutse a coleta dos valores de halimetria. 


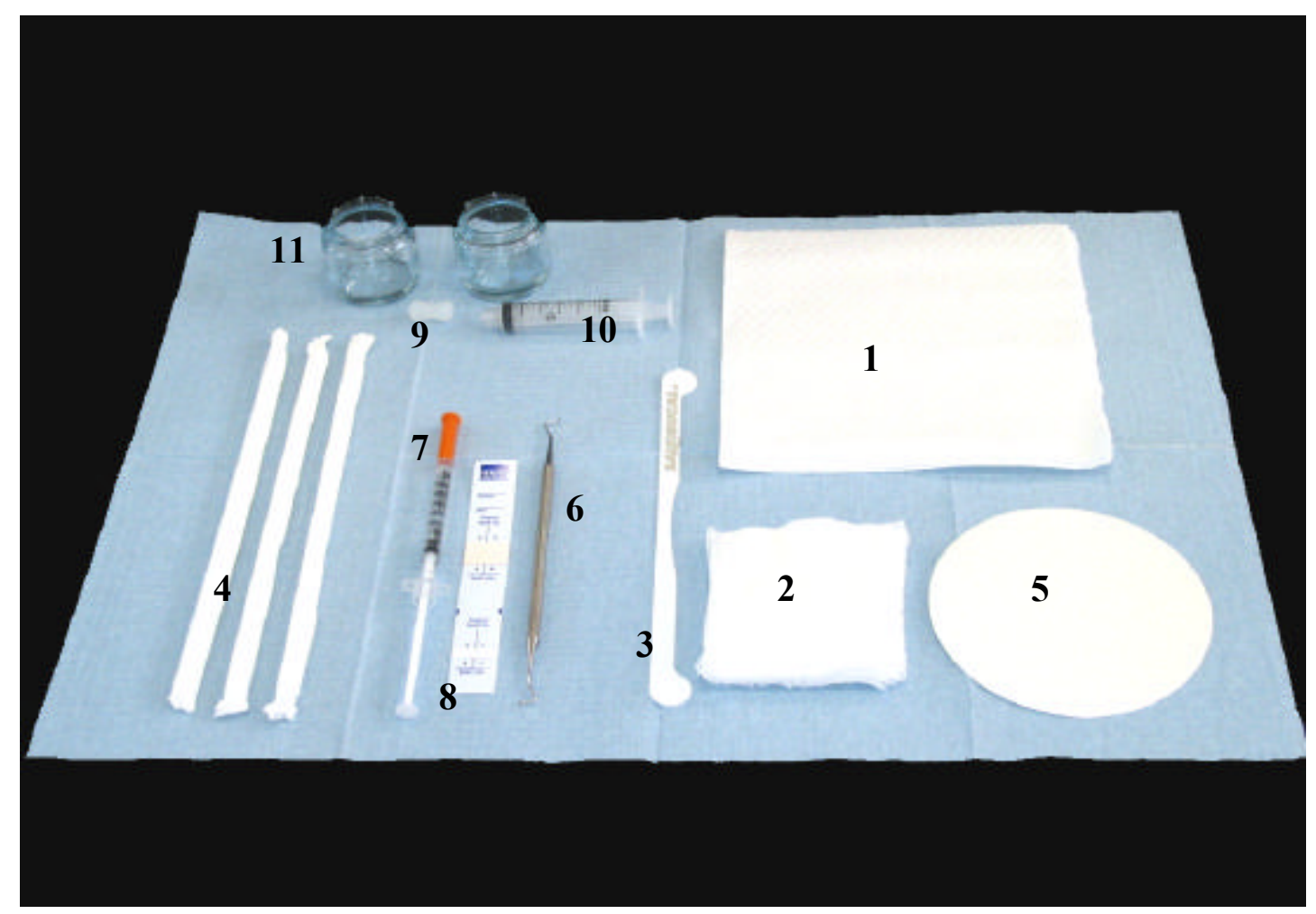

FIGURA 2 - Mesa de atendimento do paciente: 1) guardanapo; 2) gaze; 3) limpador de língua; 4) canudos; 5) papel filtro; 6) colher de dentina; 7) água destilada; 8) fita teste BANA; 9) hiperbolóide; 10) seringa para sialometria; 11) vidros para coleta de saliva

\subsubsection{Coleta dos valores de halimetria}

Com o intuito de quantificar os valores do hálito e diferenciar as fontes de odor, foram realizadas as halimetrias nasal e bucal de todos os indivíduos, com a utilização do aparelho Halimeter ${ }^{\mathrm{TM}}$ (Interscan corporation, Chatsworth, USA) (Figura 3). Cada paciente ficou sentado sem falar por 1 minuto, com a boca fechada. Um canudo plástico descartável conectado ao monitor de sulfetos foi introduzido 4 $\mathrm{cm}$ dentro da boca do paciente.O paciente foi instruído para trazer a boca levemente aberta sobre o canudo, e não inspirar ou expirar durante as leituras (Figura 4). 


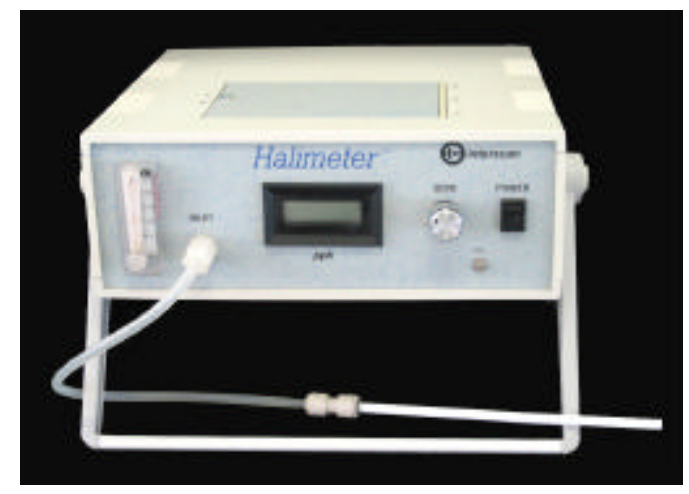

FIGURA 3 - Halimeter $^{\mathrm{TM}}$

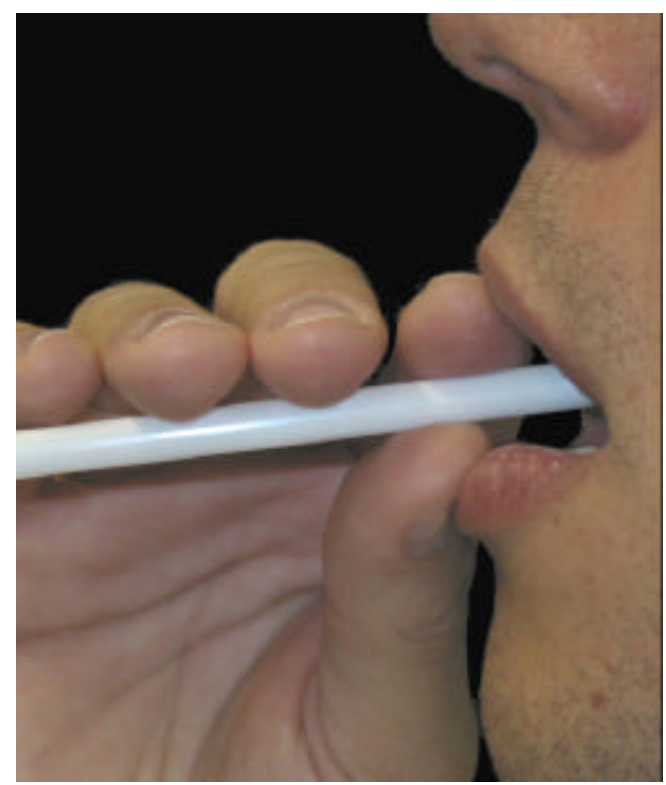
para leitura da concentração dos CSVs

O monitor de sulfetos possui uma bomba que puxa o ar pelo canudo, e assim que o ar passa pelo sensor eletrolítico, a concentração dos CSV é detectada. Quando o aparelho registrasse o valor máximo no monitor, em partes por bilhão, este dado era registrado (Figura 5).

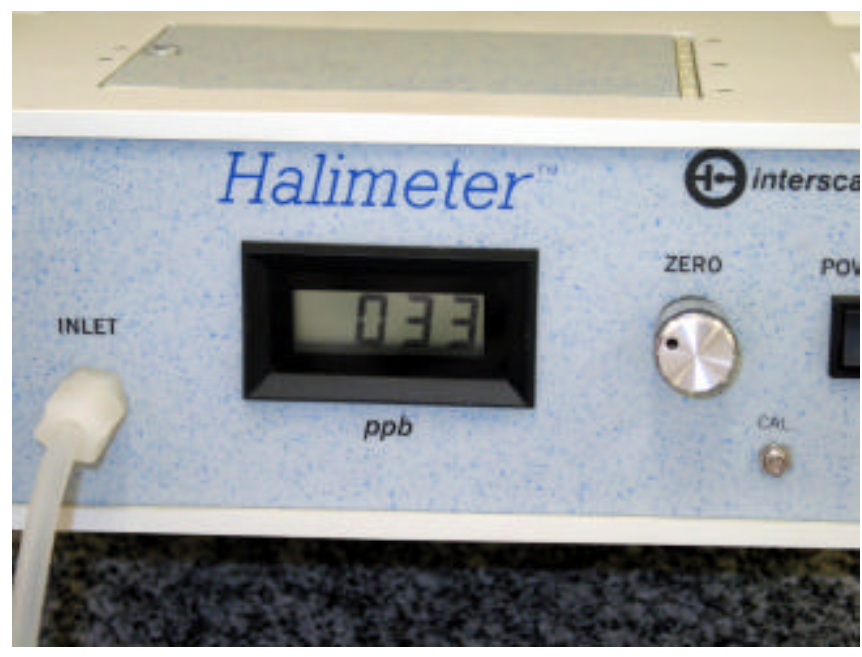

FIGURA 5 - Registro do valor máximo no monitor do aparelho

As medidas de CSVs bucais foram realizadas em triplicata, sendo obtida uma média, e entre cada medida do hálito o paciente permanecia de boca fechada durante 1 minuto. O procedimento foi realizado uma quarta vez, simultaneamente à expiração lenta do paciente, procurando identificar, desta forma, um aumento ou 
redução dos valores de halimetria conforme o ar bucal se misturava com o ar proveniente dos pulmões, demonstrando assim causa sistêmica de hálito. A medida foi realizada também uma vez em cada narina, introduzindo-se o canudo $1 \mathrm{~cm}$ dentro da narina, sendo que os pacientes também permaneceram sem inspirar ou expirar durante as leituras (Figura 6). As medidas de odor nasal foram únicas para cada narina.

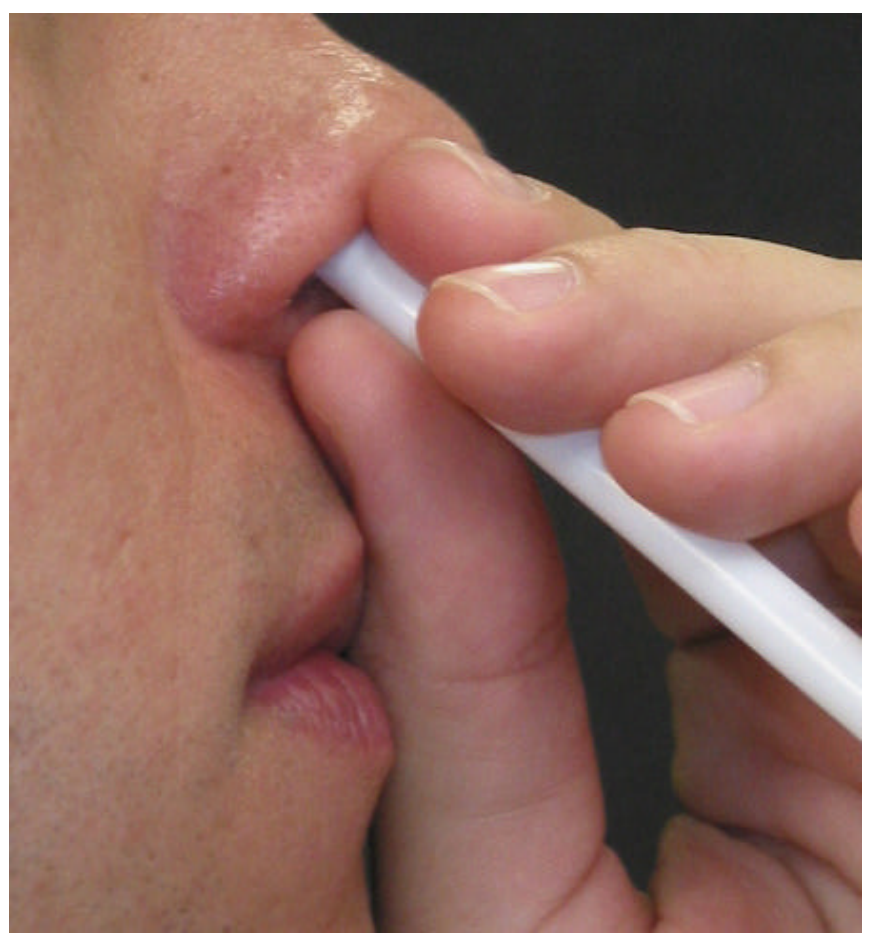

\section{FIGURA 6}

Medição do valor de halimetria nasal

\subsubsection{Avaliação da saburra e novas medidas de halimetria}

O excesso de umidade da língua foi removido com uma gaze (Figura 7a) e a saburra foi removida completamente com um limpador lingual ${ }^{*}$ da empresa SaudBucal $^{\circledR}$ (Figura 7b) e colocada em um papel filtro** (Figura 7c) previamente pesado. Uma pequena parte do material colhido foi utilizado para a realização do teste $\mathrm{BANA}^{\mathrm{TM}}$, e o restante foi armazenado durante 24 horas para secagem e

\footnotetext{
* SaudBucal, HCL Representações e Comércio, Ltda.

** Toyo Roshi Kaisha, Ltd.
} 
posterior pesagem, obtendo-se desta forma o peso da saburra, através de balança de precisão* (figura 7d).

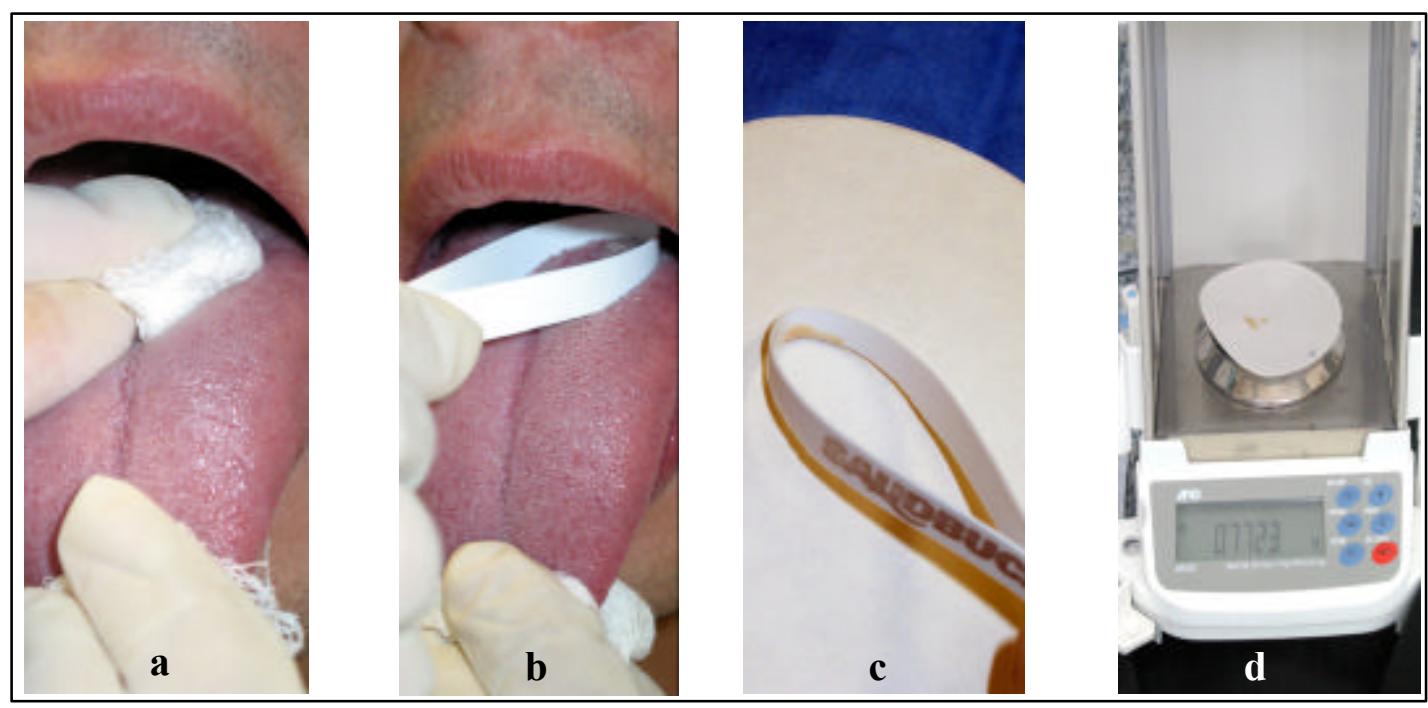

FIGURA 7 - a) remoção do excesso de umidade da língua; b) remoção da saburra; c) colocação da saburra sobre o papel filtro; d) pesagem da saburra em balança de precisão

Após a remoção da saburra as medidas de hálito bucal foram tomadas novamente, com a intenção de identificar a redução da concentração dos CSVs.

\subsubsection{Teste BANA ${ }^{\mathrm{TM}}$}

O teste BANA foi realizado com a intenção de pesquisar uma relação entre a presença de microorganismos BANA positivos e os valores elevados de halimetria. Uma pequena parte do material colhido com o raspador lingual foi transferido para a fita de teste BANA $^{\mathrm{TM}}$ com o auxílio de um escavador** (Figura 8a). Uma gota de água destilada foi derramada sobre o local do reagente (Figura 8b), e a fita dobrada, mantida desta forma com um clipe de papel, para que o reagente entrasse em contato com o material orgânico (Figuras 8c e 8d), permanecendo assim por 1 dia inteiro, conforme indicado pelo distribuidor, quando então foi observada a reação e obtido o

\footnotetext{
* A\&D Company, Limited, Tokyo, Japan.

** Escavador ICE 17, Indústria Brasileira.
} 
resultado, classificado em 0 (negativo), (1) fracamente positivo, (2) positivo, de acordo com a coloração obtida.

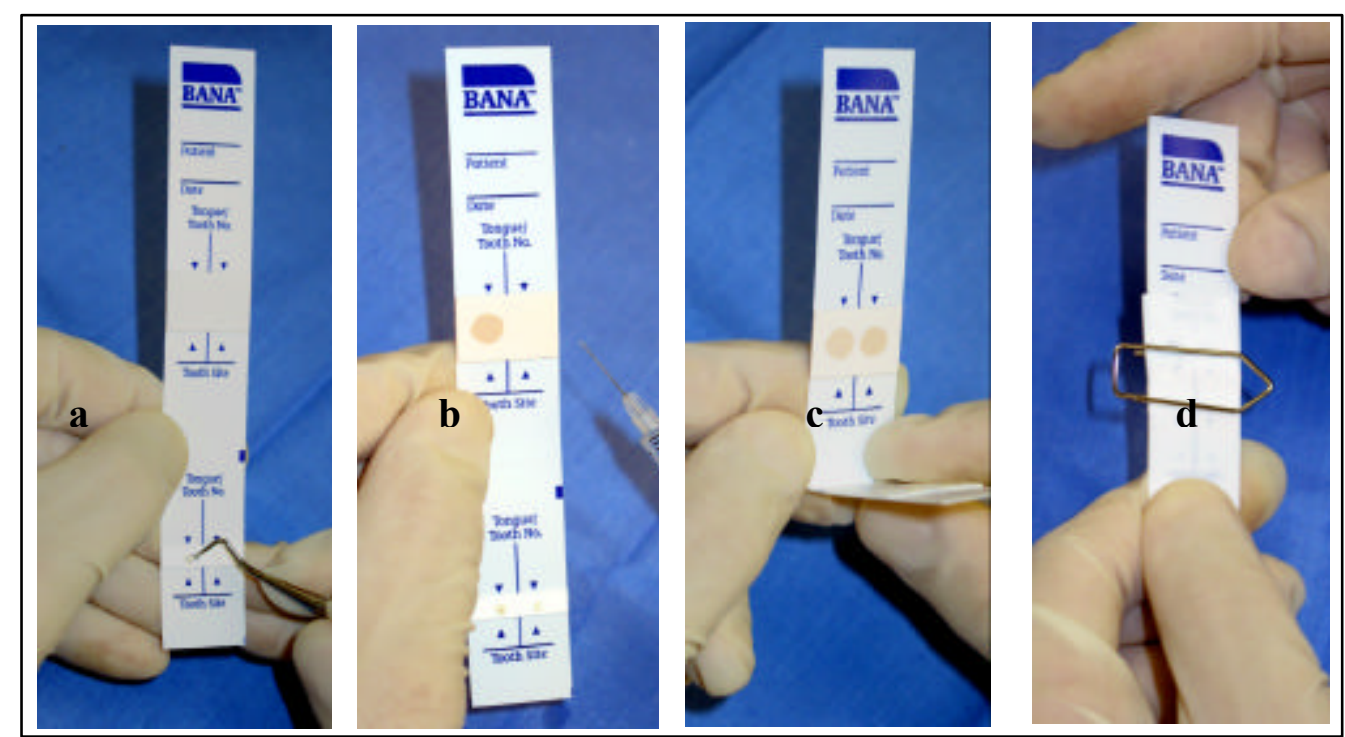

FIGURA 8 - a) colocação da saburra na fita teste com colher de dentina; b) colocação de água destilada na fita teste; c) dobragem da fita; d) fita presa com clipe de papel

\subsubsection{Sialometria}

Foi obtido o fluxo salivar, ou sialometria, em repouso da seguinte forma: inicialmente o paciente permaneceu por 5 minutos em repouso, de olhos abertos, sem estimular a salivação, e verteu toda a saliva obtida em um recipiente de vidro (Figura 9). Após isso cada paciente recebeu um pequeno pedaço de borracha de silicone ${\text { hiperbolóide* }{ }^{*} \text { Saudbucal }}^{\circledR}$ (Figura 10a), o qual foi usado para estimular a salivação através da mastigação (fluxo salivar com estímulo) por 5 minutos, vertendo toda a saliva obtida também em um recipiente de vidro (Figura 10b), e medida da mesma forma que no procedimento anterior. A quantidade de saliva, em ambos os testes, foi obtida através de seringa plástica descartável de 5 mililitros (Figura 10c).

\footnotetext{
* SaudBucal, HCL Representações e Comércio, Ltda.
} 


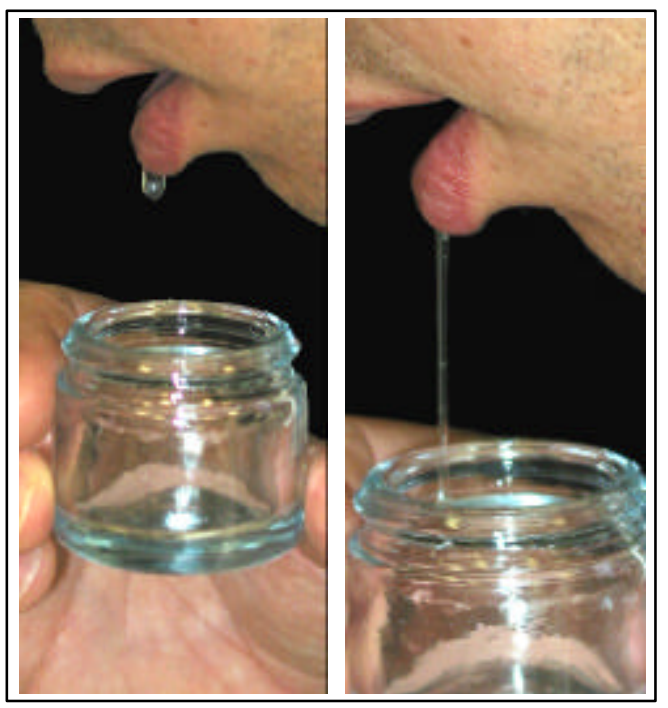

FIGURA 9 - Sialometria em repouso

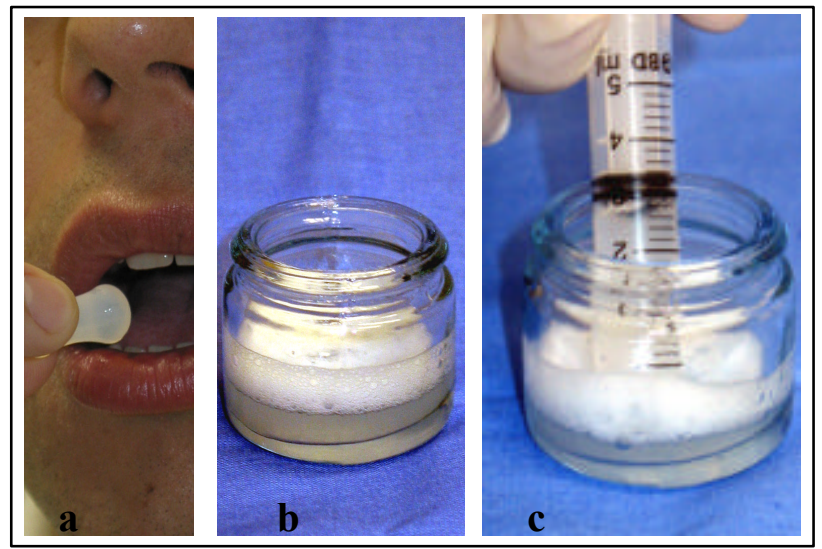

FIGURA 10- a)hiperbolóide sendo colocado na boca; b) obtenção da saliva, c) medição do volume salivar

\subsubsection{Questionário médico-odontológico}

O próximo passo foi o preenchimento de um questionário (apêndices 4 e 5) sobre as condições de saúde bucal e geral do paciente; foi realizado o exame intrabucal para a identificação de quaisquer fatores que influenciassem o hálito, ou patologias.

Aqueles pacientes pertencentes ao grupo de não fissurados que apresentaram alterações odontológicas, relativos ou não ao hálito, foram encaminhados às clínicas da Faculdade de Odontologia de Bauru - USP para atendimento. Os pacientes fissurados que por ventura apresentaram alguma alteração odontológica foram 
encaminhados às clínicas do setor odontológico do Hospital de Reabilitação de Anomalias Craniofaciais - USP.

Os resultados foram analisados utilizando-se o teste $\mathrm{t}$ pareado nas variáveis que quantificaram o hálito antes e após a remoção da sabura e com expiração forçada. As relações entre halimetria bucal, peso seco da saburra, fluxo salivar com e sem estímulo, halimetria nasal, e a relação entre fluxo salivar em repouso e estimulado foram feitas através do teste de correlação de Pearson. Para verificar correlações entre halimetria bucal inicial e autopercepção do hálito e halimetria bucal inicial e teste BANA $^{\mathrm{TM}}$ foi utilizado o coeficiente de correlação de Spearman. As relações entre as variáveis dos grupos 1 e 2 foram avaliadas através do teste $t$ independente. Em todos os casos foi adotado nível de significância de 5\%.

As orientações sobre os dados estatísticos foram realizadas junto à disciplina de Bioestatística da FOB. 


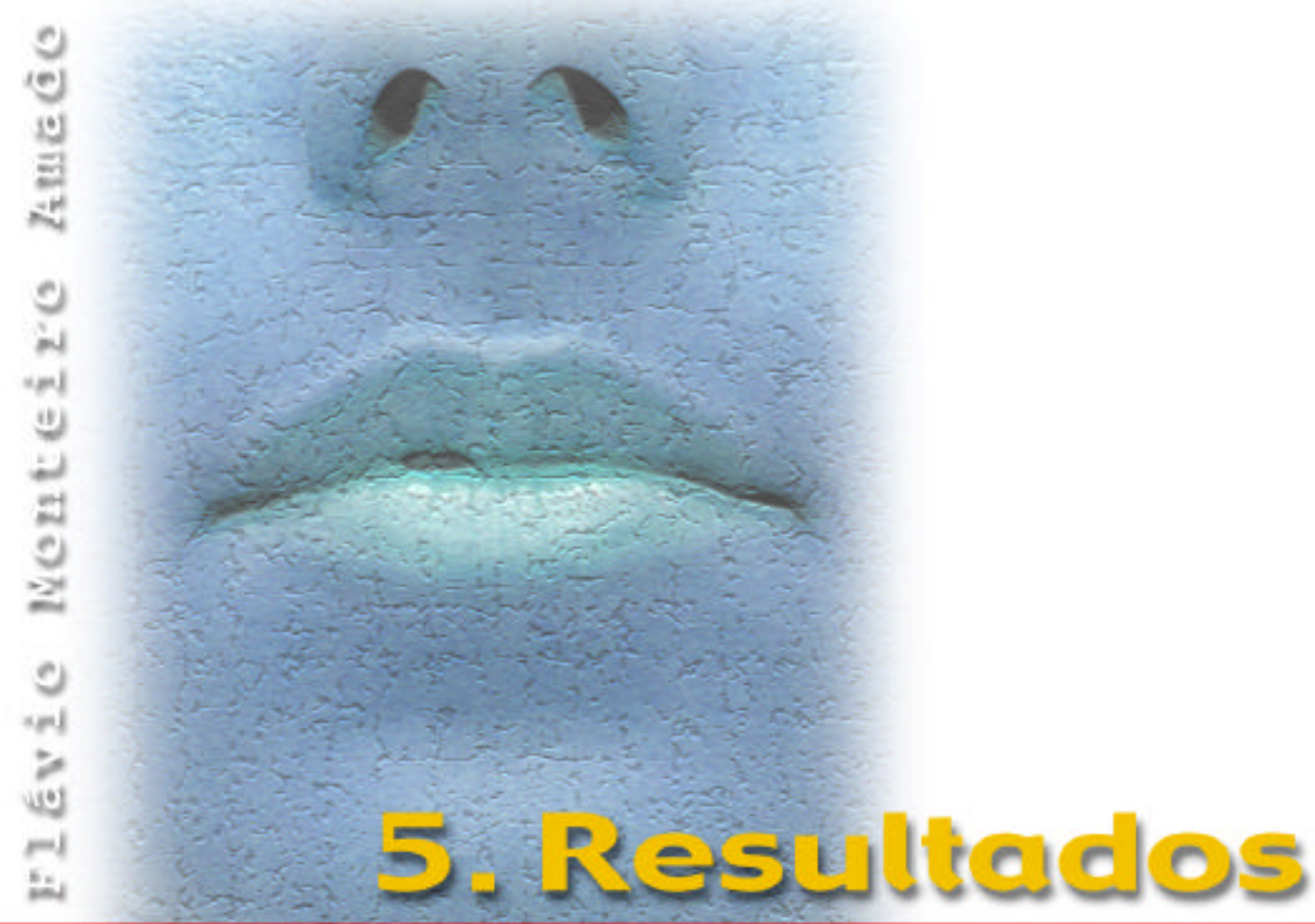




\section{5-RESULTADOS}

Foram avaliados 42 pacientes divididos em dois grupos de 21 pacientes cada: grupo 1, sem fissura de lábio e/ou palato; grupo 2, portadores de fissura de lábio e/ou palato reparada, sendo cada grupo constituído por 8 mulheres e 13 homens.

No grupo 1,14 pacientes apresentaram historia de problemas de saúde geral, de acordo com a anamnese, distribuídos da seguinte forma: sinusite (1), rinite (8), digestivo (2), intestinal (2), alergia (4), ginecológico (2), hepático (1), pulmonar (2). Alguns pacientes apresentaram mais de 1 alteração.

No grupo 2, 12 pacientes apresentaram historia de problemas de saúde geral, de acordo com a anamnese, distribuídos da seguinte forma: rinite (6), digestivo (4), renal (1), circulatório (1), pulmonar (1). Nenhum paciente apresentou mais de 1 alteração.

As avaliações dos parâmetros avaliados neste estudo estão apresentadas nas tabelas seguintes. Sempre que houver resultado estatisticamente significante quanto ao teste de correlação de Pearson um gráfico será apresentado, para uma melhor compreensão.

Utilizaremos a seguir as seguintes abreviaturas:

H1- halimetria inicial (ppb)

H2- halimetria após a remoção da saburra (ppb)

H3- halimetria com expiração forçada (ppb)

HN- halimetria nasal (ppb)

SAB- $\quad$ peso seco da saburra $(\mathrm{mg})$

SREP- fluxo salivar em repouso $(\mathrm{mL})$

SEST- fluxo salivar com estímulo (mL)

AP- auto percepção do hálito

Valores em negrito foram estatisticamente significantes para $\mathrm{p}<0,05$. 
TABELA 2 - Resultados do teste $t$ pareado para a relação entre as variáveis H1 e $\mathrm{H} 2$, e $\mathrm{H} 1$ e $\mathrm{H} 3$, do grupo 1

\begin{tabular}{c|c|c|c|c|c|c}
\hline VARIÁVEL & MÉDIA & D.P. & VARIÁVEL & MÉDIA & D.P. & p \\
\hline H1 & 88,9523 & 73,9624 & H2 & 69,4761 & 38,0928 & $\mathbf{0 , 0 4 7 4}$ \\
\hline H1 & 88,9523 & 73,9624 & H3 & 56,2857 & 25,0342 & $\mathbf{0 , 0 1 2 2}$ \\
\hline
\end{tabular}

TABELA 3 - Resultados do teste t pareado para a relação entre as variáveis H1 e H2, e H1 e H3, do grupo 2

\begin{tabular}{c|c|c|c|c|c|c}
\hline VARIÁVEL & MÉDIA & D.P. & VARIÁVEL & MÉDIA & D.P. & p \\
\hline H1 & 91,8095 & 68,8764 & H2 & 66,1428 & 51,7003 & $\mathbf{0 , 0 2 5 0}$ \\
\hline H1 & 91,8095 & 68,8764 & H3 & 65,9047 & 68,8737 & 0,0837 \\
\hline
\end{tabular}

TABELA 4 - Resultados do teste t pareado para a relação entre as variáveis H1 e H2, e $\mathrm{H} 1$ e H3, de todos os pacientes agrupados

\begin{tabular}{c|c|c|c|c|c|c}
\hline VARIÁVEL & MÉDIA & D.P. & VARIÁVEL & MÉDIA & D.P. & p \\
\hline H1 & 90,3809 & 70,6026 & H2 & 67,8095 & 44,8837 & $\mathbf{0 , 0 0 4 3}$ \\
\hline H1 & 90,3809 & 70,6026 & H3 & 61,0952 & 51,4135 & $\mathbf{0 , 0 0 5 9}$ \\
\hline
\end{tabular}

TABELA 5 - Resultados do teste $t$ independente entre as variáveis dos grupos 1 e 2

\begin{tabular}{c|c|c|c|c|c|c}
\hline \multirow{2}{*}{ VARIÁVEIS } & \multicolumn{2}{|c|}{ COM FISSURA } & \multicolumn{2}{c|}{ SEM FISSURA } & \multirow{2}{*}{ Dif. } & \multirow{2}{*}{ p } \\
\cline { 2 - 5 } & MÉDIA & D.P. & MÉDIA & D.P. & & \\
\hline H1 & 91,8095 & 68,8764 & 88,9523 & 73,9624 & $-2,8571$ & 0,8975 \\
\hline H2 & 66,1428 & 51,7003 & 69,4761 & 38,0928 & 3,3333 & 0,8132 \\
\hline SAB & 0,0235 & 0,0150 & 0,0139 & 0,01332 & $-0,0096$ & $\mathbf{0 , 0 3 3 5}$ \\
\hline H3 & 65,9047 & 68,8737 & 56,2857 & 25,0342 & $-9,6190$ & 0,5508 \\
\hline SREP & 0,1628 & 0,1395 & 0,1790 & 0,1275 & 0,01619 & 0,6967 \\
\hline SEST & 1,2466 & 0,9382 & 1,1695 & 0,7022 & $-0,0771$ & 0,7644 \\
\hline HN & 47,6666 & 13,9044 & 62,0000 & 20,1940 & 14,3333 & $\mathbf{0 , 0 1 0 6}$ \\
\hline
\end{tabular}


TABELA 6 - Resultados do teste de correlação de Pearson entre as variáveis com possíveis relações causais com a halitose, no grupo 1

\begin{tabular}{c|c|c}
\hline VARIÁVEIS & r & p \\
\hline H1 1 SAB & 0,3104 & 0,1707 \\
\hline H1 1 SREP & $-0,0283$ & 0,9030 \\
\hline H1 $\times$ SEST & $-0,1258$ & 0,5868 \\
\hline H1 $\times$ HN & $-0,2512$ & 0,2719 \\
\hline SAB X SREP & $-0,2051$ & 0,3724 \\
\hline SAB x SEST & $-0,0666$ & 0,7742 \\
\hline SREP x SEST & 0,4025 & 0,0704 \\
\hline
\end{tabular}

TABELA 7 - Resultados do teste de correlação de Pearson entre as variáveis com possíveis relações causais com a halitose, no grupo 2

\begin{tabular}{c|c|c}
\hline VARIÁVEIS & r & p \\
\hline H1 x SAB & 0,6924 & $\mathbf{0 , 0 0 0 5}$ \\
\hline H1 x SREP & 0,4523 & $\mathbf{0 , 0 3 9 5}$ \\
\hline H1 x SEST & 0,5595 & $\mathbf{0 , 0 0 8 3}$ \\
\hline H1 x HN & 0,3929 & 0,0780 \\
\hline SAB X SREP & 0,4470 & $\mathbf{0 , 0 4 2 1}$ \\
\hline SAB x SEST & 0,7215 & $\mathbf{0 , 0 0 0 2}$ \\
\hline SREP X SEST & 0,5819 & $\mathbf{0 , 0 0 5 6}$ \\
\hline
\end{tabular}

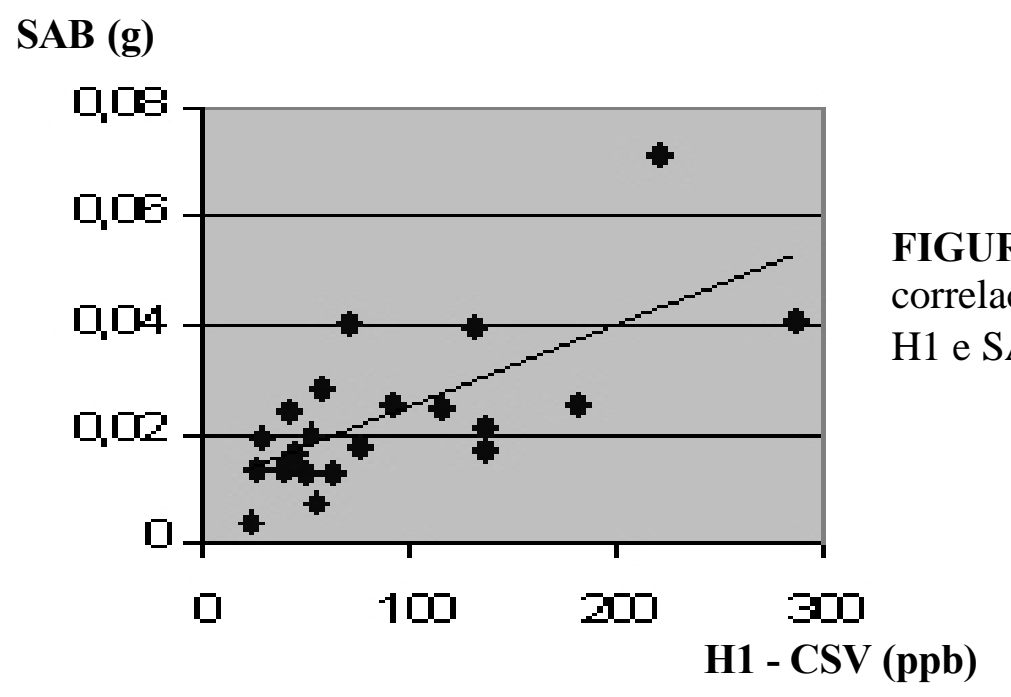



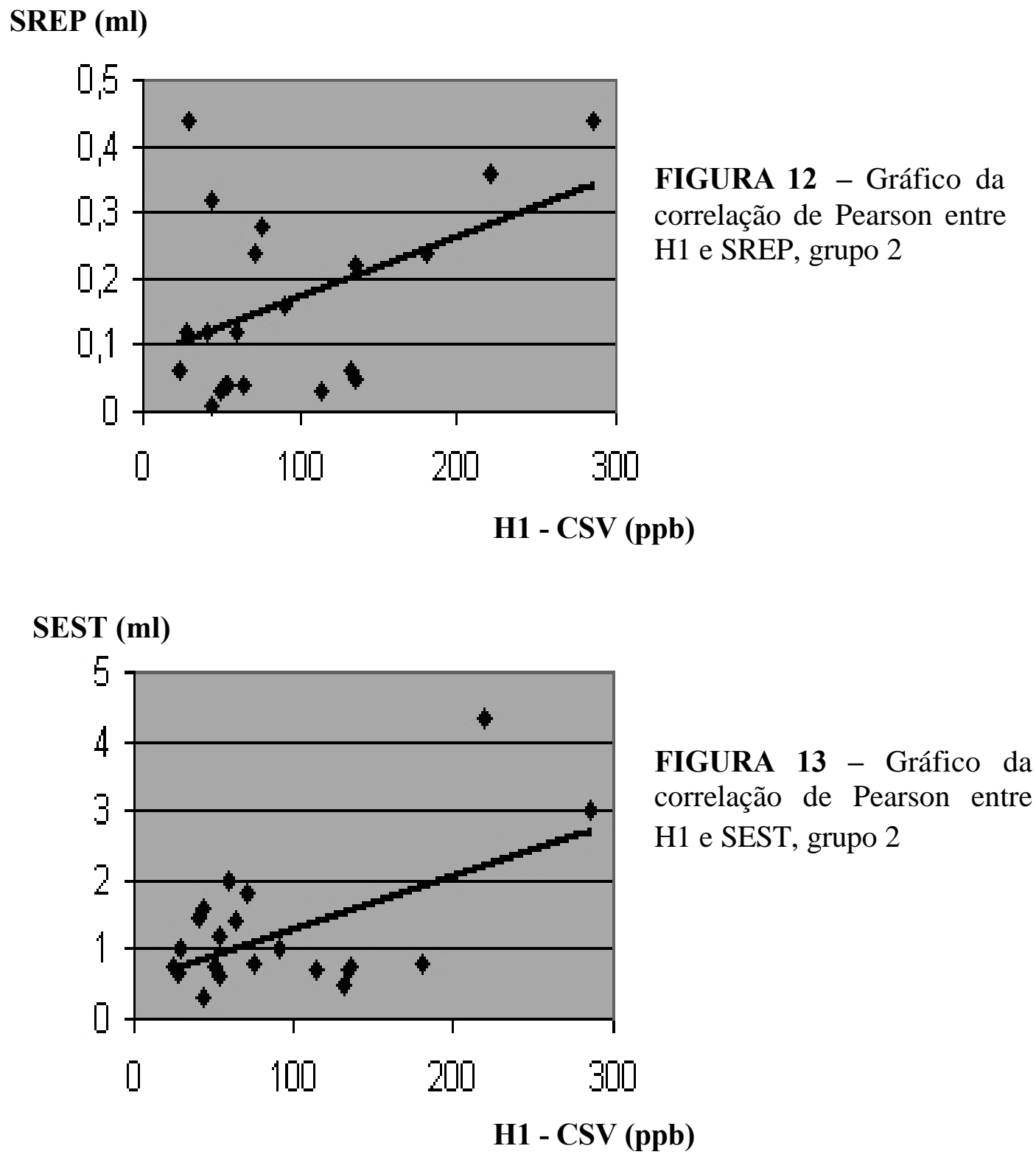

\section{SREP(ml)}

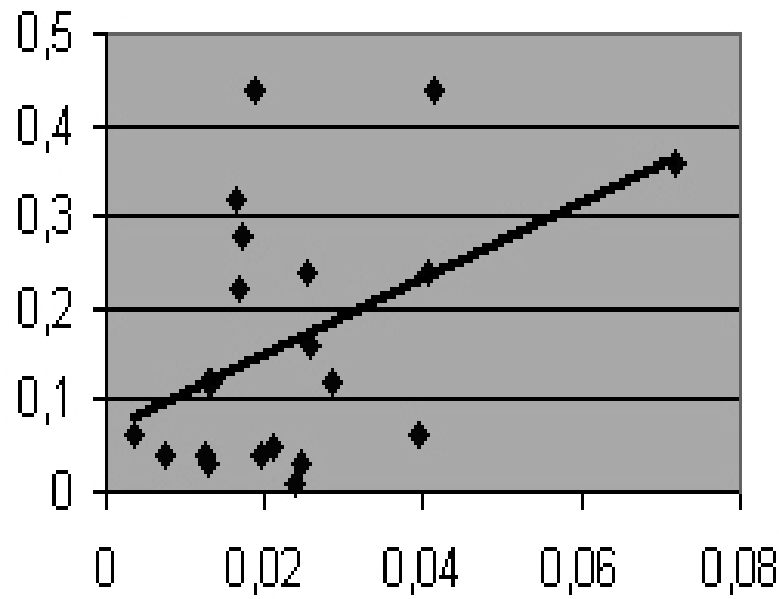

FIGURA 14 - Gráfico da correlação de Pearson entre SREP e SAB, grupo 2 


\section{$\operatorname{SEST}(\mathbf{m l})$}

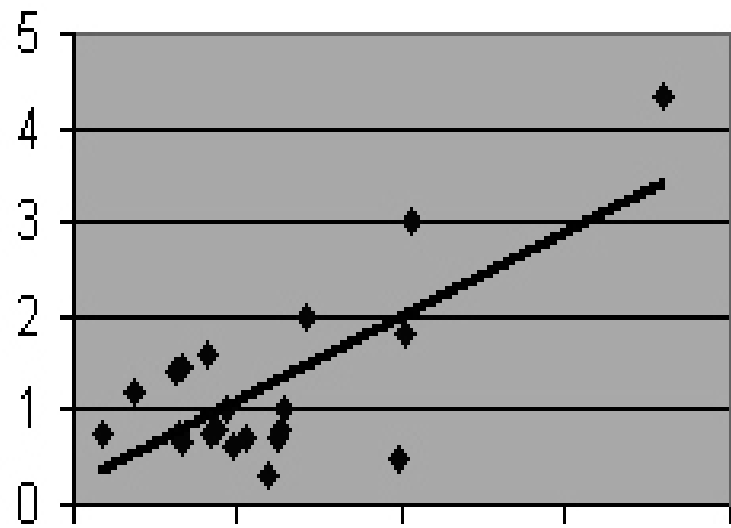

$\begin{array}{lllll}0 & 0,02 & 0,04 & 0,06 & 0,00\end{array}$

SAB (g)

\section{$\operatorname{SEST}(\mathbf{m l})$}

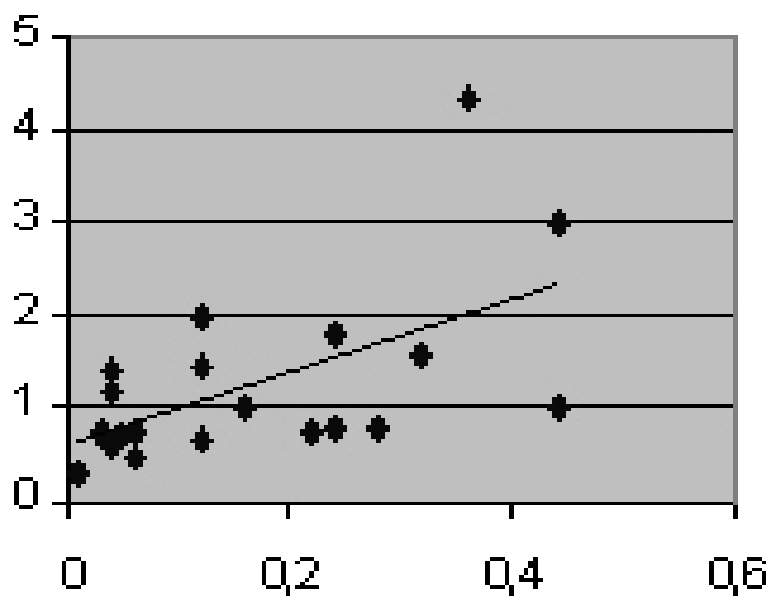

FIGURA 15 - Gráfico da correlação de Pearson entre SEST e SAB, grupo 2

FIGURA 16 - Gráfico da correlação de Pearson entre SREP e SEST, grupo 2

\section{$\operatorname{SREP}(\mathbf{m l})$}

TABELA 8 - Resultados do teste de correlação de Pearson entre as variáveis com possíveis relações causais com a halitose, de todos os pacientes agrupados

\begin{tabular}{c|c|c}
\hline VARIÁVEIS & r & p \\
\hline H1 $\times$ SAB & 0,4824 & $\mathbf{0 , 0 0 1 2}$ \\
\hline H1 XREP & 0,211871 & 0,1779 \\
\hline H1 $\times$ SEST & 0,2507 & 0,1092 \\
\hline H1 XN & $-0,0076$ & 0,9618 \\
\hline SAB X SREP & 0,1259 & 0,4266 \\
\hline SAB x SEST & 0,3985 & $\mathbf{0 , 0 0 8 9}$ \\
\hline SREP X SEST & 0,5021 & $\mathbf{0 , 0 0 0 7}$ \\
\hline
\end{tabular}




\section{SAB (g)}

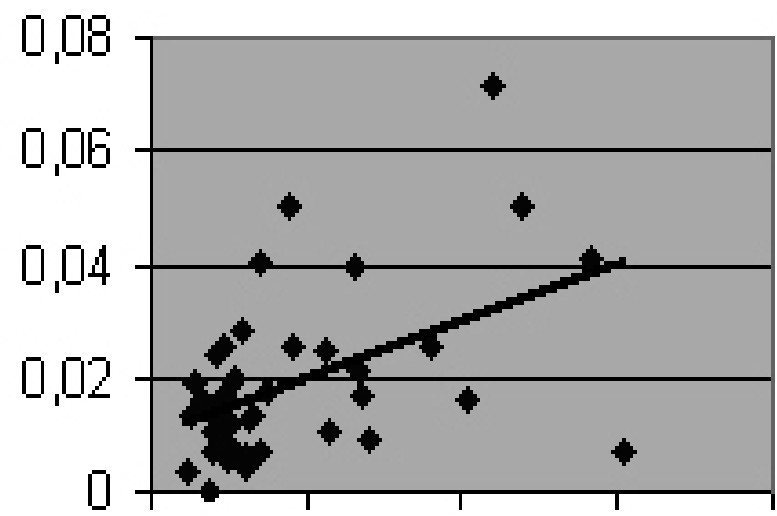

FIGURA 17 - Gráfico da correlação de Pearson entre $\mathrm{H} 1$ e SAB, de todos os pacientes agrupados

$\begin{array}{lllll}0 & 100 & 200 & 300 & 400\end{array}$

H1 - CSV (ppb)

\section{$\operatorname{SEST}(\mathrm{ml})$}

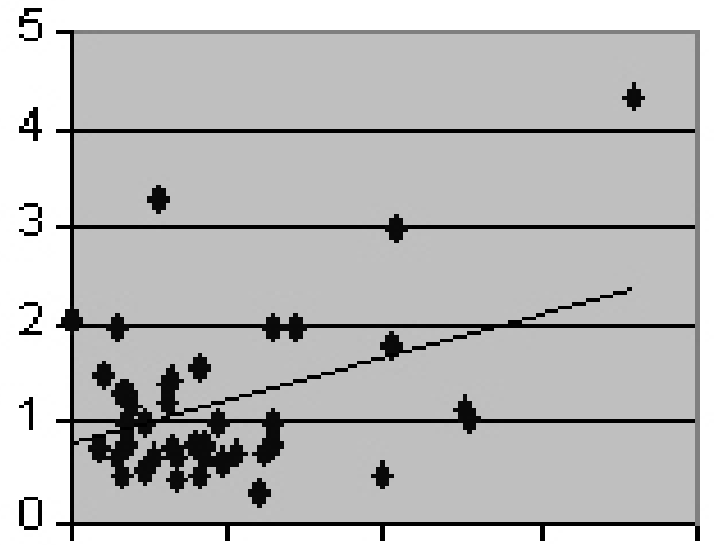

FIGURA 18 - Gráfico da correlação de Pearson entre SEST e SAB, de todos os pacientes agrupados

\section{$\begin{array}{lllll}0 & 0,02 & 0,04 & 0,06 & 0,08\end{array}$}

SAB (g)

\section{$\operatorname{SEST}(\mathbf{m l})$}

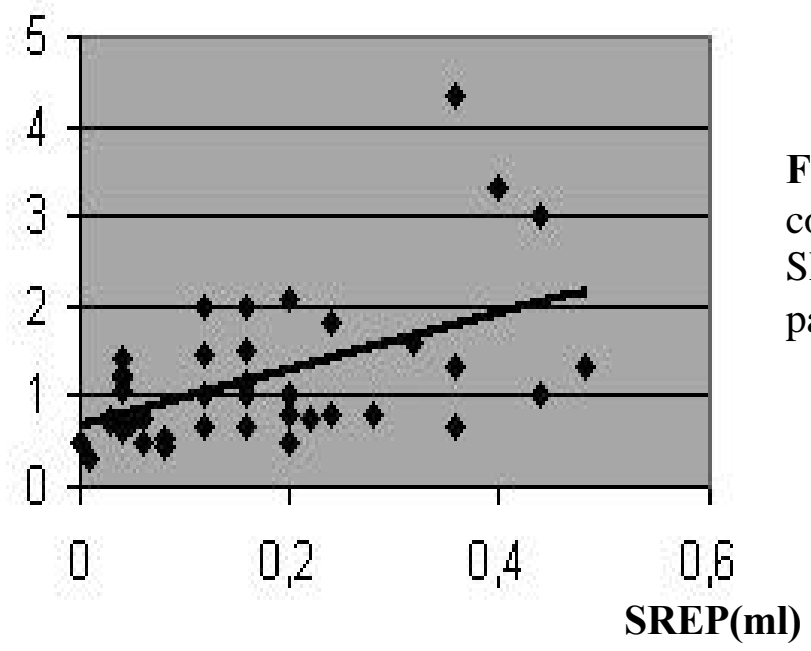

FIGURA 19 - Gráfico da correlação de Pearson entre SEST e SREP, de todos os pacientes agrupados 
TABELA 9 - Resultados do teste de correlação de Spearman entre H1 e BANA e H1 e AP, de todos os pacientes agrupados

\begin{tabular}{c|c|c}
\hline VARIÁVEIS & r & p \\
\hline H1 x AP & 0,1032 & 0,5152 \\
\hline H1 x BANA & 0,1854 & 0,2396 \\
\hline
\end{tabular}




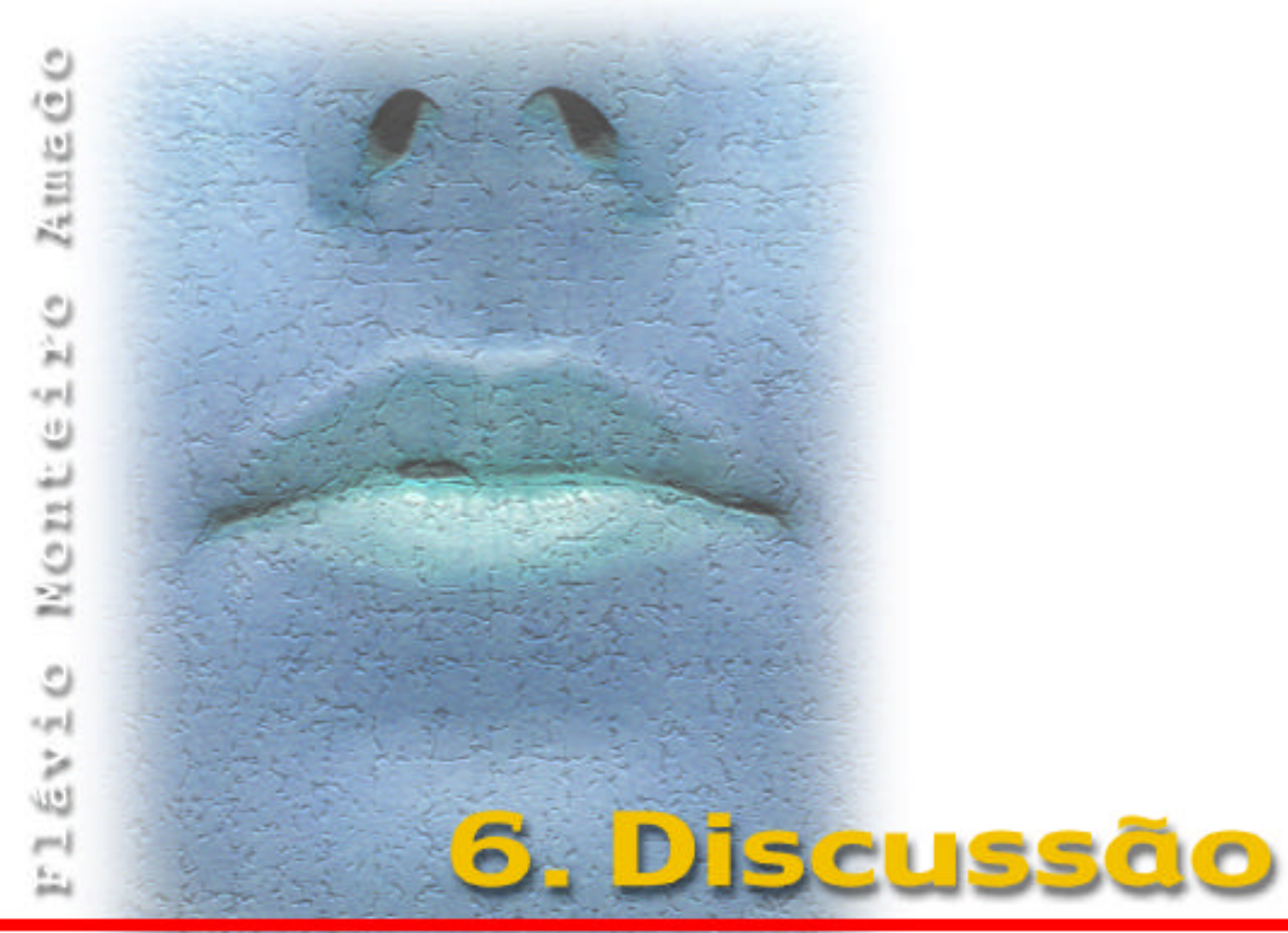




\section{6-DISCUSSÃO}

Uma grande dificuldade observada durante a pesquisa necessária a este trabalho foi o excesso de publicações descrevendo o processo de formação do hálito, sua identificação e tratamento, que não eram fruto de observações científicas, e sim de pesquisa bibliográfica ou observações clínicas. A quantidade de artigos apenas discursivos se equipara ao número de publicações científicas no que concerne ao assunto envolvido neste trabalho. Apenas aquelas observações pertinentes foram tomadas em consideração e, desta forma, muitos artigos que fazem parte da bibliografia deste estudo são apenas citados, restritos apenas às observações relevantes.

Acredita-se que pelo menos $50 \%$ da população sofra de mau hálito crônico ${ }^{14}$. A etiologia da halitose se localiza na boca em mais de $90 \%$ das pessoas com o problema ${ }^{112}$. O mau hálito e comumente o resultado de putrefação microbiana de partículas de alimentos, células, saliva e sangue na cavidade bucal. Em particular, lise de proteínas a peptídeos e aminoácidos, e então para substratos com grupos tióis livres, como cisteína e glutationa reduzida, que originam os CSVs, como sulfeto de hidrogênio e metil mercaptanas. A intensidade do mau hálito está significantemente relacionada com o aumento nos níveis intra-bucais dos $\mathrm{CSVs}^{85}$, mas compostos voláteis não sulfurados, incluindo acetona, acetaldeído, etanol, propanol e diacil, podem estar envolvidos na formação do hálito, assim como a cadaverina, uma diamina volátil produto de degradação da saliva que é originada pela descarboxilação da lisina ${ }^{90}$, e pode ser um importante componente do mau cheiro ${ }^{74}$.

Oitenta e duas espécies de bactérias têm sido implicadas na produção de compostos com mau cheiro. Fatores que contribuem para a produção, liberação e detecção destes odores são o fluxo salivar reduzido, estagnação da saliva, baixa concentração de oxigênio ambiente, reduzido carboidrato disponível como substrato bacteriano e um aumento do $\mathrm{pH}$ bucal12, 114. Pensa-se que as bactérias gramnegativas são as grandes responsáveis, produzindo altos níveis de $\mathrm{CSV}_{\mathrm{s}}{ }^{14}$. 
Qualquer sítio intra-bucal onde haja impacção alimentar pode produzir mau cheiro. Os sítios comuns incluem o dorso da língua, áreas subgengivais e interdentais e restaurações defeituosas ${ }^{5}$, sendo que a fonte mais provável de mau-hálito em indivíduos com boa higiene bucal e tecidos periodontais saudáveis é a parte posterior da língua 71 .

O nível geral de conhecimento quanto às causas de halitose e seu manuseio, contudo, não é alto entre a maioria dos pacientes odontológicos e nem entre médicos e dentistas 26 . O tratamento da halitose não deveria ser considerado apenas como terapia cosmética, pois evidências indicam que muitos membros da família dos CSVs são tóxicos a tecidos bucais, mesmo em baixas concentrações ${ }^{78}$. Isto demonstra a necessidade de uma melhor compreensão deste fenômeno.

Todavia, a percepção de odores é um processo complexo. Cheiro tem sido descrito como gosto à distância, e sua similaridade com o gosto se baseia no fato de que ambos são percepções químicas ${ }^{68}$. A complexidade de mais este fenômeno se torna um fator complicador no estudo das alterações do hálito.

\section{1-Delineamento do Estudo}

A atividade putrefativa na cavidade bucal é a principal causa de halitose. A condição é mais prevalente na meia-idade e senescência, com o mau-hálito mais intenso ocorrendo imediatamente ao levantar pela manhã. O reconhecimento de alguns tipos de odor, entretanto, podem ser um auxílio diagnóstico valioso na detecção de doenças sistêmicas. ${ }^{115}$. Já em 1941 CROHN; DROSD 29 observaram que substâncias odoríferas voláteis poderiam fazer a rota do intestino para o fígado, daí para os pulmões e então para o hálito.

Estudos posteriores demonstraram uma relação positiva entre as medidas organolépticas do hálito e os valores de CSVs obtidos através de monitor de sulfetos $^{72,76}$, o que nos estimulou ao uso do monitor Halimeter ${ }^{\mathrm{TM}}$ para a realização deste estudo. 
Sendo que a sociedade geralmente reage negativamente à deformação facial $^{20}$, e a halitose pode ser um fator socialmente negativo a mais na vida dos indivíduos portadores de deformidades, este estudo foi realizado com o intuito de observar as diferenças em relação aos parâmetros de halitose em pacientes com fissura de lábio e/ou palato e pacientes sem fissura, propiciando a obtenção de dados que permitissem o delineamento dos fatores que pudessem modificar o hálito de um grupo em detrimento de outro.

\section{2-Seleção da Amostra}

Procuramos em nosso trabalho tomar o grupo de alunos de pós-graduação em odontologia como grupo controle, visto que é uma população mais informada sobre os hábitos adequados de higiene bucal. Corroborando com nosso procedimento o estudo de FIGUEIREDO et al. ${ }^{40}$ relatou, em 2002, em estudo sobre halitose em pacientes com e sem doença periodontal, que níveis absolutos de CSVs podem variar entre diferentes grupos populacionais, e que estudos sobre a produção de CSVs devem possuir população controle que não possua doença periodontal ou queixa de halitose .

\section{3-Metodologia}

O interesse pela compreensão da halitose é grande. Diferentes metodologias já foram estudadas para a determinação do hálito, como a utilização de osmoscópio e crioscópio ${ }^{16}$, espectrometria de massa ${ }^{83}$, substâncias redutoras voláteis ${ }^{117}$, cromatografia gasosa $62,76,98,103$, monitor portátil de sulfetos $86,126,128$. Além disso, a tentativa de determinar as possíveis causas da halitose também vem de longa data, com o estudo da influência da doença periodontal ${ }^{9}$, das condições gerais de saúde bucal ${ }^{104}$ e da escovação dos dentes ${ }^{105}$.

CROHN; DROSD29, em 1941, afirmaram que "A menos que existam condições patológicas bucais ou nasofaringeanas, a boca, os dentes, a faringe ou o estômago exercem um pequeno ou nenhum papel na produção da halitose 
essencial'. Por definição, halitose essencial é aquela em que a etilogia é extrabucal, mas desconhecida, e que reflete alguma doença interna. Contudo, a maioria das publicações científicas identifica a boca como a maior fonte de odor desagradável, o que torna o estudo das causas bucais da halitose o caminho mais óbvio na tentativa de buscar soluções para este problema. Este odor local, oriundo das condições bucais e cavidades associadas (nariz, seios paranasais e faringe) pode ser referido como fetor ex ore ou fetor oris.

Estudos em cães também têm sido realizados com o intuito de estimar alguns dos fatores que afetam o mau-hálito, como problemas periodontais ${ }^{79}$, higiene bucal $^{80}$, corpo estranho na nasofaringe 63 e infecções bucais 92 .

Entretanto, a quantificação do mau-hálito é um problema que tem limitado as investigações científicas sobre suas causas e tratamentos. As medidas intrabucais com monitor de sulfetos oferecem dados quantitativos rápidos que são reproduzíveis e sensíveis, fáceis de utilizar e relativamente baratos 61 .

A avaliação de odor por juízes possui vários obstáculos, como falta de padrões adequados para calibração, teste, treinamento e comparação entre os juízes ${ }^{85}$, portanto, um utensílio para medições simples e objetivas é necessário para pesquisa e avaliação clínica. 102

ROSENBERG et al. ${ }^{86}$ afirmaram que o monitor de sulfetos pode ser uma ferramenta para a avaliação do hálito, baseado na superior reprodutibilidade e sensibilidade das mensurações de sulfetos, comparado às medidas organolépticas, sendo que o monitor tem ainda as vantagens de não exigir habilidade, não é invasivo, não oferece a possibilidade de infecção cruzada, é portátil, relativamente barato e oferece medidas rápidas.

A obtenção da história médica completa é obrigatória para identificar condições sistêmicas que possam contribuir para a halitose ${ }^{14}$. Em estudos sobre o hálito, a escolha dos critérios de exclusão (fumo, fatores da dieta, medicação, época 
do ano e tratamento odontológico) deve ser considerada, pois diminuem as variáveis dos dados obtidos. Entretanto, também restringem os achados às subclasses de indivíduos examinados ${ }^{85}$ podendo não refletir a condição real de uma população.

Embora o hálito desagradável possa ocorrer devido a toda variedade de desordens orgânicas ${ }^{101}$, limitamos as variáveis desta pesquisa aos valores de fluxo salivar, teste BANA ${ }^{\mathrm{TM}}$, halimetria bucal e nasal e peso seco da saburra, não tendo o intuito de avaliar a influência do estado periodontal do paciente nos valores medidos, visto que os mesmos foram obtidos antes e após a remoção da saburra, objetivando, desta forma, relacionar tão exclusivamente esta variável aos dados obtidos.

\section{4-Discussão dos Resultados}

\subsection{1-Halimetria}

Até recentemente acreditava-se que não há mé todos convenientes para medir o hálito, pela falta de um "gold standard" 26 . Mais ainda, enquanto grande parte de medições diagnósticas é feita em estado de equilíbrio, as medições com o Halimeter $^{\mathrm{TM}}$ são obtidas em ambiente perturbado, criado pelo próprio instrumento ${ }^{42}$, devido à movimentação do ar para o interior do aparelho, e o mesmo não é calibrado com padrões de concentrações conhecidas ${ }^{42}$. Tal afirmação poderia colocar em descrédito a utilização de uma me todologia que se utilize de um monitor como este para a avaliação do hálito, mas deve-se lembrar que o tipo de calibração realizado para o Halimeter $^{\mathrm{TM}}$ (amostragem de pacientes normais, sem hálito detectável) não é único, sendo utilizado comumente em biologia.

Medições de CSVs com o Halimeter ${ }^{\mathrm{TM}}$ subestimam as concentrações dos gases bucais ${ }^{42}$, pois: o Halimeter ${ }^{\mathrm{TM}}$ dilui as concentrações dos gases bucais na medida em que aspira o ar ambiente para a boca; responde lentamente para uma medição precisa da verdadeira concentração de gases; o Halimeter ${ }^{\mathrm{TM}}$ tem baixa resposta a alguns CSVs medidos pela cromatografia gasosa (dimetil sulfeto e dissulfeto de carbono $)^{85}$. 
Neste estudo avaliou-se exclusivamente a relação dos CSV com a halitose, o que representa uma limitação da metodologia, já que em alguns casos o mau-hálito é composto por diferentes compostos orgânicos voláteis 93 e também outros gases ${ }^{47}$.

SPRINGFIELD 98 relatou que a inerente variabilidade na concentração de CSVs no gás bucal tem implicações para o uso das medições de enxofre para a avaliação da halitose. O presente estudo limita-se no fato de que diferentes momentos do dia foram utilizados para a obtenção dos valores de CSV bucais e nasais.

\subsubsection{1-Halimetria Bucal}

O grupo 1 mostrou maiores valores de halimetria bucal do que o grupo 2, porém, sem diferença estatisticamente significante. Entretanto, apesar de os pacientes portadores de fissura serem propensos a possuir lesões periodontais mais extensas do que a população em geral ${ }^{43}$, e de haver relação estreita entre doença periodontal e halitose $9,27,60,61,71,73,78,112,114,129$, não podemos afirmar a exata causa deste achado, visto que a situação periodontal dos pacientes não foi avaliada metodologicamente. Pode-se apenas afirmar que comprometimento periodontal não foi evidente em nenhum dos grupos, quando considerada a sua avaliação clínica estritamente visual.

\subsubsection{2-Halimetria Nasal}

A tarefa do clínico é avaliar a origem do mau-hálito do paciente e oferecer um regime de tratamento adequado ${ }^{14}$. Para tal, é necessária uma completa compreensão dos aspectos envolvidos na formação do hálito.

As vias aéreas são a $2^{\mathrm{a}}$ maior causa de halitose ${ }^{32}$. Tonsilite, rinite e sinusite podem contribuir para a halitose ${ }^{53}$, além de pólipos e corpos estranhos nas vias aéreas ${ }^{14}$. MESSADI relatou que qualquer corpo estranho presente no nariz induz uma resposta nflamatória. O local afetado pode ser infectado secundariamente, e 
produzir mau cheiro. Criptas amigdalianas profundas guardam alimento, saliva e material necrótico. Se tal matéria não é limpa por mecanismos naturais, formam tonsilolitos, que são concreções apoiadas em base inflamatória que eventualmente causam halitose ${ }^{71}$.

O odor nasal pode ser indicativo de infecção nasal, como sinusite, ou de problemas que afetam o fluxo aéreo ou secreção de muco ${ }^{84}$, e a remoção de adenóides e amídalas já foi, inclusive, proposta para o tratamento da halitose ${ }^{30}$.

Apesar destas observações, não encontramos trabalhos que estudaram a halitose nasal e suas causas. Afirmações sobre a ocorrência de mauthálito em pacientes portadores de deformidades faciais se devem a relatos clínicos e suposições $^{5,41}$.

A fissura de lábio e/ou palato é uma das malformações congênitas mais comuns. Contudo, sua etiologia ainda não é completamente compreendida 58 . Anomalias craniofaciais, como fissura palatal, atresia coanal lateral e tumores da cavidade nasal, oferecem um ambiente alterado susceptível a infecções e produção de cheiro desagradável ${ }^{5}$. Paciente portadores de fissura de lábio e/ou palato podem ainda apresentar impedimento severo da respiração nasal, como resultado de menor área de secção transversal das passagens aéreas nasais ${ }^{127}$. Isto nos levou a pensar que um menor fluxo aéreo na região favoreceria o crescimento de microorganismos gram-negativos proteolíticos, produtores de CSVs, devido ao baixo nível de oxigênio. Entretanto, o que observamos foram maiores valores de halimetria nasal nos pacientes do grupo $1 \mathrm{sem}$, contudo, conseguirmos inferir para o fato uma causa aparente.

MESSADI $^{71}$ afirmou que se odor forte se origina do nariz, isso indica a existência de lesões ou doenças do nariz, nasofaringe e seios paranasais. Em nosso estudo a maioria dos pacientes se manteve com baixos níveis de CSVs nasais, e apesar do grupo 1 apresentar valores maiores, mantiveram-se dentro de valores aceitáveis em uma faixa de normalidade. 


\subsection{2-Peso da Saburra}

WALER ${ }^{126}$ demonstrou que a maior atividade de produção de CSVs é no dorso lingual.

DE BOEVER; LOESCHE ${ }^{31}$ avaliaram a quantidade de saburra visualmente, e notaram que o escore de hálito bucal esteve altamente associado ao odor da língua, presença e extensão da saburra. Em nosso estudo, porém, a quantidade de saburra foi avaliada quantitativamente (peso), o que vai de encontro à metodologia utilizada por YAEGAKI; SANADA ${ }^{129}$.

Nossas observações reforçam a idéia de que a limpeza adequada da língua deva ser parte da rotina de higiene diária ${ }^{84}$, visto que a remoção da saburra diminuiu os níveis de CSVs bucais, tanto no grupo 2, como após o agrupamento de todos os pacientes, com uma correlação de média a alta. Entretanto tal pensamento não é consensual, visto que alguns autores 7,70 afirmam que tal ato não reduz significantemente a população bacteriana, e outros ${ }^{45}$ afirmam que a correta limpeza da língua, diariamente, modifica o população bacteriana da língua e afeta a taxa de formação de placa bacteriana in vitro.

Nesta pesquisa escolhemos o limpador de língua para a remoção da saburra pois é de fácil manuseio e gera menor estímulo para os reflexos de ânsia ${ }^{23}$. Os dados obtidos com a remoção da saburra nos levam a concordar que a limpeza da língua é uma etapa importante para a diminuição dos níveis de CSVs bucais, visto que houve diminuição dos valores de halimetria após a limpeza da língua. 


\subsection{3-Teste BANA ${ }^{\mathrm{TM}}$}

Alguns autores não observaram relação ente os níveis de CSVs e os resultados do teste $\mathrm{BANA}^{\mathrm{TM}}$ lingual ${ }^{128}$. No presente estudo não houve relação entre o valor do $\mathrm{BANA}^{\mathrm{TM}}$ e os valores de halimetria.

Nossas observações a partir dos resultados do teste BANA devem ser tomadas com cautela. É sabido que a sensibilidade, especificidade e acurácia do teste podem variar de acordo com as condições dos exames, como a forma de incubação ${ }^{1,65}$. Além disso, no presente estudo avaliamos pacientes sem queixa de halitose e boas condições de higiene. É possível que esta relação entre BANA e halitose se torne clara à medida em que a halitose passe a ser uma queixa do paciente, e à medida em que a quantidade de saburra aumente, o que propicia a proliferação de microorganismos anaeróbios.

\subsection{4-Fluxo salivar}

Pobre higiene bucal é provavelmente o fator mais comum que leva ao mauhálito e tende a exacerbar o hálito causado pelo fumo. Pacientes com boca seca freqüentemente reclamam de halitose, particularmente se há pobre higiene bucal. Condições que causam xerostomia incluem síndrome de Sjögren, radioterapia, diabetes e qualquer doença que resulte em febre alta ou desidratação, além de ingestão de medicamentos 130 .

Desidratação também resulta em decréscimo no fluxo salivar e aumento do hálito. A mastigação de alimentos leva ao aumento do fluxo salivar e tem ação detergente que geralmente reduz ou elimina ou mauthálito 81 .

Acredita-se que a saliva e tecidos moles bucais armazenam quantidades significantes de CSVs absorvendo-os antes que volatilizem. Isto faz com que a concentração de CSVs no ar bucal em qualquer momento possa não representar a taxa instantânea de geração de CSVs na boca ${ }^{82}$. 
Quando o paciente está dormindo ou não está comendo, o fluxo salivar cai e a saliva estagnada lentamente muda. $\mathrm{O} \mathrm{pH}$ da saliva estagnada aumenta acima de 7,0 e ocorre quebra enzimática, deixando a própria saliva com cheiro. $\mathrm{O}$ movimento de maré da saliva é inibido, e alimento e epitélio acumulados se tornam substratos para a flora bucal ${ }^{74}$.

Substâncias voláteis se expressam mais fortemente depois que a solução em que se encontram evapora 125,124 , e o hálito se torna mais forte quando a boca fica seca ${ }^{84}$. A mastigação, contudo, aumenta o fluxo salivar, com concomitante limpeza da boca e redução do hálito ${ }^{114}$, o que pode ser mostrado pela inversa relação entre o hálito durante o dia e o fluxo salivar ${ }^{115}$.

Observamos uma correlação média, estatisticamente significante, entre o fluxo salivar e os valores da halimetria, tanto no grupo 2 como após o agrupamento de todos os pacientes em um único grupo, mostrando relação direta entre fluxo salivar e peso seco da saburra. Novamente, levando em consideração que os pacientes estudados não possuíam queixa de mauthálito, que os níveis de CSVs encontrados foram baixos e que a quantidade de saburra encontrada, em geral, foi pequena, podemos pensar que a inibição da formação de saburra pelo alto fluxo salivar não seja evidente quando a quantidade de saburra é pouca.

\subsection{5-Auto-Percepção do Hálito}

BOSY, em 1997, afirmou que há uma grande relação entre gosto e cheiro, claramente demonstrada pelos portadores de mauthálito que se tornam conscientes de sua condição através de gosto desagradável em suas bocas, apesar de não conseguirem sentir seu próprio hálito ${ }^{14}$. ROSENBERG et al. ${ }^{85}$ discordam desta afirmação. Disseram que indivíduos podem sentir gosto ruim na boca e erroneamente assumir que isto está associado ao mauthálito. Outros lembram que apenas uma vez no passado foram avisados que tinham mauthálito e ainda se preocupam com isto 85 . 
Um paciente com halitose rapidamente se acostuma a isto e então não mais detecta o odor ${ }^{53}$. Ainda que seja um problema real, pessoas que se queixam de possuir mau-hálito podem ter uma auto-percepção que não reflete achados objetivos $^{36}$.

O desconforto causado pela halitose é totalmente psicológico, e a condição é estigmatizada de forma exagerada pela sociedade ${ }^{82}$. Tal observação pode levar a concluir que o estudo deste assunto é importante tanto no âmbito da saúde orgânica e psicológica como em sua influência nas relações sociais dos indivíduos. As pessoas afligidas pelo mau-hálito freqüentemente sentem grande embaraço e desconforto sabendo que seu hálito é desagradável para os que estão à sua volta ${ }^{14}$.

Importante não apenas em relação à saúde física do organismo, o tema "halitose" dá origem a publicações no campo da psicologia, pois a idéia de possuir hálito desagradável, idéia esta real ou imaginária (denominada síndrome da referência olfatória, uma variação da hipocondríase ilusória monossintomática), pode limitar o contato social do indivíduo, levar a procedimentos médicos desnecessários e à interrupção ocupacional ou acadêmica ${ }^{13}$, e revisões sobre o assunto têm sido publicadas $13,56,77,119$.

Neste estudo não pudemos constatar nos pacientes avaliados situações de halitofobia, visto que os pacientes selecionados não possuíam queixa de halitose. Apesar disso, alguns pacientes apresentaram valores altos de halimetria, enquanto outros mostraram valores muito baixos, e não foi possível estabelecer uma relação entre o grau de halitose do paciente e a sua percepção em relação ao fato.

\section{5-Considerações finais}

Devemos levar em consideração aqui que este estudo foi realizado em pacientes que apresentam bom nível de conhecimento sobre cuidados de higiene bucal e com um presumível fácil acesso ao tratamento odontológico. A fraca relação entre alguns parâmetros e a halitose não indica de forma alguma a inexistência de tal 
relação em outros grupos populacionais. Como foi dito, à medida em que a halitose se instala, a relação entre os parâmetros estudados e o hálito presumivelmente se torna mais evidente, como descrito durante a revisão da literatura por diversos autores.

Não encontramos na literatura publicações sobre o estudo da halitose em pacientes fissurados. O que se observa é que alguns autores assumem que a alteração em si pode levar ao desenvolvimento de mau-hálito ${ }^{41}$. Nossas observações levam a supor que pacientes portadores de fissura de lábio e/ou palato tratados adequadamente podem apresentar os mesmos níveis de halitose quando comparados com pacientes não portadores de fissura, desde que as condições de higiene estejam controladas. Isto reforça a importância do seguimento do paciente com fissura ao longo de seu tratamento, para manutenção de sua saúde bucal e nasal, com isso, prevenindo problemas de halitose.

O individuo com fissura de lábio e/ou palato operada possui parâmetros de halitose semelhantes ao da população geral, indicando que a correção cirúrgica e o acompanhamento por uma equipe multidisciplinar, como ocorre no HRAC, somam mais este aspecto (importante), em seu processo reabilitador, colaborando com sua integração a sociedade. 


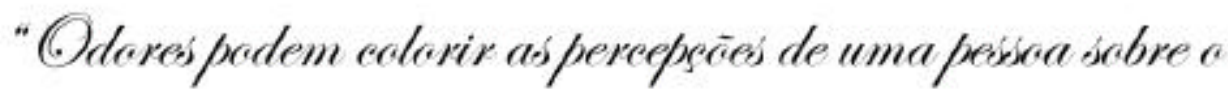
munda, tanta de forma pasitiva como negatiua. epodem influenciar a compartamento - um procesisa provauelmente resultante de associascies aprendidas".

Raurson. Tr.e.

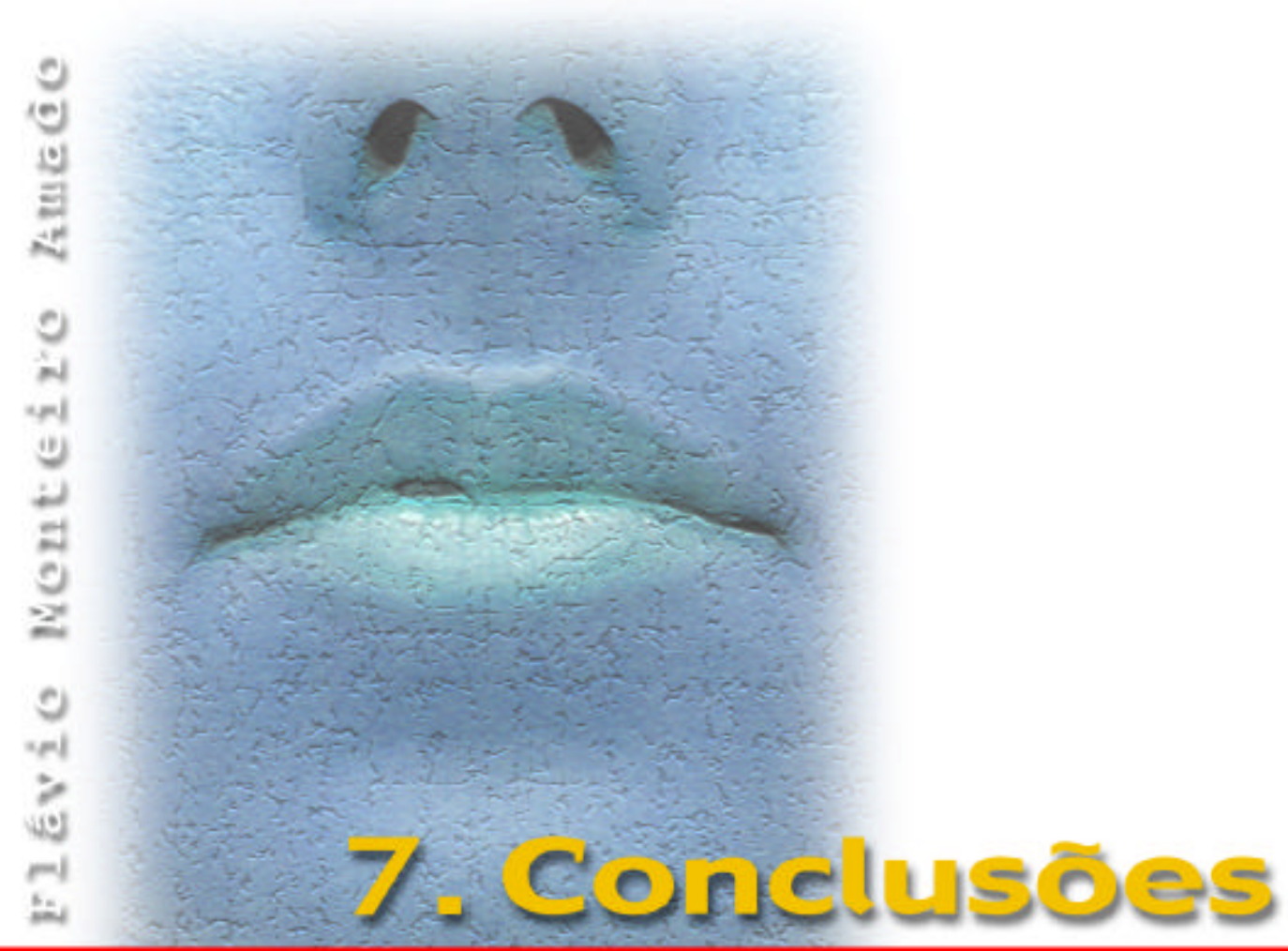




\section{CONCLUSÕES}

À luz dos resultados obtidos e da metodologia aplicada, pudemos concluir que:

1. Os níveis de halitose bucal e nasal de ambos os grupos mantiveram-se dentro de valores normais;

2. Não houve diferença estatisticamente significante para o hálito bucal entre os dois grupos;

3. O grupo 1 apresentou maiores valores de halimetria nasal do que o grupo 2;

4. Houve relação entre a presença de saburra e os níveis de CSVs, assim como entre fluxo salivar, tanto em repouso como estimulado, com os níveis de CSVs;

5. No grupo 2 pôde-se observar relação significante entre o peso da saburra e o fluxo salivar em repouso e estimulado, e a mesma relação entre o peso da saburra e o fluxo salivar estimulado foi encontrada após o agrupamento de todos os pacientes

6. Não houve relação entre os níveis de CSVs e a percepção do paciente sobre seu hálito;

7. Pacientes portadores de fissura de lábio e/ou palato reparada, tratados adequadamente, podem apresentar os mesmos níveis de halitose quando comparados com pacientes não portadores de fissura, desde que as condições de higiene estejam controladas. 


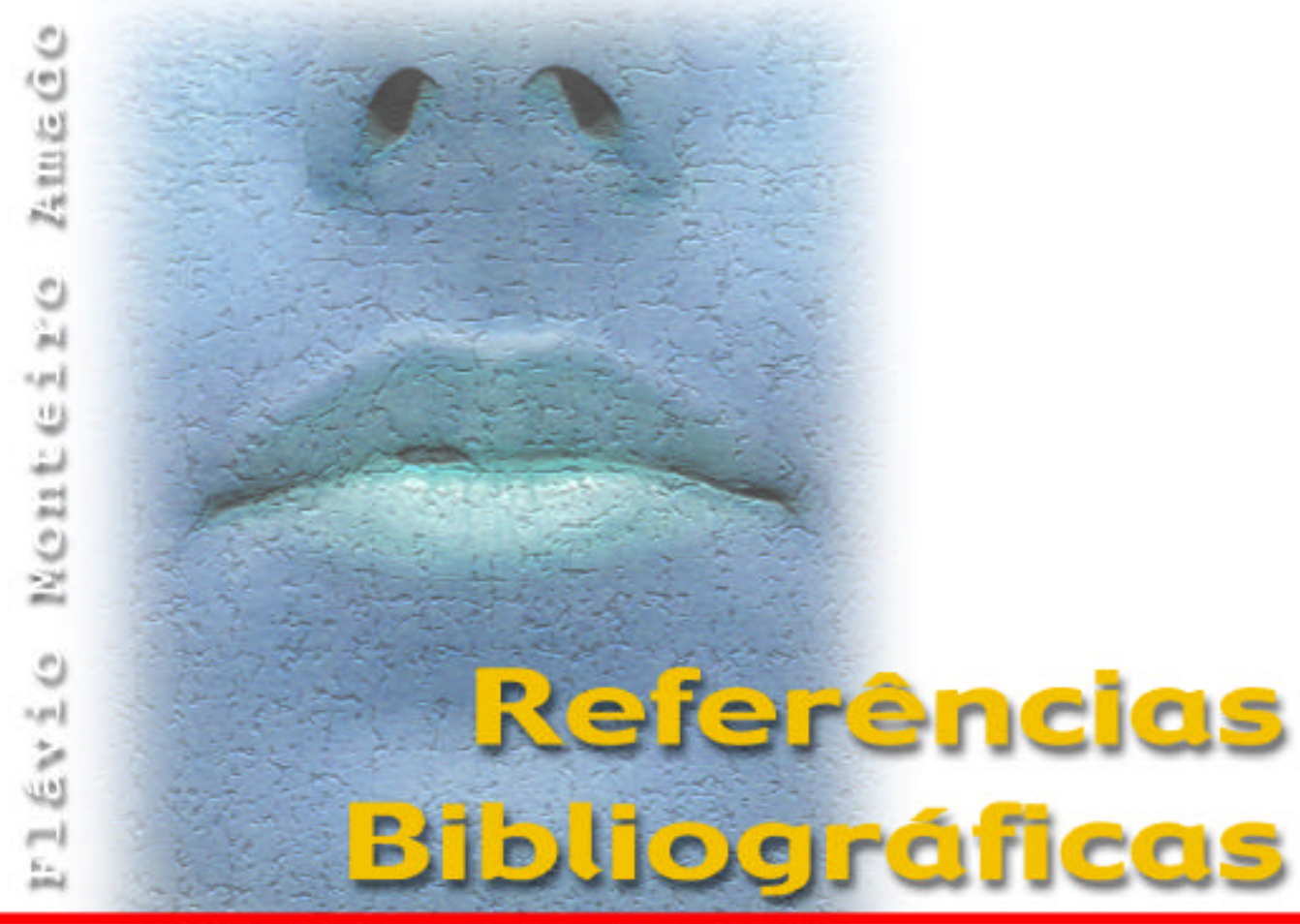




\section{REFERÊCIAS BIBLIOGRÁFICAS*}

1. AMALFITANO, J. et al. The effects of incubation length and temperature on the specificity and sensitivity of the BANA (N-benzoyl-DLarginine-naphthylamide) test. J. Periodont., v.64, n.9, p.848-52, Sept. 1993.

2. ANASTASSOV, G.E.; JOOS, U.; ZÖLLNER, B. Evaluation of the results of delayed rhinoplasty in cleft lip and palate patients. Functional and aesthetic implications that affect successful nasal repair. Brit. J. oral Maxillofac. Surg., v.36, n.6, p.416-24, Dec. 1998.

3. ASSUNÇÃO, A.G.A. Fissura lábio-palatal. Disponível na Internet. http://www.ibrbauru.com.br/fissura.asp. 10 mar. 2003.

4. ASTOR, F.C.; HANFT, K.L.; CIOCON, J.O. Xerostomia: a prevalent condition in the elderly. Ear Nose Throat J., v.78, n.7, p.476-9, July 1999.

5. AYERS, K.M.S.; COLQUHOUN, N.K. Halitosis: causes, diagnosis, and treatment. N. Z. dent. J., v.94, n.418, p.156-60, Dec. 1998.

6. AYESH, R.; MITCHELL, S.C.; SMITH, R.L. Body malodour syndromes. Lancet, v.345, n.8960, p.1308-9, May 1995.

7. BADERSTEN, A. et al. Effect of tongue brushing on formation of dental plaque. J. Periodont., v.46, n.10, p.625-7, Oct. 1975.

8. BENNETT, J.D.C. An unexpected cause of halitosis. J. R. Army Med. Corps., v.134, n.3, p.151-2, Oct. 1988.

\footnotetext{
* Normas recomendadas para uso no âmbito da Universidade de São Paulo, com base no documento "Referências Bibliográficas: exemplos", emanado do Conselho Supervisor do Sistema Integrado de Bibliotecas da USP, em reunião de 20 de setembro de 1990.
} 
9. BERG, M.; FOSDICK, L.S. Studies in periodontal disease. J. dent. Res., v.25, n.2, p.73-81, Apr. 1946.

10. BERKOWITZ, S. Cleft lip and palate: perspectives in management. San Diego, Singular, 1996.

11. BLOCK, P.L.; HOUSTON, G.D. Speech impediment and chronic halitosis due to an extensive palatal fibroma. Ann. Dent., v.46, n.1, p.20-2, Summer 1987.

12. BOGDASARIAN, R.S. Halitosis. Otolaryngol. Clin. N. Amer., v.19, n.1, p.111-7, Feb. 1986.

13. BOHN, P. Imagined halitosis: a social phobia symptom? J. Calif. dent. Ass., v.25, n.2, p.161-4, Feb. 1997.

14. BOSY, A. Oral malodor: philosophical and practical aspects. J. Canad. dent. Ass., v.63, n.3, p.196-201, Mar. 1997.

15. BOYCE, K.E.; COBB, R.A. Halitosis: a delayed complication of splenectomy. Int. J. Clin. Pract., v.52, n.8, p.590, Nov./Dec. 1998.

16. BRENING, R.H.; SULSER, G.F.; FOSDICK, L.S. The determination of halitosis by use of the osmoscope and the cryoscopic method. J. dent. Res., v.18, p.127-32, 1939.

17. BRETZ, W. et al. Minor salivary gland secretion in the elderly. Oral Surg., v.89, n.6, p.696-701, June 2000.

18. BRETZ, W.A. et al. Unstimulated salivary flow rates of young children. Oral Surg., v.91, n.5, p.541-5, May 2001. 
19. BRETZ, W.A.; LOESCHE, W.J. Characteristics of trypsin-like activity in subgingival plaque samples. J. dent. Res., v.66, n.11, p.1668-72, Nov. 1987.

20. BULL, R.H.C. Society's reactions to facial disfigurements. Dent. Update, v.17, n.5, p.202, 204-5, Jun 1990.

21. CAPELOZZA FILHO, L. et al. Conceitos vigentes na epidemiologia das fissuras lábio-palatinas. Rev. bras. Cirurg., v.77, n.4, p.223-30, ago. 1987.

22. CAPELOZZA FILHO, L. et al. Conceitos vigentes na etiologia das fissuras labiopalatinas. Rev. bras. Cirurg., v.78, n.4, p.233-40, ago. 1988.

23. CHAIM, L.A.F. Comparação entre o uso de um raspador de língua "simplificado" (RLS) e uma escova dental na higiene da língua. Rev. ABO Nac., v.9, n.4, p.242-6, ago/set. 2001.

24. CHRISTEN, A.G.; SWANSON, B.Z. Oral hygiene: a history of tongue scraping and brushing. J. Amer. dent. Ass., v.96, n.2, p.215-9, Feb. 1978.

25. CHRISTEnSEN, G.J. Why clean your tongue? J. Amer. dent. Ass., v.129, n.11, p.1605-7, Nov. 1998.

26. CLARK, G.T. Detecting and treating oral and nonoral malodors. J. Calif. dent. Ass., v.25, n.2, p.133-44, Feb. 1997.

27. COHEN, M. A new era in halitosis and periodontal treatment. Dent. Today, v.17, n.8, p.88-9, Aug. 1998. 
28. CRISPIM, A.S.S.; SAMPAIO, M.C.C. Halitose - um desafio para o estomatologista. Rev. Fac. Odont. Univ. Fed. Bahia, v.18, n.1, p.539, jan./jun. 1999.

29. CROHN, B.B.; DROSD, R. Halitosis. J. Amer. med. Ass., v.117, n.26, p.2242-5, Dec. 1941.

30. DARROW, D.H.; SIEMENS, C. Indications for tonsillectomy and adenoidectomy. Laryngoscope, v.112, n.8 (pt. 2), p.6-10, Aug. 2002.

31. DE BOEVER, E.H.; LOESCHE, W.J. Assessing the contribution of anaerobic microflora of the tongue to oral malodor. J. Amer. dent. Ass., v.126, n.10, p.1384-93, Oct. 1995.

32. DELANGHE, G. et al. Multidisciplinary breath-odour clinic. Lancet, v.350, n.9072, p.187, July 1997.

33. DIOS, P.D.; POSSE, J.L.; CARMONA, I.T. Schizophrenia and halitosis. Oral Surg., v.89, n.6, p.661, June 2000.

34. DOMINIC, P.L. Halitosis: an etiologic classification, a treatment approach, and prevention. Oral Surg., v.54, n.5, p.521-6, Nov. 1982.

35. DURHAM, T.; MALLOY, T.; HODGES, E.D. Halitosis: knowing when 'bad breath' signls systemic disease. Geriatrics, v.48, n.8, p.55-9, Aug. 1993.

36. ELI, I. et al Self-perception of breath odor. J. Amer. dent. Ass., v.132, n.5, p.621-6, May 2001.

37. EPSTEIN, J.B. The role of saliva in oral health and the causes and effects of xerostomia. J. Canad. dent. Ass., v.58, n.3, p.217-21, Mar. 1992. 
38. ESTRELA, C.; PIMENTA, F.C.; ESTRELA, C.R.A. Testes microbiológicos aplicados à pesquisa odontológica. In: ESTRELA, C. Metodologia científica: ensino e pesquisa em odontologia. São Paulo, Artes Médicas, 2001. p.211.

39. FEITOSA, A.C.R.; AMALFITANO, J.; LOESCHE, W.J. The effect of incubation temperature on the specificity of the BANA (N-benzoylDL-arginine-naphthylamide) test. Oral Microbiol. Immunol., v.8, n.1, p.57-61, Feb. 1993.

40. FIGUEIREDO, L.C. et al The relationship of oral malodor in patients with or without periodontal disease. J. Periodont., v.73, n.11, p.1338-42, Nov. 2002.

41. FINKELSTEIN, Y. Halitosis in patients with craniofacial anomalies. In: ROSENBERG, M. Bad breath: research perspectives. Israel, Ramot publishing - Tel Aviv University, 1995. p.189-200.

42. FURNE, J. et al. Comparison of volatile sulfur compound concentrations measured with a sulfide detector vs. gas chromatography. J. dent. Res., v.81, n.2, p.140-3, Feb. 2002.

43. GAGGL, A. et al. Periodontal disease in patients with cleft palate and patients with unilateral and bilateral clefts of lip, palate, and alveolus. J. Periodont., v.70, n.2, p.171-8, Feb. 1999.

44. GAINES nutrition: online health food store. http://www.gaines.com/store/BreathAsure/FHP29400info.html.

Disponível na Internet, v.18, mar, 2003. 
45. GILMORE, E.L.; BHASKAR, S.N. Effect of tongue brushing on bacteria and plaque formed in vitro. J. Periodont., v.43, n.7, p.418-22, July 1972.

46. GOLDBERG, S. et al. Cadaverine as a putative component of oral malodor. J. dent. Res., v.73, n.6, p.1168-72, June 1994.

47. GOLDBERG, S. et al. Isolation of enterobacteriaceae from the mouth and potential association with malodor. J. dent. Res., v.76, n.11, p.1770-5, Nov. 1997.

48. HAM, D.S.; CHUN, Y.H.; HONG, J.P. A study of personality profile of halitosis patients by simptom checklist-90-revision(SCL-90-R). J. dent. Res., v.78, n.5, p.1148, May 1999.

49. HAMLAR, D.D. et al. Determination of the efficacy of topical oral pilocarpine for postrradiation xerostomia in patients with head and neck carcinoma. Laryngoscope, v.106, n.9, p.972-6, Aug. 1996.

50. HERLOFSON, B.B.; BARKVOLL, P. Desquamative effect of sodium lauryl sulfate on oral mucosa. Acta odont. scand., v.51, n.1, p.39-43, Feb. 1993.

51. HERLOFSON, B.B.; BARKVOLL, P. Oral mucosal desquamation of pre- and post-menopausal women. A comparison of response to sodium lauryl sulfate in toothpastes. J. clin. Periodont., v.23, n.6, p.567-71, June 1996.

52. HERLOFSON, B.B.; BARKVOLL, P. Oral mucosal desquamation caused by two toothpaste detergents in an experimental model. Europ. J. Oral Sci., v.104, n.1, p.21-6, Feb. 1996. 
53. HINE, M.K. Halitosis. J. Amer. dent. Ass., v.55, n.1, p.37-46, July 1957.

54. HOFEN, J.S. Working with cleft palate. Southampton, Winslow Press, 1996.

55. IWAKURA, M. et al. Clinical characteristics of halitosis: differences in two patient groups with primary and secondary complaints of halitosis. J. dent. Res., v.73, n.9, p.1568-74, Sept. 1994.

56. IWU, C.O.; AKPATA, O. Delusional halitosis. Review of the literature and analysis of 32 cases. Brit. dent. J., v.168, n.7, p.294-6, Apr. 1990.

57. JACOBSON, S.E.; CRAWFORD, J.J.; MCFALL, W.R. Oral physiotherapy of the tongue and palate: relationship to plaque control. J. Amer. dent. Ass., v.87, n.1, p.134-9, July 1973.

58. KÄLÉN, K. Maternal smoking and orofacial clefts. Cleft palate craniofac. J., v.34, n.1, p.11-16, Jan. 1997.

59. KLEINBERG, I.; WESTBAY, G. Salivary and metabolic factors involved in oral malodor formation. J. Periodont., v.63, n.9, p.76875, Sept. 1992.

60. KLOKKEVOLD, P.R. Oral malodor: a periodontal perspective. J. Calif. dent. Ass., v.25, n.2, p.153-9, Feb. 1997.

61. KOZLOVSKY, A. et al. Correlation between the BANA test and oral malodor parameters. J. dent. Res., v.73, n.5, p.1036-42, May 1994. 
62. LARSSON, B.T. A gas chromatographic study of the effect of ascorbic acid oxidation on the formation of volatiles in saliva samples. Scand. J. dent. Res., v.81, n.1, p.22-6, 1973.

63. LAUREnDET, H. et al Snoring and halitosis in a dog. Aust. Vet. J., v.76, n.4, p.245, 250-1, Apr. 1998.

64. LOCKHART, P.B. et al. Pilot study of controlled-release pilocarpine in normal subjects. Oral Surg., v.82, n.5, p.517-24, Nov. 1996.

65. LOESCHE, W.J.; KAZOR, C.E.; TAYLOR, G.W. The optimization of the BANA test as a screening instrument for gingivitis among subjects seeking dental treatment. J. clin. Periodont., v.24, n.10, p.718-26, Oct. 1997.

66. LOESCHE, W.J. et al. Development of a diagnostic test for anaerobic periodontal infections based on plaque hydrolysis of benzoyl-DLarginine-naphthylamide. J. clin. Microbiol., v.28, n.7, p.1551-9, July. 1990.

67. LOESCHE, W.J. et al. Comparison of the benzoyl-DL-argininenaphthylammide (BANA) test, DNA probes, and immunoological reagentrs for ability to detect anaerobic periodontal infections due to Porphyromonas gingivalis, Treponema denticola, and Bacteróides forsyhtus. J. clin. Microbiol., v.30, n.2, p.427-33, Feb. 1992.

68. MARCU, A. Let's talk about bad breath. N. Y. J. Dent., v.49, n.7, p.2313, Aug./Sept. 1979.

69. MCNAMARA, T.F. et al. The role of microorganisms in the production of oral malodor. Oral Surg., v.34, n.1, p.41-8, July 1972. 
70. MENON, M.V.; COYKENDALL, A.L. Effect of tongue scraping. J. dent. Res., v.73, n.9, p.1492, Sept. 1994.

71. MESSADI, D.V. Oral and nonoral sources of halitosis. J. Calif. dent. Ass., v.25, n.2, p.127-31, Feb. 1997.

72. MORITA, M.; MUSINSKY, D.L.; WANG, H. L. Assessment of newly developed tongue sulfide probe for detecting oral malodor. J. clin. Periodont., v.28, n.5, p.494-6, May 2001.

73. MORITA, M.; WANG, H.L. Relationship between sulcular sulfide level and oral malodor in subjects with periodontal disease. J. Periodont., v.72, n.1, p.79-84, Jan. 2001.

74. NACHNANI, S.; CLARK, G.T. Halitosis: a breath of fresh air. Clin. Infect. Dis., v.25, p.S218, Sept. 1997. Supplement 2.

75. NIEDERMEIER, W. et al. Radiation-induced hyposalivation and its treatment with oral pilocarpine. Oral Surg., v.86, n.5, p.541-9, Nov. 1998.

76. OHO, T. et al. Characteristics of patients complaining of halitosis and the usefulness of gas chromatography for diagnosing halitosis. Oral Surg., v.91, n.5, p.531-4, May 2001.

77. OXTOBY, A.; FIELD, E.A. Delusional symptoms in dental patients: a report of four cases. Brit. dent. J., v.176, n.4, p.140-3, Feb. 1994.

78. RATCLIFF, P.A.; JOHNSON, P.W. The relationship between oral malodor, gingivitis, and periodontitis. A review. J. Periodont., v.70, n.5, p.485-9, May 1999. 
79. RAWLINGS, J.M.; CULHAM, N. Halitosis in dogs and the effect of periodontal terapy. J. Nutr., v.128, n.12, p.2715S-6S, Dec. 1998. Supplement.

80. RAWLINGS, J.M.; CULHAM, N. Studies of oral malodor in the dog. J. Vet. Dent., v.15, n.4, p.169-73, Dec. 1998.

81. REPlogle, W.H.; BEEBE, D.K. Halitosis. Am. Fam. Physician., v.53, n.4, p.1215-8, 1223, Mar. 1996.

82. RICHTER, J.L. Diagnosis and treatment of halitosis. Comp. Continuing Educ. Dent., v.17, n.4, p.370-2, 374-6, Apr. 1996.

83. RICHTER, V.J.; TONZETICH, J. The application of instrumental technique for the evaluation of odoriferous volatiles from saliva and beath. Arch. oral Biol., v.9, n.1, p.47-53, Jan./Feb. 1964.

84. ROSENBERG, M. Clinical assessment of bad breath: current concepts. J. Amer. dent. Ass., v.127, n.4, p.475-82, Apr. 1996.

85. ROSENBERG, M.; MCCULLOCH, C.A.G. Measurement of oral malodor: current methods and future prospects. J. Periodont., v.63, n.9, p.776-82, Sept. 1992.

86. ROSENBERG, M. et al. Reproducibility and sensitivity of oral malodor measurements with a portable sulphide monitor. J. dent. Res., v.70, n.11, p.1436-40, Nov. 1991.

87. ROSENBERG, M. et al. Self-estimation of oral malodor. J. dent. Res., v.74, n.9, p.1577-83, Sept. 1995. 
88. RUBRIGHT, W.C. et al. Oral slough caused by dentifrice detergents and aggravated by drugs with antisialic activity. J. Amer. dent. Ass., v.97, n.2, p.215-20, Aug. 1978.

89. SCULLY, C.; PORTER, S. Orofacial disease: update for the dental clinical team: 10. Halitosis and disturbaces of taste, orofacial movement or sensation. Dent. Update., v.26, n.10, p.464-8, Dec. 1999.

90. SCULLY, C. et al. Breath odor: etiopatogenesis, assessment and management. Europ. J. Oral. Sci., v.105, n.4, p.287-93, Aug. 1997.

91. SEEMANN, R. et al. Effectiveness of tongue cleaning on oral levels of volatile sulfur compounds. J. Amer. dent. Ass., v.132, n.9, p.1263-7, Sept. 2001.

92. SHELTS, R.L. Evaluation of an oral antibacterial agent in dogs and cats.

J. Amer.vet. med. Ass., v.140, n.15, p.801-2, Apr. 1962.

93. SHIMURA, M. et al. A new monitor with a zin-oxide thin film semiconductor sensor for the measurement of volatile sulfur compounds in mouth air. J. Periodont., v.67, n.4, p.396-402, Apr. 1996.

94. SHPRINTZEN, R.J.; BARDACH, J. Cleft palate speech management. St. Louis, Mosby, 1995.

95. SILVA FILHO, O.G. et al. Clasificação das fissuras lábio-palatais: breve histórico, considerações clíncas e sugestão de modificação. Rev. bras. Cirurg., v.82, n.2, p.59-64, mar/abr. 1992. 
96. SLAVKIN, H.C.; BAUM, B.J. Relationship of dental and oral pathology to systemic illness. J. Amer. med. Ass., v.284, n.10, p.1215-17, Sept 2000 .

97. SOHN, W.Y.; CHUN, Y.H.; HONG, J.P. A study of relationship between halitosis and salivary gland function. J. dent. Res., v.78, n.5, p.1148, May 1999.

98. SPRINGFIELD, J. et al. Spontaneous fluctuations in the concentrations of oral sulfur-containing gases. J. dent. Res., v.80, n.5, p.1441-4, May 2001.

99. SREEBNY, L.M. Recognition and treatment of salivary induced conditions. Int. dent. J., v.39, n.3, p.197-204, Sept. 1989.

100. SREEBNY, L.M.; VALDINI, A.; YU, A. Xerostomia. Part II: relationship to nonoral symptoms, drugs, and diseases. Oral Surg., v.68, n.4 (pt. 1), p.419-427, Oct. 1989.

101. STAlLARD, H. Residual food odors of the mouth. J. Amer. dent. Ass., v.14, n.9, p.1689-93, Sept. 1927.

102. STERER, N.; BAR-NESS GREENSTEIN, R.; ROSENBERG, M. BETA-galactosidase activity in saliva is associated with oral malodor. J. dent. Res., v.81, n.3, p.182-5, Mar. 2002.

103. SUAREZ, F.L. et al. Morning breath odor: influence of treatments on sulfur gases. J. dent. Res., v.79, n.10, p.1773-7, Oct. 2000.

104. SULSER, G.F.; BRENING, R.H.; FOSDICK, L.S. Some conditions that effect odor concentration of breath. J. dent. Res., v.18, p.355-9, 1939. 
105. SULSER, G.E.; LESNEY, T.A.; FOSDICK, L.S. The reduction of breath and mouth odors by means of brushing the teeth. J. dent. Res., v.19, p.173-7, 1940.

106. SYED, S.A. et al. Diagnostic potential of chromogenic substrates for rapid detection of bacterial enzymatic activity in health and disease associated periodontal plaques. J. Periodont. Res., v.19, n.6, p.618$21,1984$.

107. SYRJÄNEN, J. Vascular diseases and oral infections. J. clin. Periodont., v.17, n.7(pt 2), p.497-500, Aug. 1990.

108. TARZIA, O. Halitose. Rio de Janeiro, EPUC, 1991.

109. TARZIA, O. Apostila de bioquímica da saliva. Bauru, Universidade de São Paulo, 1992.

110. TARZIA, O. Tratamento odontológico da halitose. In: CARDOSO, J.S.C. Odontopediatria: prevenção. São Paulo, Artes Médicas, 2002. p.317-29.

111. TAYLOR, S.E.; AL-HASHIMI, I. Pilocarpine, an old drug; a new formulation. Tex. dent. J., v.113, n.10, p.9-13, Oct. 1996.

112. TESSIER, J.F.; KULKARNI, G.V. Bad breath: etiology, diagnosis and treatment. Oral Health., v.81, n.10, p.19-22, 24, Oct. 1991.

113. TIOMNY, E. et al. Halitosis and helicobacter pylory. A possible link? J. clin. Grastoenterol., v.15, n.3, p.236-7, Oct. 1992. 
114. TONZETICH, J. Production and origin of oral malodor: a review of mechanisms and methods of analysis. J. Periodont., v.48, n.1, p.1320, Jan. 1977.

115. TONZETICH, J. Oral malodour: an indicatior of health status and oral cleanliness. Int. dent. J., v.28, n.5, p.309-19, Sept. 1978.

116. TONZETICH, J.; LO, K.K.C. Uptake of H2S by salivary proteins and cellular elements. J. dent. Res., v.55, p.B324, Apr. 1976. Special issue $\mathrm{B}$.

117. TONZETICH, J.; RICHTER, V.J. Evaluation of volatile odoriferous components of saliva. Arch. oral Biol., v.9, n.1, p.39-45, Jan./Feb. 1964.

118. TORRES, R.; VIANNA, R. Comparative study between two different groups regarding halitosis. J. dent. Res., v.78, n.5, p.985, May 1999.

119. TURKSON, S.N.A. Psychiatric patients presenting with primarily somatic symptoms: report of two cases. East Afr. Med. J., v.75, n.9, p.556-7, Sept. 1998.

120. TYDD, T.F.; DYER, N.H. Pyloric stenosis presenting with halitosis.

Brit. med. J., v.3, n.5926, p.321, Aug. 1974.

121. ULIANA, R.M.B.; BRIQUES, W.; CONTI, R. Microbiota oral e suas repercussões no hálito. In: CARDOSO, R.J.A.;GONÇALVES, E.A.N. Odontopediatria: prevenção. São Paulo, Artes Médicas, 2002. p.297-308. 
122. USING gas chromatography to evaluate bad breath. Disponível na Internet. http://www.animated-

teeth.com/bad breath/t1 halitosis.htm, 18 mar, 2003.

123. VALDEZ, I.H. et al. Use of pilocarpine during head and neck radiation therapy to reduce xerostomia and salivary dysfunction. Cancer., v.71, n.5, p.1848-51, Mar. 1993.

124. VAN STEENBERGHE, D. Breath malodor. Curr. Opinion Periodontol., v.4, p.137-43, 1997.

125. VAN STEENBERGHE, D. et al. Effect od different mouthrinses on morning breath. J. Periodont., v.72, n.9, p.1183-91, Sept. 2001.

126. WALER, S.M. On the transformation of sulfur-containing amino acids and peptides to volatile sulfur compounds (VSC) in the human mouth. Europ. J. Oral Sci., v.105, n.5(pt 2), p.534-7, Oct. 1997.

127. WARREN, D.W.; HAIRFIELD, M.; DALSTON, E.T. Nasal airway impairment: the oral response in cleft palate patients. Amer. J. Orthodont. Dentofac. Orthop., v.99, n.4, p.346-53, Apr. 1991.

128. WILLIS, C.L. et al. Negative correlation between oral malodour and numbers and activities of sulphate-reducing bacteria in the human mouth. Arch. oral Biol., v.44, n.8, p.665-70, Aug. 1999.

129. YAEGAKI, K.; SANADA, K. Volatile sulfur compounds in mouth air from clinically healthy subjects and patients with periodontal disease. J. Periodont. Res., v.27, n.4(pt1), p.233-8, July. 1992.

130. YOUNG, K.; OXTOBY, A.; FIELD, E.A. Halitosis: a review. Dent. Update., v.20, n.2, p.57-9, 61, Mar. 1993. 


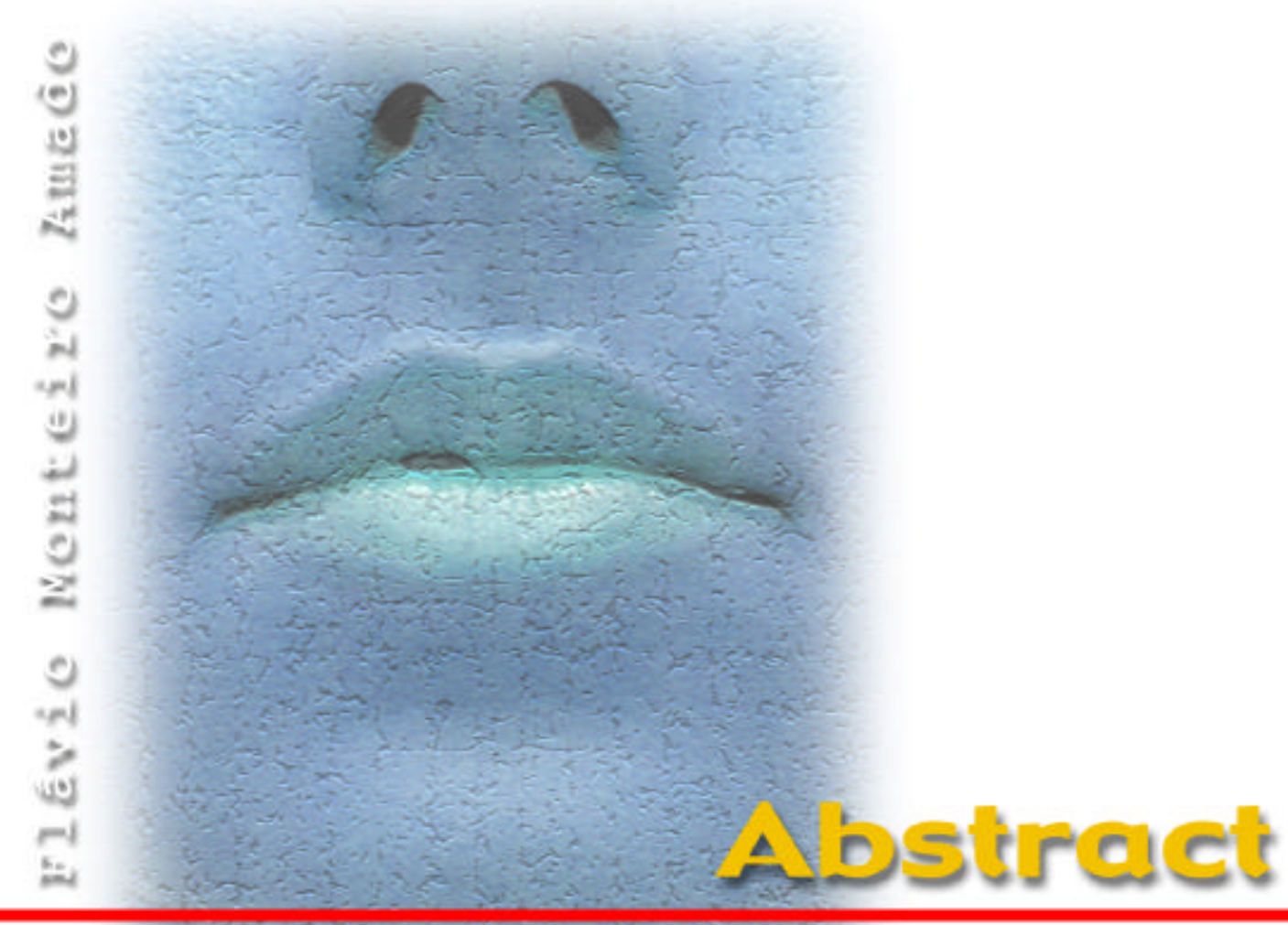




\section{Evaluation of oral and nasal odor in patients with and without cleft lip and/or palate}

The aim of this study was to investigate the relationship between the parameters of halitosis in patients with cleft lip and/or palate and post-graduation students of the Bauru Dental School (FOB) - University of Sao Paulo, taking into account the presence of tongue coating, classified according to its dry weight, salivary flow rate, $\mathrm{BANA}^{\mathrm{TM}}$ test and Halimeter ${ }^{\mathrm{TM}}$ oral and nasal measurements, and compare the results of both groups. A total of 40 subjects were examined, which were divided into two groups. Group 1 was constituted by the post-graduation students of FOB, with no complains of bad breath, and Group 2 comprised individuals presenting with repaired cleft lip and/or palate living in the city of Bauru. The concentration of Volatile Sulfur Compounds (VSC) was assessed by means of a portable sulfide monitor $\left(\right.$ Halimeter $^{\mathrm{TM}}$ ) and the values were correlated to the resting and stimulated salivary flow rate and to the $\mathrm{BANA}^{\mathrm{TM}}$ test with material collected from the tongue coating and its dry weight. Results were analyzed by means of the dependent and independent $t$ test for the scalar quantitative variables halitosis, salivary flow rate and weight of the tongue coating. The results demonstrated a relationship between the presence of tongue coating and the VSC levels, as well as between both resting and stimulated salivary flow rate and the VSC levels. Group 2 also revealed a significant correlation between the weight of the tongue coating and the resting and stimulated salivary flow rate. There were no significant differences between groups as regards to the Halimeter ${ }^{\mathrm{TM}}$ oral measurement, yet Group 1 presented higher values for the Halimeter ${ }^{\mathrm{TM}}$ nasal measurements than Group 2. No relationship could be found between the VSC levels and the patient's perception about his or her own breath. Patients with operated cleft lip and/or palate did not demonstrate any significant differences on the study parameters when compared to subjects without cleft. 


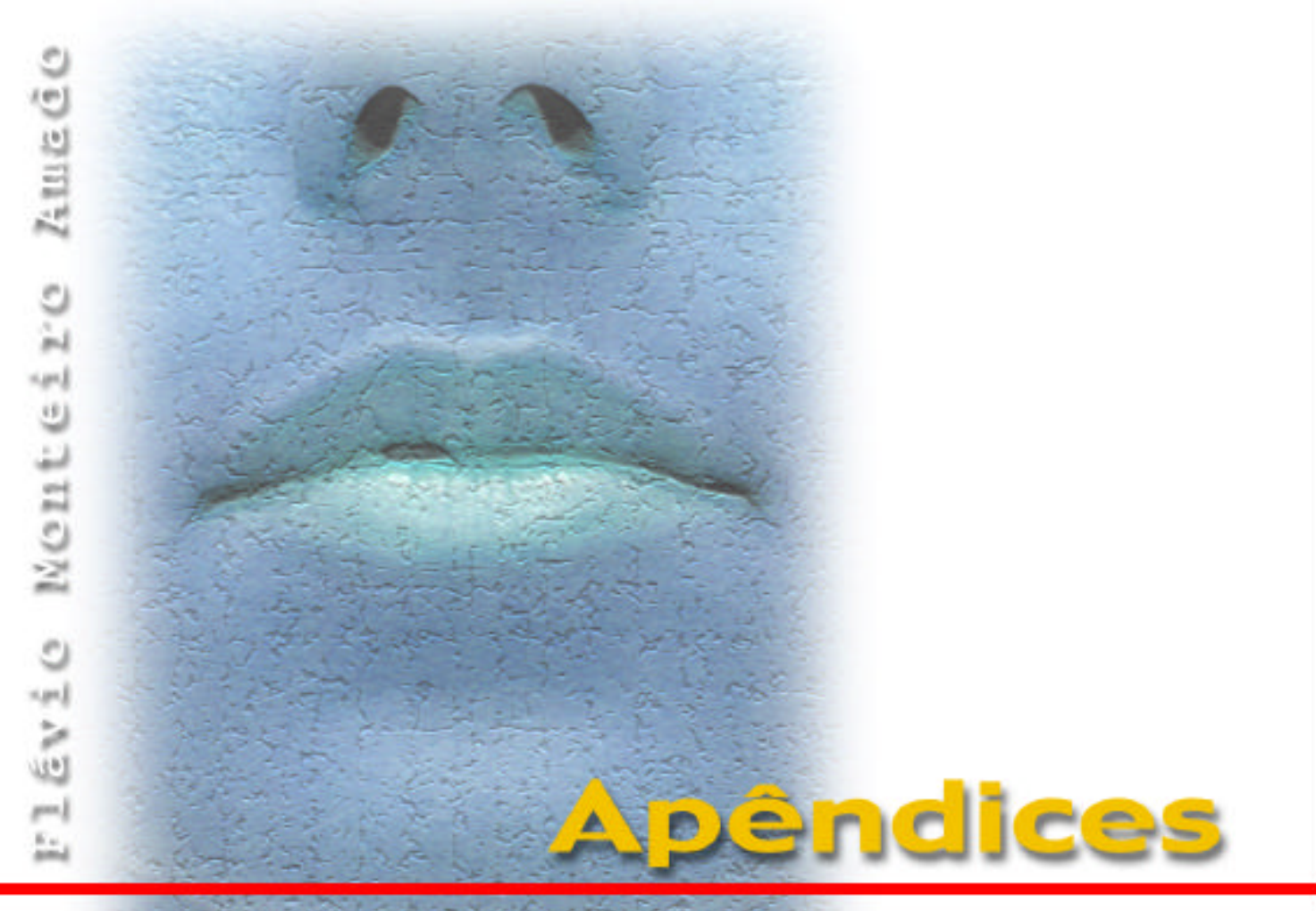




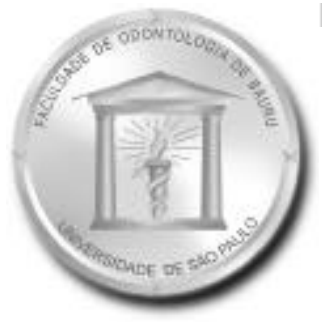

\section{APÊNDICE 1}

UNIVERSIDADE DE SÃO PAULO

FACULDADE DE ODONTOLOGIA DE BAURU

Al. Dr. Octávio Pinheiro Brisolla, 9-75 - Bauru-SP - CEP 17012-901 - C.P.

PABX (0XX14)235-8000 - FAX (0XX14)223-4679

\section{DEPARTAMENTO DE ESTOMATOLOGIA}

\section{CARTA DE INFORMAÇAO AO PACIENTE}

Por este instrumento que atende às exigências do COMITÊ DE ÉTICA EM PESQUISA da Faculdade de Odontologia de Bauru (FOB) - USP, venho informar a portador(a) da cédula de identidade $\mathrm{n}^{\circ}$ sobre os procedimentos aos quais será submetido

durante o transcorrer desta pesquisa.

A pesquisa da qual você foi solicitado(a) a participar não envolve a requisição de documentação realizada por centros especializados, não implicando assim em quaisquer gastos pessoais de sua parte. Você responderá a um questionário e será submetido a um exame bucal, que terá a finalidade de descobrir a presença de algum fator que possa provocar alteração no hálito. Na detecção de algum dos fatores causadores da halitose você será tratado ou encaminhado(a) para tal.

Sua contribuição será colaborar comparecendo ao exame odontológico solicitado pelo seu dentista e cumprindo suas recomendações, evitando assim qualquer problema que possa comprometer os resultados da pesquisa à qual você estará participando. Deve-se esclarecer que todas as fotografias, históricos de antecedentes familiares, resultados de exames clínicos e de laboratório e quaisquer outras informações concernentes ao seu atendimento poderão ser utilizados por esta Faculdade (FOB), para fins de pesquisa, ensino e divulgação em jornais e/ou revistas nacionais e internacionais. Estando ciente e tendo sido informado de todos os procedimentos a serem realizados, o senhor (paciente) autoriza a prosseguimento das etapas do tratamento, segundo o protocolo mencionado e descrito anteriormente.

Assinatura do paciente ou responsável 


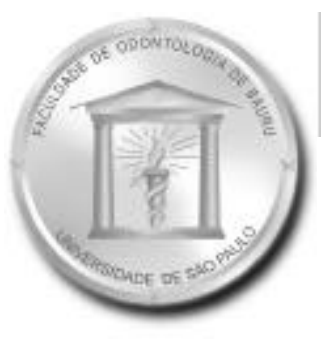

\author{
APÊNDICE 2 \\ UNIVERSIDADE DE SÃO PAULO \\ FACULDADE DE ODONTOLOGIA DE BAURU \\ Al. Dr. Octávio Pinheiro Brisolla, 9-75 - Bauru-SP - CEP 17012-901 - C.P. \\ PABX (0XX14)235-8000 - FAX (0XX14)223-4679
}

DEPARTAMENTO DE ESTOMATOLOGIA

\title{
TERMO DE CONSENTIMENTO LIVRE E ESCLARECIDO
}

Pelo presente instrumento que atende às exigências legais, o(a) senhor(a) portador(a) da cédula de identidade $\mathrm{n}^{0}$ , após leitura minuciosa da CARTA DE INFORMAÇÃO

AO PACIENTE, devidamente explicada pelo(s) profissional(is) em seus mínimos detalhes, ciente dos serviços e procedimentos aos quais será submetido, não restando quaisquer dúvidas a respeito do lido e do explicado, firma seu CONSENTIMENTO LIVRE E ESCLARECIDO em concordância em participar da pesquisa proposta no que lhe é cabível, conforme a CARTA DE INFORMAÇÃO AO PACIENTE.

Fica claro que o paciente ou seu representante legal pode a qualquer momento retirar seu CONSENTIMENTO LIVRE E ESCLARECIDO e deixar de participar do estudo alvo da pesquisa e ciente que todo o trabalho realizado tornase informação confidencial guardada por força do sigilo profissional (Art.9º do Código de Ética Odontológica).

Por estarem entendidos e conformados, assinam o presente termo.

Bauru/SP, de 2002 


\section{APÊNDICE 3}

\section{UNIVERSIDADE DE SÃO PAULO}

FACULDADE DE ODONTOLOGIA DE BAURU

Al. Dr. Octávio Pinheiro Brisolla, 9-75 - Bauru-SP - CEP 17012-901 - C.P. PABX (0XX14)235-8000 - FAX (0XX14)223-4679

DEPARTAMENTO DE ESTOMATOLOGIA

\section{INSTRUÇÕES PRÉVIAS À CONSULTA}

1. Evitar, 24 horas antes da consulta, comida muito condimentada.

2. Evitar, 3 horas antes da consulta:
a. Escovar os dentes;
b. Usar fio dental;
c. Usar enxaguatório bucal;
d. Usar pastilha, chiclete;
e. Bebidas alcoólicas;
f. Fumar.

3. No momento da consulta, não estar usando perfume, colônia, loção pós-barba. 


\section{APÊNDICE 4}

UNIVERSIDADE DE SÃO PAULO

FACULDADE DE ODONTOLOGIA DE BAURU

Al. Dr. Octávio Pinheiro Brisolla, 9-75 - Bauru-SP - CEP 17012-901 - C.P.

PABX (0XX14)235-8000 - FAX (0XX14)223-4679

DEPARTAMENTO DE ESTOMATOLOGIA

Protocolo de coleta de dados e avaliacão dos parâmetros de halitose

FICHA:

Nome:

Data e local do nascimento:

idade:

sexo:

cor:

Profissão:

Estado civil:

Endereço:

Bairro:

Cidade:

Estado:

Telefone:

Tipo de fissura:

Fez cirurgia reparadora?

\section{EXAME CLÍNICO}

Higiene: BOA RUIM

Escovação: Uso de fio de ntal:

Há sangramento com o uso do fio dental?

Usa bochechos ou "spray"? Qual?

Cáries:

Impacção alimentar: Uso de prótese:

Cálculo: Sangramento gengival:

Gengivite: Feridas cirúrgicas:

Comunicação buco-sinusal ou buco-nasal:

\section{LÍNGUA}

Língua geográfica: SIM

NÃO Língua fissurada: SIM NÃO

Coloração: Edema:

SIM

NÃO

Irritação: SIM

NÃO Dor: SIM NÃO

Ardência: SIM

NÃO Alteração/perda do paladar: SIM NÃO

Saburra/localização:

\section{MUCOSAS}

Mordida de bochecha:

$\begin{array}{ll}\text { SIM } & \text { NÃO } \\ \text { SIM } & \text { NÃO } \\ \text { SIM } & \text { NÃOO }\end{array}$

Mordida de comissura labial:

Uso de aparelho ortodôntico:

SIM NÃO

Uso de prótese: SIM

NÃO Respirador Bucal: SIM NÃO 


\section{APÊNDICE 5}

\section{UNIVERSIDADE DE SÃO PAULO}

FACULDADE DE ODONTOLO GIA DE BAURU

Al. Dr. Octávio Pinheiro Brisolla, 9-75 - Bauru-SP - CEP 17012-901 - C.P.

PABX (0XX14)235-8000 - FAX (0XX14)223-4679

\section{DEPARTAMENTO DE ESTOMATOLOGIA \\ FICHA:}

\section{XEROSTOMIA}

Boca seca: SIM

Olhos secos: SIM

NÃo Ardência na boca: SIM NÃO

Listar medicamentos

NÃO Uso de algum medicamento: SIM NÃO

Ingestão de água:

\section{OTORRINOLARINGOLOGIA}

Sinusite/Rinite/Amigdalite/Adenóides

SAÚDE GERAL (há algum problema?)

Digestivo/Intestinal/Hepático/Pulmonar/Renal/Diabe tes/Hipertensão/Reumatismo Problema ginecológico/Alergia/Doença auto-imune.

\section{HÁBITOS}

Fumo/Bebidas/Drogas

Algum problema que não foi perguntado?

AUTO-PERCEPÇÃO DO HÁLITO

HOJE

$\begin{array}{lllllllllll}0 & 1 & 2 & 3 & 4 & 5 & 6 & 7 & 8 & 9 & 10\end{array}$

EM UM DIA COMUM

$\begin{array}{lllllllllll}\mathbf{0} & 1 & 2 & 3 & 4 & 5 & 6 & 7 & 8 & 9 & 10\end{array}$




\section{APÊNDICE 6}

\section{UNIVERSIDADE DE SÃO PAULO}

FACULDADE DE ODONTOLOGIA DE BAURU

Al. Dr. Octávio Pinheiro Brisolla, 9-75 - Bauru-SP - CEP 17012-901 - C.P.

PABX (0XX14)235-8000 - FAX (0XX14)223-4679

\section{DEPARTAMENTO DE ESTOMATOLOGIA}

FICHA:

\section{EXAMES OBJETIVOS PARA O HÁLITO}

\section{HALIMETRIA}

boca:

boca:

boca:

boca (soltando o ar):

narina direita:

narina esquerda:

RESULTADO DO TESTE DE BANA-

\section{PESO DA SABURRA}

\section{HALIMETRIA}

boca:

boca:

boca:

\section{SIALOMETRIA}

Não estimulada:

Estimulada: 
APÊNDICE 7

\section{DADOS DOS PACIENTES SEM FISSURA}

\begin{tabular}{|c|c|c|c|c|c|c|c|c|c|}
\hline $\mathrm{H} 1$ & $\mathrm{H} 2$ & SAB & BANA & SREP & SEST & AUTOP & $\mathrm{H} 3$ & $\mathrm{HN}$ & SEXO \\
\hline 70 & 67 & 0,007 & 1 & 0,12 & 1 & 7 & 70 & 60 & $f$ \\
\hline 48 & 39 & 0,0095 & 0 & 0,2 & 1 & 2 & 36 & 60 & $f$ \\
\hline 116 & 115 & 0,0108 & 1 & 0,4 & 3,3 & 3 & 59 & 52 & $\mathrm{~m}$ \\
\hline 48 & 41 & 0,0257 & 0 & 0,16 & 2 & 0 & 48 & 60 & $\mathrm{~m}$ \\
\hline 61 & 122 & 0,0066 & 1 & 0 & 0,5 & 8 & 68 & 53 & $\mathrm{~m}$ \\
\hline 89 & 62 & 0,0506 & 1 & 0,04 & 1,04 & 3 & 63 & 98 & $\mathrm{~m}$ \\
\hline 61 & 58 & 0,0045 & 1 & 0,16 & 1,52 & 6 & 94 & 71 & $\mathrm{~m}$ \\
\hline 54 & 56 & 0,0068 & 1 & 0,36 & 1,32 & 3 & 45 & 60 & $f$ \\
\hline 46 & 42 & 0,017 & 0 & 0,16 & 0,68 & 5 & 52 & 39 & $\mathrm{~m}$ \\
\hline 205 & 152 & 0,0165 & 0 & 0,2 & 0,48 & 3 & 49 & 42 & $\mathrm{~m}$ \\
\hline 51 & 52 & 0,012 & 1 & 0,04 & 1,24 & 3 & 51 & 97 & $f$ \\
\hline 66 & 47 & 0,006 & 0 & 0,12 & 2 & 1 & 50 & 97 & $\mathrm{~m}$ \\
\hline 140 & 69 & 0,0094 & 1 & 0,08 & 0,52 & 5 & 63 & 65 & $\mathrm{~m}$ \\
\hline 305 & 107 & 0,007 & 1 & 0,2 & 0,8 & 2 & 142 & 47 & $f$ \\
\hline 40 & 50 & 0,0104 & 0 & 0,36 & 0,68 & 4 & 32 & 38 & $f$ \\
\hline 50 & 54 & 0,0057 & 0 & 0,04 & 0,68 & 3 & 35 & 100 & $\mathrm{~m}$ \\
\hline 34 & 25 & 0,016 & 0 & 0,2 & 0,8 & 7 & 34 & 66 & $\mathrm{~m}$ \\
\hline 38 & 31 & 0 & 0 & 0,2 & 2,08 & 5 & 36 & 56 & f \\
\hline 241 & 155 & 0,0502 & 0 & 0,16 & 1,16 & 5 & 53 & 48 & $\mathrm{~m}$ \\
\hline 65 & 75 & 0,0135 & 0 & 0,08 & 0,44 & 5 & 68 & 57 & $f$ \\
\hline 40 & 40 & 0,0069 & 0 & 0,48 & 1,32 & 8 & 34 & 36 & $\mathrm{~m}$ \\
\hline
\end{tabular}




\section{APÊNDICE 8}

\section{DADOS DOS PACIENTES COM FISSURA}

\begin{tabular}{|c|c|c|c|c|c|c|c|c|c|}
\hline $\mathrm{H} 1$ & $\mathrm{H} 2$ & SAB & BANA & SREP & SEST & AUTOP & $\mathrm{H} 3$ & $\mathrm{HN}$ & SEXO \\
\hline 136 & 146 & 0,0169 & 0 & 0,22 & 0,76 & 5 & 63 & 51 & $\mathrm{~m}$ \\
\hline 59 & 51 & 0,0285 & 0 & 0,12 & 2 & 3 & 58 & 50 & $\mathrm{~m}$ \\
\hline 75 & 53 & 0,0174 & 0 & 0,28 & 0,8 & 7 & 41 & 44 & $\mathrm{~m}$ \\
\hline 44 & 28 & 0,0164 & 0 & 0,32 & 1,6 & 7 & 40 & 53 & $\mathrm{~m}$ \\
\hline 24 & 25 & 0,0037 & 0 & 0,06 & 0,76 & 8 & 22 & 76 & $f$ \\
\hline 43 & 31 & 0,0238 & 0 & 0,01 & 0,3 & 4 & 46 & 20 & $\mathrm{~m}$ \\
\hline 50 & 39 & 0,0128 & 0 & 0,03 & 0,76 & 4 & 48 & 24 & $f$ \\
\hline 114 & 62 & 0,0248 & 0 & 0,03 & 0,72 & 8 & 60 & 45 & $f$ \\
\hline 220 & 68 & 0,0717 & 0 & 0,36 & 4,32 & 4 & 67 & 56 & $\mathrm{~m}$ \\
\hline 285 & 152 & 0,0414 & 0 & 0,44 & 3 & 3 & 69 & 57 & $\mathrm{~m}$ \\
\hline 29 & 27 & 0,0188 & 0 & 0,44 & 1 & 2 & 30 & 36 & $\mathrm{~m}$ \\
\hline 135 & 119 & 0,021 & 0 & 0,05 & 0,72 & 6 & 70 & 57 & $\mathrm{~m}$ \\
\hline 41 & 37 & 0,0131 & 0 & 0,12 & 1,48 & 7 & 31 & 31 & $\mathrm{~m}$ \\
\hline 91 & 54 & 0,0258 & 0 & 0,16 & 1 & 5 & 53 & 40 & $f$ \\
\hline 132 & 227 & 0,0398 & 0 & 0,06 & 0,48 & 0 & 360 & 58 & $f$ \\
\hline 71 & 41 & 0,0407 & 0 & 0,24 & 1,8 & 6 & 49 & 52 & $\mathrm{~m}$ \\
\hline 181 & 36 & 0,0254 & 0 & 0,24 & 0,8 & 8 & 66 & 65 & $f$ \\
\hline 54 & 51 & 0,0073 & 1 & 0,04 & 1,2 & 8 & 72 & 36 & $\mathrm{~m}$ \\
\hline 53 & 50 & 0,0197 & 1 & 0,04 & 0,6 & 4 & 50 & 62 & $\mathrm{~m}$ \\
\hline 27 & 38 & 0,0133 & 0 & 0,12 & 0,68 & 4 & 36 & 35 & $f$ \\
\hline 64 & 54 & 0,0124 & 0 & 0,04 & 1,4 & 5 & 53 & 53 & $f$ \\
\hline
\end{tabular}




\section{Universidade de São Paulo \\ Faculdade de Odontologia de Bauru}

Al. Dr. Octávio Pinheiro Brisolla, 9-75 - Bauru-SP - CEP 17012-901 - C.P. 73

PABX (0XX14)235-8000 - FAX (0XX14)223-4679

Comitê de Ética em Pesquisa

Of. ${ }^{\circ}$ CEP/06 2003/FOB

Bauru, 27 de março de 2003

Senhor Professor,

Informamos que após analise por este Comitê de Etica em Pesquisa em Seres Humanos, seu pedido de alteração do titulo do projeto de pesquisa intitulado "Avaliação dos parâmetros de halitose no paciente fissurado antes e após cirurgia corretiva" de autoria do CD. Flávio Monteiro Amado, sob a sua orientação, para "Avaliação dos parâmetros de halitose bucal e nasal em pacientes com e sem fissura de labio elou palato', foi aprovado considerando que sua metodologia năo sofreu modificações.

Sendo o que nos apresenta para o momento, despedimo-nos,

Atenciosamente,

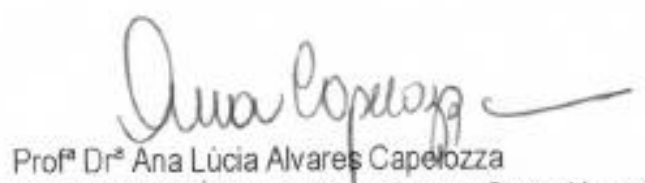

Coordenadora do Comite de Etica em Pesquisa em Seres Humanos

$\| m^{\circ}$ Sr. Prof. Dr. Luiz Eduardo Montenegro Chinellato

DD. Docente do Departamento de Estomatologia 